\title{
Intellectual Property and Human Rights 2.0
}

Peter K. Yu

Texas A\&M University School of Law, peter_yu@msn.com

Follow this and additional works at: https://scholarship.law.tamu.edu/facscholar

Part of the Intellectual Property Law Commons

\section{Recommended Citation}

Peter K. Yu, Intellectual Property and Human Rights 2.0, 53 U. Rich. L. Rev. 1375 (2019).

Available at: https://scholarship.law.tamu.edu/facscholar/1341

This Article is brought to you for free and open access by Texas A\&M Law Scholarship. It has been accepted for inclusion in Faculty Scholarship by an authorized administrator of Texas A\&M Law Scholarship. For more information, please contact aretteen@law.tamu.edu. 


\title{
INTELLECTUAL PROPERTY AND HUMAN RIGHTS 2.0
}

\author{
Peter K. Yu*
}

\begin{abstract}
Written in celebration of the seventieth anniversary of the Universal Declaration of Human Rights, this article calls for greater methodological engagement to refine existing human rights approaches to intellectual property and to devise new approaches to advance the promotion and protection of human rights in the intellectual property area. This article begins by briefly recapturing the past two decades of scholarship on intellectual property and human rights. It documents the progress scholars have made in this intersectional area. The article then draws on the latest research on human rights methods and methodology to explore whether and how we can take the academic discourse to the next level. It highlights three dominant research methods that have been used in this intersectional area: comparative methods, quantitative assessments, and contextual analyses. The second half of this article identifies the contributions a robust discourse on intellectual property and human rights can make to the future development of the intellectual property regime, the human rights regime, and the interface between these two regimes. Responding to critics and skeptics in the intellectual property field, the article concludes by explaining why human rights discussions in the intellectual property area will provide important benefits to the future development of the intellectual property regime, especially in relation to developing countries.
\end{abstract}

* Copyright (C) 2019 Peter K. Yu. Professor of Law, Professor of Communication, and Director, Center for Law and Intellectual Property, Texas A\&M University. This article benefited from discussions with the participants of a number of events at which the author explored issues at the intersection of intellectual property and human rights, including the Annual Meeting of the Norwegian Copyright Society in Oslo, Norway, the Third Business and Human Rights Scholars Conference at Santa Clara University School of Law, the "Global Genes, Local Concerns" Symposium at the University of Copenhagen in Denmark, a workshop organized by the International Centre for Trade and Sustainable Development in Geneva, Switzerland, the 4th International Intellectual Property Scholars Roundtable at Duke University Law School, the International Law Weekend 2014 at Fordham University School of Law, the Workshop on "Patent Regimes and the Right to Science and Culture" at Yale Law School, and the "Intellectual Property and Human Rights" Conference at American University Washington College of Law. The author is grateful to the participants of these events for their valuable comments and suggestions. 


\section{TABLE OF CONTENTS}

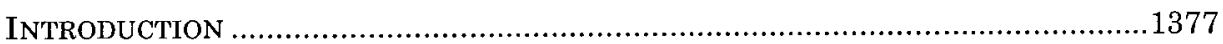

I. INTEllectual PRoperty AND HuMan Rights Scholarship ........................1383

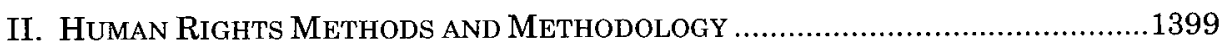

A. Comparative Methods ...................................................................1401

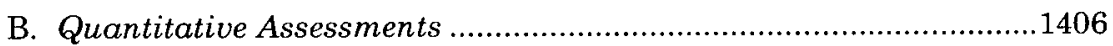

C. Contextual Analyses ...............................................................1416

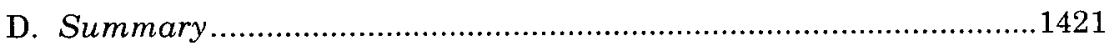

III. Why StUdy InTELlectual PRoperty AND Human Rights?...................... 1424

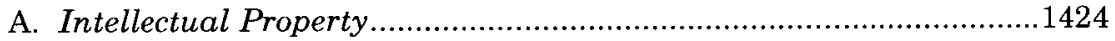

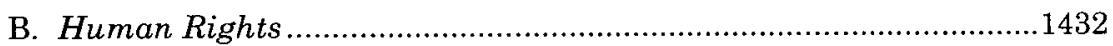

C. Interface Between the Two Regimes............................................1438

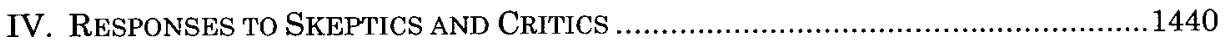

A. Distractions from Internal Improvements .....................................1441

B. Lack of Benefits to Developing Countries .......................................1448

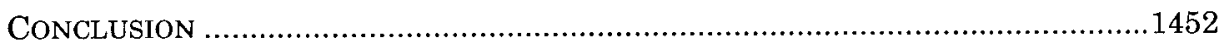




\section{INTRODUCTION}

On December 10, 2018, the Universal Declaration of Human Rights ${ }^{1}$ ("UDHR") reached its seventieth anniversary. To celebrate this historic milestone, the Office of the United Nations High Commissioner for Human Rights ("OHCHR") announced a yearlong series of activities, drawing attention from international organizations, educational institutions, academic commentators, human rights activists, and the public at large. ${ }^{2}$ While most discussions of the UDHR have focused on conventional human rights-such as the prohibition on genocide, slavery, and torture; the rights to freedom of thought, expression, association, and religion; and the rights to life, food, health, basic education, and work-a growing volume of scholarship examines issues lying at the intersection of intellectual property and human rights. ${ }^{3}$

Article 27(2) of the UDHR states that "[e]veryone has the right to the protection of the moral and material interests resulting from any scientific, literary or artistic production of which he [or she] is the author." 4 Although this right has existed for close to seven decades, it did not receive much attention until policymakers and scholars rediscovered the provision about two decades ago. ${ }^{5}$ This rediscovery, or at least rejuvenated emphasis, can be partly attributed to the "Intellectual Property and Human Rights" panel that the World Intellectual Property Organization ("WIPO") organized with the OHCHR in November 1998 to commemorate the fiftieth anniversary of the UDHR. ${ }^{6}$ Shortly after this panel, the United Nations Sub-Commission on the Promotion and Protection of Human Rights ("U.N. Sub-Commission") adopted two resolutions on intellectual property and human rights. ${ }^{7}$

1. G.A. Res. 217 (III) A, Universal Declaration of Human Rights (Dec. 10, 1948) [hereinafter UDHR].

2. See Press Release, Office of the United Nations High Comm'r for Human Rights, New Website Celebrates 70th Anniversary of the Universal Declaration of Human Rights (Nov. 30, 2017), https://www.ohehr.org/EN/NewsEvents/Pages/UDHR70.aspx [https://per ma.cc/W7AU-3XQN].

3. See infra note 20 (collecting book-length treatments in this area).

4. UDHR, supra note 1, art. 27(2).

5. See infra Part I.

6. See World InTellectual Prop. ORg. [WIPO], InTEllectual Property and HuMAN RIGHTS (1999) (providing the proceedings of the "Intellectual Property and Human Rights" panel).

7. Sub-Commission on Human Rights Res. 2001/21, U.N. Doc. E/CN.4/SUB.2/ 
A few years later, the Committee on Economic, Social and Cultural Rights ("CESCR") provided two interpretative comments ${ }^{8}$ on Article 15(1) of the International Covenant on Economic, Social and Cultural Rights ("ICESCR"). ${ }^{9}$ While Article 15(1)(a) covers the right to take part in cultural life, ${ }^{10}$ Article 15(1)(c) focuses on the right to the protection of the moral and material interests resulting from intellectual production. ${ }^{11}$ Both provisions find close parallels in Article 27 of the UDHR. ${ }^{12}$

The only part of Article 15(1) of the UDHR that has not yet received much authoritative interpretation and scholarly attention is Article 15(1)(b), which deals with "the right of everyone ... [t]o enjoy the benefits of scientific progress and its applications." 13 Article 27(1) of the UDHR also recognizes "the right freely ... to share in scientific advancement and its benefits." 14 Even this socalled "right to science"-a right that has been described as being "[t]ucked away at the tail end" of the UDHR and the ICESCR ${ }^{15}$ has now caught the attention of the United Nations Educational,

RES/2001/21 (Aug. 16, 2001) [hereinafter Res. 2001/21]; Sub-Commission on Human Rights Res. 2000/7, U.N. Doc. E/CN.4/Sub.2/RES/2000/7 (Aug. 17, 2000) [hereinafter Res. 2000/7].

8. Comm. on Econ., Soc. \& Cultural Rights, General Comment No. 17: The Right of Everyone to Benefit from the Protection of the Moral and Material Interests Resulting from Any Scientific, Literary or Artistic Production of Which He or She Is the Author (Article 15, Paragraph 1.(c), of the Covenant), U.N. Doc. E/C.12/GC/17 (Jan. 12, 2006) [hereinafter General Comment No. 17]; Comm. on Econ., Soc. \& Cultural Rights, General Comment No. 21: Right of Everyone to Take Part in Cultural Life (Art. 15, Para. 1(a), of the International Covenant on Economic, Social and Cultural Rights), U.N. Doc. E/C.12/GC/21 (Dec. 21, 2009) [hereinafter General Comment No. 21].

9. International Covenant on Economic, Social and Cultural Rights art. 15(1), Dec. 16, 1966, 993 U.N.T.S. 3 [hereinafter ICESCR].

10. Id. art. $15(1)(\mathrm{a})$.

11. Id. art. $15(1)(\mathrm{c})$.

12. Compare id. art. 15(1)(a) (recognizing the right to "take part in cultural life") and id. art. 15(1)(c) (recognizing the right to "benefit from the protection of the moral and material interests resulting from any scientific, literary or artistic production of which he [or she] is the author"), with UDHR, supra note 1, art. 27(1)-(2) (recognizing "the right freely to participate in the cultural life of the community, to enjoy the arts," and "to the protection of the moral and material interests resulting from any scientific, literary or artistic production of which he [or she] is the author").

13. ICESCR, supra note 9, art. 15(1)(b).

14. UDHR, supra note 1 , art. 27(1).

15. William A. Schabas, Study of the Right to Enjoy the Benefits of Scientific and Technological Progress and Its Applications, in HUMAN RIGHTS IN EDUCATION, SCIENCE AND Culture: Legal Developments and Challenges 273, 273 (Yvonne Donders \& Vladimir Volodin eds., 2007) [hereinafter HUMAN RIGHTS IN EDUCATION]. 
Scientific and Cultural Organization ("UNESCO")16 and the Special Rapporteur in the Field of Cultural Rights. ${ }^{17}$

In the past two decades, academic commentators have also paid considerable attention to both the strengths and weaknesses of developing a human rights framework for intellectual property law and policy. ${ }^{18} \mathrm{~A}$ significant volume of literature has now appeared in the area of intellectual property and human rights. For instance, Laurence Helfer and Graeme Austin published a pioneering textbook entitled Human Rights and Intellectual Property: Mapping the Global Interface. ${ }^{19}$ Paul Torremans, Jonathan Griffiths and Uma Suthersanen, Willem Grosheide, and Christophe Geiger also edited important volumes in this hitherto unpopulated area. ${ }^{20}$

16. See U.N. Educ., Sci. \& Cultural Org. [UNESCO], The Right to ENJoy the BENEFITS OF SCIENTIFIC PROGRESS AND ITS APPLICATIONS 3 (2009), https://unesdoc.unesco. org/ark:/48223/pf0000185558 [https://perma.cc/YST9-SUUM] (noting the expert meetings UNESCO organized in Galway, Amsterdam, and Venice in collaboration with human rights and international law organizations).

17. In chronological order, the Special Rapporteur in the Field of Cultural Rights issued the following reports: Farida Shaheed (Special Rapporteur in the Field of Cultural Rights), The Right to Enjoy the Benefits of Scientific Progress and Its Applications, Human Rights Council, U.N. Doc. A/HRC/20/26 (May 14, 2012) [hereinafter Special Rapporteur's Report on the Right to Science]; Farida Shaheed (Special Rapporteur in the Field of Cultural Rights), Copyright Policy and the Right to Science and Culture, Human Rights Council, U.N. Doc. A/HRC/28/57 (Dec. 24, 2014) [hereinafter Special Rapporteur's Report on Copyright Policy]; Farida Shaheed (Special Rapporteur in the Field of Cultural Rights), Cultural Rights, United Nations General Assembly, U.N. Doc. A/70/279 (Aug. 4, 2015) [hereinafter Special Rapporteur's Report on Patent Policy].

18. For discussions of this framework, see Laurence R. Helfer, Toward a Human Rights Framework for Intellectual Property, 40 U.C. DAVIS L. REV. 971 (2007) [hereinafter Helfer, Human Rights Framework]; Peter K. Yu, Reconceptualizing Intellectual Property Interests in a Human Rights Framework, 40 U.C. DAvIS L. REV. 1039 (2007) [hereinafter Yu, Reconceptualizing Intellectual Property Interests]; Peter K. Yu, The Anatomy of the Human Rights Framework for Intellectual Property, 69 SMU L. REV. 37 (2016) [hereinafter Yu, Anatomy].

19. LAURENCE R. HELFER \& GRAEME W. AUSTIN, HuMAN RightS AND INTELLECTUAL PROPERTY: MAPPING THE GLOBAL INTERFACE (2011).

20. These volumes included COPYRIGHT AND FREE SPEECH: COMPARATIVE AND INTERNATIONAL ANALYSES (Jonathan Griffiths \& Uma Suthersanen eds., 2005) [hereinafter COPYRIGHT AND FREE SPEECH]; INTELLECTUAL PROPERTY AND HUMAN RIGHTS: A PARADOX (Willem Grosheide ed., 2010) [hereinafter A PARADOX]; INTELLECTUAL PROPERTY LAW AND HuMAN RIghts (Paul L.C. Torremans ed., 3d ed. 2015) [hereinafter INTELLECTUAL PROPERTy LAW AND Human Rights]; RESEARCH HANDBOOK ON HUMAN RIGHTS AND INTELLECTUAL PROPERTY (Christophe Geiger ed., 2015) [hereinafter RESEARCH HANDBOOK]. 
In addition, scholarship has slowly emerged to cover issues that lend themselves to human rights analyses, such as access to essential medicines, ${ }^{21}$ access to knowledge and educational materials, ${ }^{22}$ and the protection of traditional knowledge and traditional cultural expressions. ${ }^{23}$ Recent scholarship has also gone beyond these well-studied areas to cover new topics, such as Internet-related human rights, ${ }^{24}$ the right to science and culture, ${ }^{25}$ the use of human

21. For discussions of the interplay of human rights and access to medicines, see audrey R. Chapman, Global Health, Human Rights, and the Challenge of NeOliberal Policies (2016); ANGElina SNodgrass Godoy, Of MEdicines and MaRkETS: InTEllectual Property and Human Right's IN THE Free Trade ERA (2013); Helfer \& AUSTIN, supra note 19, at 90-170; HOLGER HESTERMEYER, HUMAN RIGHTS AND THE WTO: The Case of Patents and ACCEss to Medicines (2007); LeE Joo-Young, A Human RIGHTS FRAMEWORK FOR INTELLECTUAL PROPERTY, INNOVATION AND ACCESS TO MEDICINES (2015).

22. For discussions of the interplay of human rights and access to knowledge and educational materials, see HELFER \& AUSTIN, supra note 19, at 316-63; HUMAN RIGHTS IN EDUCATION, supra note 15 . For an excellent collection on the access to knowledge movement, see ACCESS TO KNOWLEDGE IN THE AGE OF INTELLECTUAL PROPERTY (Gaëlle Krikorian \& Amy Kapczynski eds., 2010).

23. For discussions of the interplay of human rights and access to knowledge and educational materials, see Sue Farran, Human Rights Perspective on Protection of Traditional Knowledge and Intellectual Property: A View from Island States in the Pacific, in RESEARCH HANDBOOK, supra note 20, at 641; Susy Frankel, Using Intellectual Property Rules to Support the Self-Determination Goals of Indigenous Peoples, in RESEARCH HANDBOOK, supra note 20, at 627; HELFER \& AUSTIN, supra note 19, at 316-63; MARCELIN TONYE MAHOP, InTEllectual Property, COMMUNITy Rights and HuMAN Rights: THE Biological AND GENETIC RESOURCES OF DEVELOPING COUNTRIES (2010); Rosemary J. Coombe, Intellectual Property, Human Rights \& Sovereignty: New Dilemmas in International Law Posed by the Recognition of Indigenous Knowledge and the Conservation of Biodiversity, 6 IND. J. GLOBAL LEGAL STUD. 59 (1998) [hereinafter Coombe, Intellectual Property]; Rosemary J. Coombe, The Recognition of Indigenous Peoples' and Community Traditional Knowledge in International Law, 14 ST. Thomas L. REV. 275 (2001); Peter K. Yu, Intellectual Property and Human Rights in the Nonmultilateral Era, 64 FLA. L. REV. 1045, 1075-82 (2012) [hereinafter Yu, Nonmultilateral Era]; Yu, Anatomy, supra note 18, at 81-84.

24. For discussions of these issues, see SUSAN PERRY \& ClaUdia RODA, HuMAN RIGHTS and Digital Technology: Digital Tightrope (2017); RESEARCH HaNDBoOK ON HumaN Rights and Digital TEChNOLOGY: Global POLITICS, LAW AND INTERNATIONAL RELATIONS (Ben Wagner et al. eds., 2019) [hereinafter RESEARCH HANDBOOK ON DIGITAL Technology]; Peter K. Yu, Digital Copyright Enforcement Measures and Their Human Rights Threats, in RESEARCH HANDBOOK, supra note 20, at 455 [hereinafter Yu, Digital Copyright Enforcement Measures]; Molly Beutz Land, Protecting Rights Online, 34 YALE J. INT'L L. 1 (2009); Molly Land, Toward an International Law of the Internet, 54 HARV. INT'L L.J. 393 (2013) [hereinafter Land, Toward an International Law].

25. For discussions of this right, see HUMAN RIGHTS IN EDUCATION, supra note 15; INTEllectuAl Property AND ACCESS TO SCIENCE AND CUlTuRE: CoNvergence OR CONFliCt? Global Perspectives and Challenges for the InTEllectual Property System (Christophe Geiger ed., 2016); AURORA Plomer, PATENTS, Human Rights AND ACCESS TO SCIENCE (2015); Elsa Stamatopoulou, CultuRal RightS IN INTERNATIONAL LAW: ARTICLE 27 OF THE UNIVERSAL DECLARATION OF HUMAN RIGHTS AND BEYOND (2007); UNESCO, supra note 16; MARGARET WEIGERS VITULLO \& JESSICA WYNDHAM, AM. ASS'N 
rights impact assessments in the intellectual property area, ${ }^{26}$ the human rights challenges posed by bilateral, regional, and plurilateral trade agreements, ${ }^{27}$ and, most recently, human rights issues implicated by artificial intelligence. ${ }^{28}$

In short, the time is ripe for us to take stock of the past two decades of scholarship on intellectual property and human rights and to closely analyze the progress scholars have made in this intersectional area. It will also be worthwhile to explore ways to upgrade the debate on intellectual property and human rights and to fully engage with the burgeoning literature on human rights research methods and methodology. ${ }^{29}$ After all, despite the ever-growing scholarly literature on intellectual property and human rights, commentators have not devoted much space to articulating the different methods used to conduct research in this area. This article therefore calls for greater methodological engagement to refine ex-

FOR THE ADVANCEMENT OF SCI., DEFINING THE RIGHT TO ENJOY THE BENEFITS OF SCIENTIFIC Progress and ITS APPLiCATIONS: AMERICAN SCIENTISTS' PERSPECTIVES (2013), https:/www.aaas.org/sites/default/files/content_files/UNReportAAAS.pdf [https:/perma.cc ITNL7-EM48]; Lea Shaver, The Right to Science and Culture, 2010 WIS. L. REV. 121; Lea Shaver \& Caterina Sganga, The Right to Take Part in Cultural Life: On Copyright and Human Rights, 27 WIS. INT'L L.J. 637 (2009); Yu, Anatomy, supra note 18.

26. For discussions of these assessments, see Carlos M. Correa, Mitigating the Impact of Intellectual Property in Developing Countries Through the Implementation of Human Rights, in RESEARCH HANDBOOK, supra note 20, at 201, 208-11; JAMES HARRISON, THE HUMAN RIGHTS IMPACT OF THE WORLD TRADE ORGANISATION 226-34 (2007); TODD Landman, Studying Human RIghts 126-39 (2006); SIMON WaLker, The FUTURE of HuMAN RIGHTS IMPACT ASSESSMENTS OF TRADE AGREEMENTS 123-86 (2009); Lisa Forman \& Gillian MacNaughton, Moving Theory into Practice: Human Rights Impact Assessments of Intellectual Property Rights in Trade Agreements, 7 J. HuM. RTS. PRAC. 109 (2015); Yu, Nonmultilateral Era, supra note 23, at 1096-98.

27. For discussions of this impact, see WALKER, supra note 26; Yu, Nonmultilateral Era, supra note 23 , at 1087-91.

28. See, e.g., FUIPPo RAso ET AL., BERKMAN KLEIN CTR. FOR INTERNeT \& SOC'Y, HaRVARD UNIV., ARTIFICIAL INTELligenCE \& HuMAN RIGHTS: OPPORTUNITIES \& RISKS (2018), https://cyber.harvard.edu/sites/default/files/2018-09/2018-09_AIHumanRightsSma ll.pdf [https://perma.cc/NCB5-SP25] (evaluating the human rights impacts of six current uses of artificial intelligence).

29. For this body of scholarship, see LANDMAN, supra note 26; TODD LANDMAN \& EDZIA Carvaluho, Measuring Human RIghts (2010); METHOds of Human Rights ResEarch (Fons Coomans et al. eds., 2009); REsEARCH METHODS IN HuMAN RIGHTS (Lee McConnell \& Rhona Smith eds., 2018); RESEARCH METHOds IN HuMAN Rights: A HANDBOOK (Bård A. Andreassen et al. eds., 2017) (hereinafter RESEARCH METHODS HANDBOOK]. A much earlier work that fits well in this category is HUMAN RIGHTS AND STATISTICS: GETTING THE RECORD STRAIGHT (Thomas B. Jabine \& Richard P. Claude eds., 1992) [hereinafter HuMAN RIGHTS AND STATISTICS]. 
isting human rights approaches to intellectual property and to devise new approaches to advance the promotion and protection of human rights in the intellectual property area. ${ }^{30}$

Part I of this article briefly recaptures the past two decades of scholarship on intellectual property and human rights. This part not only examines the scholarship's evolution and maturation, but also identifies key developments that have enriched scholarship in this area. Part II recognizes that a large part of this past scholarship has focused on drafting history, doctrinal interpretation, and philosophical exploration. This part therefore draws on the latest research on human rights methods and methodology ${ }^{31}$ to explore whether and how we can take the academic discourse to the next level. Specifically, this part highlights three dominant methods that have been used to conduct research on intellectual property and human rights: (1) comparative methods; (2) quantitative assessments; and (3) contextual analyses.

Part III targets the oft-raised question for human rights educators: why do we study human rights in the first place? Instead of answering this broad question, which a growing volume of literature on human rights education has already addressed, ${ }^{32}$ this part narrows the inquiry's focus to the area of intellectual property and

30. For a companion piece that reflects on the different methodological choices I have made in prior works on intellectual property and human rights, see Peter K. Yu, Intellectual Property, Human Rights and Methodological Reflections, in APPROACHES AND METHODOLOGIES IN INTELLECTUAL PROPERTY RESEARCH (Trene Calboli \& Lillà Montagnani eds., forthcoming 2019) [hereinafter Yu, Methodological Reflections].

31. Bard Andreassen, Hans-Otto Sano, and Siobhán McInerney-Lankford noted the difference between "methodology" and "method":

Methodology is the generic term for choice of approach, sometimes connected to theoretical understandings and conceptual paradigms. For instance, the choice between an objectivist and a phenomenological understanding would represent a methodological choice. Method, on the other hand, refers to the specific approach selected, such as quantitative or qualitative methods along with particular analytical tools, such as data generation and analysis. The conceptual hierarchy employed here is, therefore, (a) methodology, (b) methods and (c) tools, where methodology occupies the stage between theoretical understanding and the specific research design.

Bård A. Andreassen et al., Human Rights Research Method, in RESEARCH METHODS HANDBOOK, supra note 29 , at 1, 1-2.

32. For discussions of human rights education, see HUMAN RIGHTS EDUCATION FOR THE TwENTY-FIRST CENTURY (George J. Andreopoulos \& Richard Pierre Claude eds., 1997) [hereinafter HUMAN RIGHTS EDUCATION]; HUMAN RIGHTS EDUCATION: THEORY, RESEARCH, PRAXIS (Monisha Bajaj ed., 2017). 
human rights. This part identifies the contributions a robust discourse in this area can make to the future development of the intellectual property regime, the human rights regime, and the interface between these two regimes. Part IV concludes by responding to critics and skeptics in the intellectual property field, some of whom have found human rights discussions in the intellectual property area distracting, if not unwelcome. This part explains why these discussions, if properly developed, will provide important benefits to the future development of the intellectual property regime, especially in relation to developing countries.

\section{INTELleCtuAl Property AND HUMAN Rights SCHOLARSHIP}

Although the right to the protection of the moral and material interests resulting from intellectual production came into existence with the adoption of the UDHR in December 1948, or even earlier, ${ }^{33}$ this right did not receive much attention until WIPO and the OHCHR organized a panel on November 9, 1998 to commemorate the fiftieth anniversary of the UDHR. ${ }^{34}$ Before this panel, commentators rarely engaged in the debate on intellectual property and human rights, ${ }^{35}$ not to mention a debate on the right to the

33. Article 13 of the American Declaration on the Rights and Duties of Man, which mentions both "inventions" and "literary, scientific or artistic works," predates the UDHR. American Declaration of the Rights and Duties of Man art. 13, May 2, 1948, Hein No. KAV 7225 ("Every person ... has the right to the protection of his moral and material interests as regards his inventions or any literary, scientific or artistic works of which he [or she] is the author.").

34. See WIPO, supra note 6 (providing the panel proceedings).

35. See HELFER \& AUSTIN, supra note 19, at 1 ("Long ignored by both the human rights and intellectual property communities, the relationship between these two fields has now captured the attention of government officials, judges, activist communities, and scholars in domestic legal systems and in international venues....."); Paul L.C. Torremans, Copyright (and Other Intellectual Property Rights) as a Human Right, in INTELLECTUAL PROPERTY LAW AND HUMAN RIGHTS, supra note 20, at 221, 222 [hereinafter Torremans, Copyright] (noting that the intellectual property and human rights disciplines "seemed to stand on [their] own and had very little interest in the development of the other, let alone in the development of any interaction"); Coombe, Intellectual Property, supra note 23, at 60 ("[E]conomic, social, and cultural rights have been juridically marginalized in comparison to civil and political rights, both in terms of the institutional frameworks developed for their implementation and in terms of their judicial interpretation."); Helfer, Human Rights Framework, supra note 18, at 975 ("Until very recently, ... the conceptualization of these intellectual property interests as internationally protected human rights was all but unexplored. Intellectual property has remained a normative backwater in the burgeoning postWorld War II human rights movement, neglected by international tribunals, governments, and legal scholars while other rights emerged from the jurisprudential shadows."); Molly K. Land, The Marrakesh Treaty as "Bottom Up" Lawmaking: Supporting Local Human Rights 
protection of the moral and material interests resulting from intellectual production. ${ }^{36}$ If any discussion took place at all, that discussion tended to focus on a philosophical, rather than positive, conception of human rights. ${ }^{37}$

In retrospect, the timing of the WIPO-OHCHR panel could not have been better. The event was held at a time when policymakers and commentators, especially those in the developing world, were highly critical ${ }^{38}$ of the Agreement on Trade-Related Aspects of Intellectual Property Rights ("TRIPS Agreement") of the World Trade Organization ("WTO"). ${ }^{39}$ Shortly after the panel, the U.N.

Action on IP Policies, 8 U.C. IRVINE L. REV. 513, 517 (2018) [hereinafter Land, Marrakesh Treaty] ("Prior to the mid-1990s, there was little interaction between the intellectual property and human rights regimes."). A rare exception is Ruth L. Gana (Okediji), The Myth of Development, The Progress of Rights: Human Rights to Intellectual Property and Development, 18 LAW \& POL'Y 315, 329 (1996).

36. See Audrey R. Chapman, A Human Rights Perspective on Intellectual Property, Scientific Progress, and Access to the Benefits of Science, in WIPO, supra note 6, at 127, 129 [hereinafter Chapman, Human Rights Perspective] (characterizing article 15 of ICESCR "as the most neglected set of provisions within an international human rights instrument whose norms are not well developed"); Stephen A. Hansen, The Right to Take Part in Cultural Life: Toward Defining Minimum Core Obligations Related to Article 15(1)(a) of the International Covenant on Economic, Social and Cultural Rights, in CORE OBLIGATIONS: BUILDING A FRAMEWORK FOR ECONOMIC, SOCIAL AND CULTURAL RIGHTS 279, 281 (Audrey Chapman \& Sage Russell eds., 2002) [hereinafter CORE OBLIGATIONS] (noting that "cultural rights seem to be among the least understood and developed of all human rights both conceptually and legally, even though they are components of many other human rights as well”); HELFER \& AUSTIN, supra note 19, at 14 ("[T] scientific progress and its applications . . long remained normatively undeveloped even in comparison to other social and economic rights.").

37. See infra text accompanying note 252 (discussing the distinction between the two conceptions).

38. See, e.g., Surendra J. Patel, Can the Intellectual Property Rights System Serve the Interests of Indigenous Knowledge?, in VALUING LOCAL KNOWLEDGE: INDIGENOUS PEOPLE AND INTELLECTUAL PROPERTY RIGHTS 305, 315-16 (Stephen B. Brush \& Doreen Stabinsky eds., 1996) (arguing that the TRIPS Agreement has made the U.S. system of copyright law universal and harms the national interests of the less developed world); Marci A. Hamilton, The TRIPS Agreement: Imperialistic, Outdated, and Overprotective, 29 VAND. J. TRANSNAT'L L. 613,614 (1996) ("Far from being limited to trade relations, correcting the international balance of trade, or lowering customs trade barriers, TRIPS attempts to remake international copyright law in the image of Western copyright law."); A. Samuel Oddi, TRIPSNatural Rights and a "Polite Form of Economic Imperialism," 29 VAND. J. TRANSNAT'L L. 415, 415 (1996) (considering the TRIPS Agreement as a "polite form of economic imperialism"); J.H. Reichman, Intellectual Property in International Trade: Opportunities and Risks of a GATT Connection, 22 VAND. J. TRANSNAT'L L. 747, 813 (1989) ('Imposition of foreign legal standards on unwilling states in the name of 'harmonization' remains today what Ladas deemed it in 1975, namely, a polite form of economic imperialism." (citing 1 STEVEN P. LADAS, PATENTS, TRADEMARKS, AND RELATED RIGHTS: NATIONAL AND INTERNATIONAL PROTECTION 14-15 (1975))).

39. Agreement on Trade-Related Aspects of Intellectual Property Rights, Apr. 15, 1994, Marrakesh Agreement Establishing the World Trade Organization, Annex 1C, 1869 
Sub-Commission adopted two important resolutions on intellectual property and human rights. Resolution 2000/7 declared that "the implementation of the TRIPS Agreement d[id] not adequately reflect the fundamental nature and indivisibility of all human rights." 40 The resolution emphasized "the primacy of human rights obligations over economic policies and agreements." 41 Resolution 2001/21, which was issued a year later, went further to request governments "to take international human rights obligations and principles fully into account in international economic policy formulation" in national, regional, and international economic policy forums. ${ }^{42}$ Also relating to these resolutions was the OHCHR's highly critical report on the TRIPS Agreement. ${ }^{43}$

The WIPO-OHCHR panel was important for another reason. The event was held less than two years before the establishment of the Intergovernmental Committee on Intellectual Property and Genetic Resources, Traditional Knowledge and Folklore. ${ }^{44}$ Created under WIPO's auspices in September 2000, this intergovernmental committee was charged with the development of an international legal instrument, or instruments, for the effective protection of traditional cultural expressions, traditional knowledge, and genetic resources. ${ }^{45}$ Such protection was urgent considering that the draft

U.N.T.S. 299 [hereinafter TRIPS Agreement].

40. Res. 2000/7, supra note 7, II 2; see also David Weissbrodt \& Kell Schoff, Human Rights Approach to Intellectual Property Protection: The Genesis and Application of SubCommission Resolution 2000/7, 5 MinN. INTELL. PROP. ReV. 1 (2003) (discussing the origin, development, and application of Resolution 2000/7).

41. Res. 2000/7, supra note 7, ๆ 3; see also Yu, Reconceptualizing Intellectual Property Interests, supra note 18, at 1092-93 (discussing the principle of human rights primacy).

42. Res. 2001/21, supra note 7, ๆ 3.

43. See U.N. High Commissioner for Human Rights, The Impact of the Agreement on Trade-Related Aspects of Intellectual Property Rights on Human Rights, U.N. Doc. E/CN.4/Sub.2/2001/13 (June 27, 2001) [hereinafter High Commissioner's Report]; see also Yu, Nonmultilateral Era, supra note 23, at 1084-86 (discussing the High Commissioner's Report).

44. See Peter K. Yu, Traditional Knowledge, Intellectual Property, and Indigenous Culture: An Introduction, 11 CARDOZO J. INT'L \& COMP. L. 239, 239-40 (2003); see also HELFER \& AUSTIN, supra note 19, at 432 ("[T] he increased attention given to the rights of indigenous peoples by U.N. agencies in the 1990s was among the catalysts that encouraged international human rights bodies to address intellectual property issues." (footnote omitted)).

45. Intergovernmental Committee (IGC), WIPO, https://www.wipo.int/tk/en/igc/ [https:// perma.cc/F997-J3N9] (last visited Apr. 1, 2019); see also Peter K. Yu, Cultural Relics, Intellectual Property, and Intangible Heritage, 81 TEMP. L. REV. 433, 437 (2008) (discussing the intergovernmental committee). See generally PROTECTING TRADITIONAL KNOWLEDGE: THE WIPo Intergovernmental Committee on Intellectual Property and Genetic RESOURCES, TRADITIONAL KNOWLEDGE AND FolKLORE (Daniel F. Robinson et al. eds., 2017) 
Declaration on the Rights of Indigenous Peoples ${ }^{46}$ had already been released for more than six years.

The year after the WIPO-OHCHR panel, WIPO published the panel proceedings as Publication No. 762. ${ }^{47}$ These proceedings included contributions from noted scholars in both the intellectual property and human rights fields, such as Audrey Chapman, Peter Drahos, and Silke von Lewinski. ${ }^{48} \mathrm{~A}$ few years later, Chapman and Sage Russell put together an excellent volume entitled Core Obligations: Building a Framework for Economic, Social and Cultural Rights. ${ }^{49}$ Although this volume covered a wide variety of economic, social, and cultural rights, its chapters on Article 15(1) of the ICESCR have been particularly instructive. ${ }^{50}$

More directly related to the intellectual property area, Paul Torremans published Copyright and Human Rights: Freedom of Expression-Intellectual Property-Privacy. ${ }^{51}$ This pioneering volume collected papers presented at a conference on "Rights in Information" organized in March 2002 on behalf of the Legal Studies Group of the British Association for Canadian Studies. ${ }^{52}$ A year later, Jonathan Griffiths and Uma Suthersanen published Copyright and Free Speech: Comparative and International Analyses. ${ }^{53}$ Although this edited collection covered an issue that had been widely explored in U.S. copyright law-namely, the tensions and

(collecting articles that offer detailed analyses of the Intergovernmental Committee's effort).

46. G.A. Res. 61/295, Declaration on the Rights of Indigenous Peoples (Sept. 13, 2007) [hereinafter UNDRIP]; see also United Nations Declaration on the Rights of Indigenous Peoples, UNITED NATIONS, https://www.un.org/development/desa/indigenouspeoples/declaration-on-the-rights-of-indigenous-peoples.html [https://perma.cc/V8VL-FNSC] (last visited Apr. 1, 2019) (providing a historical overview of the Declaration).

47. WIPO, supra note 6.

48. See Chapman, Human Rights Perspective, supra note 36, at 127; Peter Drahos, The Universality of Intellectual Property Rights: Origins and Development, in WIPO, supra note 6, at 13; Silke von Lewinski, Intellectual Property, Nationality, and Non-Discrimination, in WIPO, supra note 6 , at 175 .

49. CORE OBLIGATIONS, supra note 36.

50. See Audrey R. Chapman, Core Obligations Related to ICESCR Article 15(1)(c), in CORE OBLigations, supra note 36, at 305; Richard Pierre Claude, Scientists' Rights and the Human Right to the Benefits of Science, in CORE OBLIGATIONS, supra note 36, at 247; Hansen, supra note 36.

51. Copyright AND Human Rights: FREEDOM OF EXPRESSION-INTELlectual PROPERTY-PRIVACY (Paul L.C. Torremans ed., 2004) [hereinafter CopYRIGHT AND HUMAN RIGHTS].

52. Paul L.C. Torremans, Preface to COPYRIGHT AND HUMAN RIGH'T, supra note 51, at vii.

53. Copyright AND Free Speech, supra note 20. 
conflicts between copyright law and the First Amendment ${ }^{54}-$ many chapters explored these tensions and conflicts in human rights terms. ${ }^{55}$

In fall 2003, at a time when the CESCR was busy deliberating the interpretation of Article 15(1)(c) of the ICESCR, Professor Helfer published a widely cited article entitled Human Rights and Intellectual Property: Conflict or Coexistence?56 Drawing on his presentation at the 2003 annual meeting of the Association of American Law Schools, this article foregrounded the then-classic debate on whether intellectual property rights conflict or coexist with human rights. ${ }^{57}$ At the time of the publication, international organizations, policymakers, and commentators remained deeply divided over that particular debate. While those subscribing to the conflict approach viewed the two sets of rights as being in fundamental conflict, ${ }^{58}$ those embracing the coexistence approach considered the two sets of rights essentially compatible. ${ }^{59}$ As Professor Helfer summarized:

54. See Peter K. Yu, The Escalating Copyright Wars, 32 HofSTRA L. REV. 907, 927 n.145 (2004) (collecting sources that discuss the relationship between copyright law and the First Amendment to the U.S. Constitution).

55. See Kevin Garnett, The Impact of the Human Rights Act 1998 on UK Copyright Law, in COPYRIGHT AND FREE SPEECH, supra note 20, at 171 (discussing the impact of the Human Rights Act 1998 on British copyright law and the protection of freedom of expression); Jeremy Phillips, Databases, the Human Rights Act and EU Law, in COPYRIGHT AND FrEE SPEECH, supra note 20, at 401 (discussing sui generis database protection in relation to freedom of expression and freedom of access to information); Uma Suthersanen, Towards an International Public Interest Rule? Human Rights and International Copyright Law, in COPYRIGHT AND FREE SPEECH, supra note 20, at 97 (discussing the contextualization of intellectual property rights within a human rights framework).

56. Laurence R. Helfer, Human Rights and Intellectual Property: Conflict or Coexistence?, 5 MinN. INTELL. PROP. REV. 47 (2003) [hereinafter Helfer, Conflict or Coexistence?].

57. Id.

58. See, e.g., Res. 2001/21, supra note 7, pmbl., recital 11 ("[A]ctual or potential conflict exists between the implementation of the TRIPS Agreement and the realization of economic, social and cultural rights, in particular the rights to self-determination, food, housing, work, health and education, and in relation to transfers of technology to developing countries . . . "); Res. 2000/7, supra note 7, pmbl., recital 11 ("[A]ctual or potential conflicts exist between the implementation of the TRIPS Agreement and the realization of economic, social and cultural rights ....").

59. See, e.g., High Commissioner's Report, supra note 43, ๆ 11 ("The balance between public and private interests found under [the international human rights instruments] is one familiar to intellectual property law."); Secretariat of the World Trade Organization, Protection of Intellectual Property Under the TRIPS Agreement, I 9, U.N. Doc. E/C.12/2000/18 (Nov. 27, 2000) (embracing the coexistence approach and emphasizing the availability of built-in flexibilities in existing international trade agreements). 
The first approach views human rights and intellectual property as being in fundamental conflict. This framing sees strong intellectual property protection as undermining-and therefore as incompatible with-a broad spectrum of human rights obligations, especially in the area of economic, social, and cultural rights. The prescription that proponents of this approach advocate for resolving this conflict is to recognize the normative primacy of human rights law over intellectual property law in areas where specific treaty obligations conflict.

The second approach to the intersection of human rights and intellectual property sees both areas of law as concerned with the same fundamental question: defining the appropriate scope of private monopoly power that gives authors and inventors a sufficient incentive to create and innovate, while ensuring that the consuming public has adequate access to the fruits of their efforts. This school views human rights law and intellectual property law as essentially compatible, although often disagreeing over where to strike the balance between incentives on the one hand and access on the other. ${ }^{60}$

In January 2006, the CESCR finally released General Comment No. 17, a path-breaking document providing an exegesis of the right to the protection of the moral and material interests resulting from intellectual production. ${ }^{61}$ Because the Committee is charged with interpreting provisions in the ICESCR, this authoritative interpretation has provided for many commentators the starting point for analyzing the rights and obligations under Article 15(1)(c). While the length and scope of this article do not allow for a close examination of this interpretive comment, it is worth noting that the general comment has covered in detail the different aspects of the right to the protection of the moral and material interests resulting from intellectual production, including its scope, content, and obligations. ${ }^{62}$

Opening General Comment No. 17 is the statement that this right "derives from the inherent dignity and worth of all persons." 63 The comment's beginning paragraph further states that this right contrasts with "most legal entitlements recognized in intellectual property systems." ${ }^{4}$ As the CESCR elaborated:

Human rights are fundamental, inalienable and universal entitlements belonging to individuals and, under certain circumstances,

60. Helfer, Conflict or Coexistence?, supra note 56, at 48-49 (footnotes omitted); see also Torremans, Copyright, supra note 35, at 222-23 (discussing the two different approaches).

61. General Comment No. 17, supra note 8 .

62. Id.

63. Id. ๆ 1 .

64. Id. 
groups of individuals and communities. Human rights are fundamental as they are inherent to the human person as such, whereas intellectual property rights are first and foremost means by which States seek to provide incentives for inventiveness and creativity, encourage the dissemination of creative and innovative productions, as well as the development of cultural identities, and preserve the integrity of scientific, literary and artistic productions for the benefit of society as a whole.

In contrast to human rights, intellectual property rights are generally of a temporary nature, and can be revoked, licensed or assigned to someone else. While under most intellectual property systems, intellectual property rights, often with the exception of moral rights, may be allocated, limited in time and scope, traded, amended and even forfeited, human rights are timeless expressions of fundamental entitlements of the human person. Whereas the human right to benefit from the protection of the moral and material interests resulting from one's scientific, literary and artistic productions safeguards the personal link between authors and their creations and between peoples, communities, or other groups and their collective cultural heritage, as well as their basic material interests which are necessary to enable authors to enjoy an adequate standard of living, intellectual property regimes primarily protect business and corporate interests and investments. Moreover, the scope of protection of the moral and material interests of the author provided for by article 15, paragraph 1(c), does not necessarily coincide with what is referred to as intellectual property rights under national legislation or international agreements.

It is therefore important not to equate intellectual property rights with the human right recognized in article 15, paragraph 1(c). ${ }^{65}$

Immediately following the release of this interpretive comment, academic commentators utilized it to advance the debate on intellectual property and human rights. ${ }^{66}$ In a symposium on "Intellectual Property and Social Justice" organized by Anupam Chander and Madhavi Sunder and published by the U.C. Davis Law Review, ${ }^{67}$ Professor Helfer called for the adoption of a human rights framework for intellectual property rights. ${ }^{68}$ His article carefully analyzed General Comment No. $17^{69}$ while offering insights into

65. Id. ๆ 1-3 (footnote omitted).

66. See, e.g., HELFER \& AUSTIN, supra note 19, at 172 (describing General Comment No. 17 as "a key point of reference for analysis of the normative content of Article 15(1)(c)" of the ICESCR).

67. See Anupam Chander \& Madhavi Sunder, Is Nozick Kicking Rawls's Ass-Intellectual Property and Social Justice, 40 U.C. DAVIS L. REV. 563 (2007) (providing an introduction to this symposium).

68. Helfer, Human Rights Framework, supra note 18.

69. See id. at 987-1001 (discussing the CESCR's approach to interpreting Article $15(1)(\mathrm{c})$ of the ICESCR). 
three possible futures of this framework. ${ }^{70}$ Picking up on where Professor Helfer left off, I revisited the drafting history of both the UDHR and the ICESCR ${ }^{71}$ and outlined the different approaches that could be used to determine which forms or aspects of intellectual property rights are supported by international and regional human rights instruments. ${ }^{72}$ That article also responded to those criticizing the ongoing efforts to engage in a human rights discourse in the intellectual property area. ${ }^{73}$ Also appearing in the U.C. Davis symposium was Kal Raustiala's cautious critique of the human rights approach to intellectual property. ${ }^{74}$ In his view, "the embrace of IP [intellectual property] by human rights advocates and entities ... is likely to further entrench some dangerous ideas about property: in particular, that property rights as human rights ought to be inviolable and ought to receive extremely solicitous attention from the international community."75

Although the articles in this symposium took a rather cautious approach to examining the interplay of intellectual property and human rights, an emerging strand of commentary appeared to elevate the status of intellectual property rights to that of human rights. ${ }^{76}$ While this body of work mentioned the right to the protection of the moral and material interests resulting from intellectual

70. See id. at 1014-20 (discussing three possible futures of this framework: (1) "Using Human Rights to Expand Intellectual Property"; (2) "Using Human Rights to Impose External Limits on Intellectual Property"; and (3) "Achieving Human Rights Ends Through Intellectual Property Means").

71. See Yu, Reconceptualizing Intellectual Property Interests, supra note 18, at 104775. For detailed histories of the drafting of the UDHR, see MARY ANN GLENDON, A WORLD

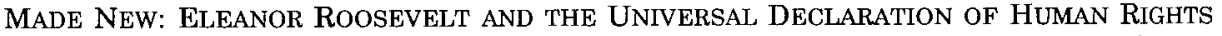
(2001); John P. Humphrey, Human Rights and THE UNITED Nations: A GReAT AdVENTURE (1984); M. GLEN JOHNSON \& JANUSZ SyMONIDES, THE UNIVERSAL DECLARATION OF HUMAN RIGHTS: A HISTORY OF ITS CREATION AND IMPLEMENTATION, 19481998 (1998); JOHANNES MORSINK, THE UNIVERSAL DEClaARTION OF HUMAN RightS: ORIGINS, DRAFTING, AND INTENT (1999).

72. See Yu, Reconceptualizing Intellectual Property Interests, supra note 18, at 10751123.

73. See id. at $1123-48$.

74. Kal Raustiala, Density and Conflict in International Intellectual Property Law, 40 U.C. DAVIS L. REV. 1021 (2007).

75. Id. at 1032; see also HELFER \& AUSTIN, supra note 19, at 504-05 ("Some in the human rights community ... fear that intellectual property owners-in particular, multinational corporations-will invoke the creators' rights and property rights provisions of international instruments to lock in maximalist intellectual property rules that will further concentrate wealth in the hands of a few at the expense of the many.").

76. See, e.g., Tom Giovanetti \& Merrill Matthews, Inst. for Policy Innovation, Intellectual Property Rights and Human Rights, IDEAS (Inst. for Policy Innovation, Dallas, Tex.), 
production, it also used the right to private property to provide an alternative human rights basis for intellectual property rights. ${ }^{77}$ At times, this body of work elided the important distinctions between tangible and intangible property, thereby deemphasizing the nonrivalrous and nonexcludable nature of intellectual property. ${ }^{78}$ Until the arrival of this body of "intellectual property as human rights" commentary, most scholarship in this area covered the

Sept. 2005, https://www.ipi.org/docLib/IPandHumanRights.pdf-OpenElement.pdf [https:// perma.cc/928L-A6DA] ("IP protection has long been recognized as a basic human right .... [E]xpropriation of others' property not only undermines creation and invention, it also undermines economies and societies. It is, ironically, one of the most 'anti-human rights' actions governments could take.").

77. See Charter of Fundamental Rights of the European Union art. 17(2), Dec. 7, 2000, 2000 O.J. (C 364) 1 ("Intellectual property shall be protected."); Protocol to the Convention for the Protection of Human Rights and Fundamental Freedoms art. 1, Mar. 20, 1952, 213 U.N.T.S. 262 ("Every natural or legal person is entitled to the peaceful enjoyment of his possessions. No one shall be deprived of his possessions except in the public interest and subject to the conditions provided for by law and by the general principles of international law."); Special Rapporteur's Report on Copyright Policy, supra note 17, ๆ52 ("An alternative human rights basis for intellectual property protection is recognized through the lens of the right to property in the European regional human rights system, as well as in some national constitutions both within and outside Europe."); HELFER \& AUSTIN, supra note 19, at 510 ("Seizing upon (and often misreading) the creators' rights and property rights clauses of international instruments, [intellectual property] industries seek to lock in maximalist intellectual property protection by invoking the rhetoric of human rights as trumps."); Robert L. Ostergard, Jr., Intellectual Property: A Universal Human Right?, 21 HUM. RTS. Q. 156, 175 (1999) ("The basis for [the designation of intellectual property as a universal human right] without doubt lies in the Western conception of property rights."). But cf. Jan Brinkhof, On Patents and Human Rights, in A PARADOX, supra note 20, at 140, 146 (illustrating the need to clarify the human rights basis of intellectual property rights by differentiating between "a human right to a bicycle" and "an entitlement in human rights law to the protection of my property in the bicycle that I own"); Jakob Cornides, Human Rights and Intellectual Property: Conflict or Convergence, 7 J. WORLD INTELL. PROP. 135, 146 (2004) (questioning "whether intellectual property corresponds to the classic concept of property-i.e., a plenary and unlimited right to possess, use, exploit or destroy something, or to grant or deny access to it-or whether it is a sui generis right fulfilling a different purpose"); $\mathrm{Yu}$, Reconceptualizing Intellectual Property Interests, supra note 18, at 1128-29 (stating that the right to the protection of the moral and material interests resulting from intellectual production "was not designed to protect the unqualified property-based interests in intellectual creations, but rather to protect the narrow interest of just remuneration for intellectual labor"); Yu, Anatomy, supra note 18, at 88-89 (noting that a property-based regime "does not provide adequate protection to the moral interests resulting from intellectual productions, such as those protected through moral rights or other non-economic rights"). See generally OLE-

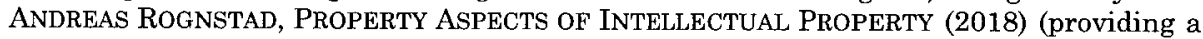
recently published and excellent discussion of the property aspects of intellectual property rights).

78. For discussions of the distinctions between real property and intellectual property, see Mark A. Lemley, Property, Intellectual Property, and Free Riding, 83 TEx. L. REv. 1031 (2005); Stewart E. Sterk, Intellectualizing Property: The Tenuous Connections Between Land and Copyright, 83 WASH. U. L.Q. 417 (2005). See also Peter K. Yu, Intellectual Property and the Information Ecosystem, 2005 MicH. ST. L. REV. 1, 1-6 (discussing the controversy over the term "intellectual property"). 
interrelationship between intellectual property and human rights and the human rights limits to intellectual property rights. ${ }^{79}$

A decade and a half ago, a number of important international and regional developments began to impact the debate on intellectual property and human rights. In September 2007, the Declaration on the Rights of Indigenous Peoples was finally adopted after appearing in draft form for more than a decade. ${ }^{80}$ This Declaration is particularly important to the ongoing efforts to strengthen protection for traditional knowledge and traditional cultural expressions. Article 31(1) of the Declaration specifically provides:

Indigenous peoples have the right to maintain, control, protect and develop their cultural heritage, traditional knowledge and traditional cultural expressions, as well as the manifestations of their sciences, technologies and cultures, including human and genetic resources, seeds, medicines, knowledge of the properties of fauna and flora, oral traditions, literatures, designs, sports and traditional games and visual and performing arts. They also have the right to maintain, control, protect and develop their intellectual property over such cultural heritage, traditional knowledge, and traditional cultural expressions. ${ }^{81}$

Two years later, the CESCR released General Comment No. 21, its second authoritative interpretation of Article 15(1) of the ICESCR. ${ }^{82}$ This time, the comment focused on the right to take part in cultural life, as provided in Article 15(1)(a). ${ }^{83}$ With the issuance of this interpretive comment, the only portion of Article 15(1) that the CESCR has not yet interpreted is the one concerning "the right ... [t]o enjoy the benefits of scientific progress and its applications." 84

In the past decade, even this so-called "right to science" has received growing attention following the expert meetings put together by UNESCO and several human rights and international

79. See Yu, Anatomy, supra note 18, at 44 ("In the past two decades, commentators have participated in the debate on intellectual property and human rights (including the debate on the human rights limits to intellectual property rights). Beginning in the late 1990s, they have also begun engaging in the debate on intellectual property as human rights." (footnote omitted)).

80. UNDRIP, supra note 46.

81. Id. art. 31(1).

82. General Comment No. 21, supra note 8 .

83. ICESCR, supra note 9, art. 15(1)(a).

84. Id. art. $15(1)$ (b). 
law organizations. ${ }^{85}$ These meetings culminated in the adoption of the Venice Statement on the Right to Enjoy the Benefits of Scientific Progress and Its Application in July 2009. ${ }^{86}$ Three years later, the first Special Rapporteur in the Field of Cultural Rights, Farida Shaheed, issued a report on the right to science. ${ }^{87}$ This report was quickly followed by a report examining the human rights impact of copyright policy on the protection of this right ${ }^{88}$ and another report on a similar impact in the patent area. ${ }^{89}$

In November 2008, the World Blind Union, other nongovernmental organizations, and supportive governments in the developing world began to push for what eventually became the Marrakesh Treaty to Facilitate Access to Published Works for Persons Who Are Blind, Visually Impaired or Otherwise Print Disabled ("Marrakesh Treaty"). ${ }^{90}$ Aiming to provide individuals with print

85. See UNESCO, supra note 16, at 3 (noting the expert meetings in Venice, Amsterdam, and Galway).

86. See id. at $13-20$.

87. Special Rapporteur's Report on the Right to Science, supra note 17.

88. Special Rapporteur's Report on Copyright Policy, supra note 17.

89. Special Rapporteur's Report on Patent Policy, supra note 17.

90. Marrakesh Treaty to Facilitate Access to Published Works for Persons Who Are Blind, Visually Impaired or Otherwise Print Disabled, June 27, 2013, 52 I.L.M. 1312 [hereinafter Marrakesh Treaty]. As James Love recounted:

The idea for the treaty was first proposed by a WIPO/UNESCO consultant Wanda Noel in 1985, but did not move in WIPO until the World Blind Union ... and other [non-governmental organizations] including [Knowledge Ecology International] proposed a draft treaty to WIPO in November 2008. In May 2009 Brazil, Ecuador and Paraguay formally introduced the treaty text where it first $\mathrm{m}[\mathrm{e}] \mathrm{t}$ stiff opposition from the United States and the European Union.

James Love, KEI Statement on WIPO Decision to Hold June 2013 Diplomatic Conference for Treaty on Copyright Exceptions for Disabilities, KNOWLEDGE ECOLOGY INT'L (Dec. 18, 2012), https://www.keionline.org/22098 [https:/perma.cc/DS6E-SH28]. See generally LAURENCE R. HelfER ET AL., THE WORLD BLIND UNION GUIDE TO THE MARRAKESH TREATY: FACLITATING ACCESS TO BOOKS FOR PRINT-DISABLED INDIVIDUALS (2017) (providing a detailed commentary on the Marrakesh Treaty). Molly Land noted the Treaty's key human rights contributions:

The Marrakesh Treaty . . lays a foundation for better translation of intellectual property issues into human rights advocacy on the domestic level. It does this in two ways: first, by identifying a clear violation (for example, a "book famine" for individuals with disabilities) that can be attributed to the effects of intellectual property rules (needing a license from the copyright owner in each country in order to create an accessible version of a book), and second, by activating domestic human rights advocates, naming them as explicit partners in intellectual property policy making and implementation on the domestic level.

Land, Marrakesh Treaty, supra note 35, at 515 (footnote omitted). 
disabilities with easy or ready access to copyrighted publications, and to address what has been referred to as "the global book famine,"91 the treaty was adopted on June 27, 2013 and entered into force on September 30, 2016. Recital 1 of the preamble of the Marrakesh Treaty specifically recalled "the principles of non-discrimination, equal opportunity, accessibility and full and effective participation and inclusion in society, proclaimed in the Universal Declaration of Human Rights and the United Nations Convention on the Rights of Persons with Disabilities." 92 Such preambular language marked the first time a WIPO agreement explicitly referred to obligations in an international human rights instrument. ${ }^{93}$ In the view of Ahmed Abdel-Latif, "[this treaty], by responding to the needs of a special category of users and consumers, and facilitating their access to knowledge[,] contributes to the realization of the [right to development] in terms of inclusive participation in decision-making processes and the achievement of social justice in development."94

At the regional level, the past decade has seen courts in Europe handing down important decisions in the area of intellectual property and human rights. The two most widely cited cases were Ashdown v. Telegraph Group Ltd. before the Court of Appeals of England and Wales ${ }^{95}$ and Anheuser-Busch Inc. v. Portugal before the

91. WIPO, The Marrakesh TReaty-Helping to End the Global Book Famine 2 (2016), https://www.wipo.int/edocs/pubdocs/en/wipo_pub_marrakesh_overview.pdf [https:// perma.cc/59N9-M67P].

92. Marrakesh Treaty, supra note 90, pmbl., recital 1.

93. As Ahmed Abdel-Latif observed:

This treaty marks a double precedent in WIPO's recent history. First, a WIPO

Treaty is solely devoted, for the first time, to limitations and exceptions addressing the needs of a specific category of users and consumers rather than right holders. Second, it is the first international IP treaty to make reference to human rights instruments.

Ahmed Abdel-Latif, The Right to Development: What Implications for the Multilateral Intellectual Property Framework?, in RESEARCH HANDBOoK, supra note 20, at 605, 624. The World Blind Union Guide concurred:

[The Marrakesh Treaty] is the first international legal instrument whose principal aim is to establish mandatory exceptions to the exclusive rights of copyright owmers. It also marks the first time that the realization of international human rights has been the explicit objective of a [WIPO] treaty and of the international system for the protection of intellectual property.

HELFER ET AL., supra note 90, at 91.

94. Abdel-Latif, supra note 93 , at 624 .

95. Ashdown v. Tel. Grp., Ltd., [2001] EWCA (Civ) 1142, [2002] Ch [149] (Eng.) (balancing copyright protection against the protection of freedom of expression in a case involving the newspaper's publication of a yet-to-be-published minute regarding a post-election 
European Court of Human Rights ("ECtHR"). ${ }^{96}$ In an important article, Professor Helfer discussed not only Anheuser-Busch, but also several other ECtHR cases that scholars have understudied or overlooked. ${ }^{97}$ Since then, that court-and, to a lesser extent, the Court of Justice of the European Union-has undertaken greater efforts to balance the protection of intellectual property rights with that of fundamental rights. ${ }^{98}$ Such balancing is particularly salient in cases involving Internet intermediaries, which implicate not only the users' freedom of expression but also the intermediaries' freedom to conduct a business, a fundamental right recognized by Article 16 of the Charter of Fundamental Rights of the European Union. ${ }^{99}$

Apart from all of these human rights-related developments, the European Union, the United States, and other developed or likeminded countries have also been actively negotiating plurilateral

secret meeting between Paddy Ashdown and Prime Minister Tony Blair). For discussions of this case, see Michael D. Birnhack, Acknowledging the Conflict Between Copyright Law and Freedom of Expression Under the Human Rights Act, 14 ENT. L. REV. 24 (2003); Garnett, supra note 55.

96. Anheuser-Busch Inc. v. Portugal, 45 Eur. Ct. H.R. 36 (2007) (Grand Chamber).

97. Laurence R. Helfer, The New Innovation Frontier? Intellectual Property and the European Court of Human Rights, 49 HARV. IN'T'L L.J. 1. (2008).

98. See Henning Grosse Ruse-Khan, Overlaps and Conflict Norms in Human Rights Law: Approaches of European Courts to Address Intersections with Intellectual Property Rights, in RESEARCH HANDBOOK, supra note 20, at 70, 71-78 (discussing the three leading cases decided by the Court of Justice of the European Union that applied the right to property under the Charter of Fundamental Rights of the European Union); Laurence R. Helfer, Mapping the Interface Between Human Rights and Intellectual Property, in RESEARCH HANDBOOK, supra note 20, at 6, 7-8 [hereinafter Helfer, Mapping the Interface] (highlighting the two important recent judgments of the European Court of Human Rights); Tuomas Mylly, The Constitutionalization of the European Legal Order: Impact of Human Rights on Intellectual Property in the EU, in RESEARCH HANDBOOK, supra note 20, at 103, 107-26 (tracing the evolution of the case law handed down by the Court of Justice of the European Union concerning the interface between fundamental rights and intellectual property rights).

99. See Charter of Fundamental Rights of the European Union art. 16, Dec. 7, 2000, 2012 O.J. (C 326) 391 ("The freedom to conduct a business in accordance with Union law and national laws and practices is recognised."). 
trade agreements. ${ }^{100}$ Because these agreements are being negotiated in nontransparent processes ${ }^{101}$ that aimed to establish clubbased memberships, ${ }^{102}$ they have raised serious concerns about both human rights protection and the promotion of the rule of law. ${ }^{103}$ Among the more controversial plurilateral agreements are the Anti-Counterfeiting Trade Agreement ${ }^{104}$ and the Trans-Pacific Partnership ("TPP") Agreement. ${ }^{105}$ Following the United States'

100. See generally INTELLECTUAL PROPERTY AND FREE TRADE AGREEMENTS (Christopher Heath \& Anselm Kamperman Sanders eds., 2007) (collecting essays that discuss free trade agreements in the intellectual property context); Peter K. Yu, The Non-Multilateral Approach to International Intellectual Property Normsetting, in INTERNATIONAL INTELLECTUAL PROPERTY: A HANDBOOK OF CONTEMPORARY RESEARCH 83 (Daniel J. Gervais ed., 2015) (discussing TRIPS-plus bilateral, regional, and plurilateral trade agreements).

101. For discussions of the lack of transparency in the negotiations for the Anti-Counterfeiting Trade Agreement, see David S. Levine, Bring in the Nerds: Secrecy, National Security and the Creation of International Intellectual Property Law, 30 CARDOZO ARTS \& ENT. L.J. 105 (2012); David S. Levine, Transparency Soup: The ACTA Negotiating Process and "Black Box" Lawmaking, 26 AM. U. INT'L L. REV. 811 (2011); Peter K. Yu, Six Secret (and Now Open) Fears of ACTA, 64 SMU L. REV. 975, 998-1019 (2011) Thereinafter Yu, Six Secret Fears].

102. For discussions of club-based memberships in relation to the Anti-Counterfeiting Trade Agreement and the Trans-Pacific Partnership, see Daniel Gervais, Country Clubs, Empiricism, Blogs and Innovation: The Future of International Intellectual Property Norm Making in the Wake of ACTA, in TRADE GOVERNANCE IN THE DIGITAL AGE: WORLD TRADE FORUM 323 (Mira Burri \& Thomas Cottier eds., 2012); Peter K. Yu, The ACTA/TPP Country Clubs, in ACCESS TO INFORMATION AND KNOWLEDGE: 21ST CENTURY CHALLENGES IN INTELLECTUAL PROPERTY AND KNOWLEDGE GOVERNANCE 258 (Dana Beldiman ed., 2013) [hereinafter Yu, ACTA/TPP Country Clubs].

103. See General Comment No. 17, supra note 8, ๆ 34 ("The obligation to fulfil (promote) requires States parties to ensure the right of authors of scientific, literary and artistic productions to take part in the conduct of public affairs and in any significant decision-making processes that have an impact on their rights and legitimate interests ...."); Special Rapporteur's Report on Copyright Policy, supra note 17, I 92 ("International intellectual property instruments, including trade agreements, should be negotiated in a transparent way, permitting public engagement and commentary."); Special Rapporteur's Report on Patent Policy, supra note 17, 1 ๆ 73-76 (noting the importance of public participation and transparency in intellectual property policymaking in bilateral and multilateral fora); HELFER \& AUSTIN, supra note 19, at 512-13 (noting that "the process, transparency, and predictability values ... are hallmarks of the rule of law" and that "the connection between human rights and the rule of law is well established [today] and provides additional arguments for contesting intellectual property initiatives that conflict with rule of law values" (footnote omitted)); Rhona Smith, Human Rights Based Approaches to Research, in RESEARCH METHODS IN HUMAN RIGHTS, supra note 29, at 6, 7 ("[A] human rights based approach will focus on not only the outcome ... . but how that outcome is achieved (coordination with stakeholders, both duty bearers and rights holders).").

104. Anti-Counterfeiting Trade Agreement, opened for signature May 1, 2011, 50 I.L.M. 243 (2011). For this author's discussions of ACTA, see Yu, ACTA/TPP Country Clubs, supra note 102; Peter K. Yu, ACTA and Its Complex Politics, 3 WIPO J. 1 (2011); Peter K. Yu, Enforcement, Enforcement, What Enforcement?, 52 IDEA INTELL. PROP. L. REV. 239 (2012); Yu, Six Secret Fears, supra note 101.

105. Trans-Pacific Partnership Agreement, Feb. 4, 2016, https://ustr.gov/trade-agree 
withdrawal from the TPP, ${ }^{106}$ the latter instrument has been replaced by the Comprehensive and Progressive Agreement for Trans-Pacific Partnership ("CPTPP"). ${ }^{107}$ In response to the TPP/CPTPP negotiations, China, India, and other Asian developing countries have also championed the development of their own plurilateral initiative, the Regional Comprehensive Economic Partnership ("RCEP"). ${ }^{108}$

Finally, in the academic circle, a growing number of commentators have explored issues lying at the intersection of intellectual property and human rights. In 2007, Holger Hestermeyer published an important book covering the intersection of human rights, international trade, and access to medicine. ${ }^{109}$ This book highlighted an important and unique challenge:

ments/free-trade-agreements/trans-pacific-partnership/tpp-full-text [https://perma.cc/TZ32 -3F6T]. For this author's discussions of the TPP, see Yu, ACTA/TPP Country Clubs, supra note 102; Peter K. Yu, TPP, RCEP, and the Crossvergence of Asian Intellectual Property Standards, in GOVERNING SCIENCE AND TECHNOLOGY UNDER THE INTERNATIONAL ECONOMIC ORDER: REgUlatory DIVERGENCE AND CONVERgENCE IN THE AgE OF MEgaregionals 277 (Peng Shin-yi et al. eds., 2018) [hereinafter Yu, TPP, RCEP, and Crossvergence]; Peter K. Yu, TPP, RCEP and the Future of Copyright Norm-Setting in the Asian Pacific, in MAKING COPYRIGHT WORK FOR THE ASIAN PACIFIC? JUXTAPOSING HARMONISATION WITH FLEXIBILITY 19 (Susan Corbett \& Jessica C. Lai eds., 2018) [hereinafter Yu, TPP, RCEP and Copyright Normsetting]; Peter K. Yu, Thinking About the TransPacific Partnership (and a Mega-Regional Agreement on Life Support), 20 SMU SCI. \& TECH. L. REv. 97 (2017) [hereinafter Yu, Thinking About TPP]; Peter K. Yu, TPPand Trans-Pacific Perplexities, 37 FORDHAM INT'L L.J. 1129 (2014).

106. See Yu, Thinking About TPP, supra note 105, at 101-10 (discussing the United States' withdrawal from the partnership and its aftermath).

107. Comprehensive and Progressive Agreement for Trans-Pacific Partnership, Mar. 8, 2018, http://dfat.gov.au/trade/agreements/not-yet-in-force/tpp-11/official-documents/Docu ments/tpp-11-treaty-text.pdf [https://perma.cc/RL5Z-AGWL]; see also Yu, Thinking About TPP, supra note 105, at 104-06 (discussing the CPTPP); CPTPP us. TPP, N.Z. MiNISTRY FOREIGN AFF. \& TRADE, https://www.mfat.govt.nz/en/trade/free-trade-agreements/agreem ents-under-negotiation/cptpp-2/tpp-and-cptpp-the-differences-explained/ [https://perma. cc/52VM-XX8D] (last visited Apr. 1, 2019) (explaining the differences between the TPP and the CPTPP).

108. ASEAN Plus Six, Joint Declaration on the Launch of Negotiations for the Regional Comprehensive Economic Partnership (Nov. 20, 2012), https://dfat.gov.au/trade/agree ments/negotiations/rcep/news/Documents/joint-declaration-on-the-launch-of-negotiationsfor-the-regional-comprehensive-economic-partnership.pdf [https://perma.cc/W36P-XB4R] (launching the negotiations on the RCEP). For this author's discussions of the RCEP, see Peter K. Yu, The RCEP and Trans-Pacific Intellectual Property Norms, 50 VAND. J. TRANSNAT'L L. 673 (2017); Peter K. Yu, The RCEP Negotiations and Asian Intellectual Property Norm Setters, in ThE Future of ASIAN TRADE DEALS AND INTELlectual ProperTy (Liu Kung-Chung \& Julien Chaisse eds., forthcoming 2019); Yu, TPP, RCEP, and Crossvergence, supra note 105; Yu, TPP, RCEP and Copyright Normsetting, supra note 105.

109. HESTERMEYER, supra note 21. 
What makes [the conflict between the TRIPS Agreement and human rights] particularly problematic is that [these] rights, while not in general legally on a higher normative level, at least have a higher normative appeal than WTO law. However, its strong enforcement system puts WTO law on a higher level in a factual hierarchy of regimes, so that ultimately state behaviour will largely be determined by the solution found within the WTO regime. ${ }^{110}$

A year later, Paul Torremans expanded his collection of essays from copyright and related issues to cover all forms of intellectual property rights. ${ }^{111}$ That collection entered its third edition in 2015 and is now on its way to a fourth edition. ${ }^{112}$ Willem Grosheide also published Intellectual Property and Human Rights: A Paradox. ${ }^{113}$ This edited volume collected papers presented at a conference celebrating the twentieth anniversary of the Centre for Intellectual Property Law of the Molengraaff Institute for Private Law at Utrecht University in the Netherlands. ${ }^{114}$

As if these publications were not enough, Laurence Helfer and Graeme Austin published a pioneering textbook entitled Human Rights and Intellectual Property: Mapping the Global Interface. ${ }^{115}$ This 2011 book is the first student text written in this highly specialized area. Before its publication, professors interested in teaching a course on intellectual property and human rights had to put together their own reading materials. ${ }^{116}$ A few years later, Christophe Geiger also put together an excellent Research Handbook on Human Rights and Intellectual Property. ${ }^{117}$ With thirty-five chapters, this comprehensive volume collected papers presented at the Fifteenth European Intellectual Property Institutes Network ("EIPIN") Congress on "Human Rights and Intellectual Property: From Concepts to Practice."118 Held at the Court of European Human Rights in Strasbourg, the event was organized by the Centre

110. Id. at $\mathrm{xxxv}$.

111. Intellectual Property and Human Rights (Paul L.C. Torremans ed., expanded ed. 2008).

112. Intellectual PROPERTy LAW AND Human Rights, supra note 20; INTELlectual Property LaW AND Human Rights (Paul L.C. Torremans ed., 4th ed. forthcoming 2020).

113. A PARADOX, supra note 20.

114. Willem Grosheide, Preface to A PARADOX, supra note 20, at ix, ix.

115. HELFER \& AUSTIN, supra note 19.

116. See id. at xv ("Partly because of the novelty of the topic, no teaching materials existed, a gap that endures today.").

117. RESEARCH HANDBOOK, supra note 20.

118. Christophe Geiger, Introduction to RESEARCH HANDBOOK, supra note 20, at 1, 4. 
for International Intellectual Property Studies at the University of Strasbourg. ${ }^{119}$

Apart from books and scholarly articles examining the more traditional issues at the intersection of intellectual property and human rights, commentators have begun to tackle new topics. These topics include Internet-related human rights, the right to science and culture, the use of human rights impact assessments in the intellectual property area, the human rights challenges posed by bilateral, regional, and plurilateral trade agreements, and, most recently, human rights issues implicated by artificial intelligence. ${ }^{120}$ Thus, the linkage of intellectual property and human rights has not only brought new perspectives to the intellectual property debate, but has also invited intellectual property scholars to examine existing and new topics through a human rights lens.

In sum, although the field of intellectual property and human rights was pretty nascent when the UDHR reached its fiftieth anniversary, it has since been greatly enriched by new human rights decisions and documents, a growing volume of scholarship at the intersection of intellectual property and human rights, and a plethora of new issues that deserve attention from scholars undertaking research in this intersectional area. The time is therefore ripe for us to explore how we can further advance the scholarly debate in this area.

\section{Human Rights Methods AND Methodology}

In light of the myriad developments in the area of intellectual property and human rights in the past two decades, one has to wonder what other issues and perspectives can be examined to advance research in this area. While scholars will undoubtedly develop new theories, analyses, and perspectives, this part calls for greater attention to the methods and methodology used to conduct research in this area.

A greater methodological engagement is imperative for three reasons. First, despite the growing volume of scholarship on intel-

119. Id.

120. See supra notes 24-28 (collecting sources that provide discussions in these areas). 
lectual property and human rights, commentators have not devoted much space to articulating the different methods used in this body of scholarship (even though some scholarship in this area has revealed careful and thoughtful methodological choices). ${ }^{121}$ As analysis on intellectual property and human rights becomes more systematic, and in view of the groundwork that has already been laid, it is time we identified and explored in greater depth the methods and methodology used to conduct research in this area. Second, the past few years have seen a growing volume of literature examining human rights methods and methodology. ${ }^{122}$ The time is ripe for intellectual property and human rights scholarship to take a methodological turn to further engage with this emerging body of work. ${ }^{123}$ Third, whether researchers admit it or not, the choice of methods tends to affect the outcome of their analyses. ${ }^{124}$ A deeper understanding of the research tools, models, and methods used will therefore enable them to better understand the strengths, limitations, and potential biases of their approaches.

Although the length and scope of this article do not allow for a detailed discussion of the different methods used in human rights research, this part highlights three dominant methodological choices: (1) comparative methods; (2) quantitative assessments;

121. See Eva Brems, Methods in Legal Human Rights Research, in METHODS OF HUMAN RIGHTS RESEARCH, supra note 29 , at 77, 84 ("It is one thing to use a method, it is another thing to reflect upon it and it is yet another thing to report on the method you used in your published research.").

122. See supra note 29 (collecting sources that discuss this growing volume of literature).

123. See Fons Coomans et al., A Primer, in METhods of Human Rights Research, $s u$ pra note 29 , at 11,12 ("ח]f there is indeed a methodological deficit in human rights scholarship it is more urgent in respect of legal research than in respect of research by social scientists.").

124. See Lee McConnell \& Rhona Smith, "Mixing Methods": Reflections on Compatibility, in RESEARCH METHODS IN HUMAN RIGHTS, supra note 29, at 150, 163 ("Researchers should be aware that different methods can result in different approaches to a problem."); see also Andreassen et al., supra note 31, at 4 ("In making methodological choices, the researcher . . usually acknowledges and explores underlying premises, value commitments and theories."); Suzanne Egan, The Doctrinal Approach in International Human Rights Law Scholarship, in RESEARCH METHODS IN HUMAN RIGHTS, supra note 29, at 24, 36 ("The critique .. . to the effect that doctrinal scholars sometimes fail to acknowledge the theoretical, ideological or value-perspective on which their analysis is based applies . . . to doctrinal scholarship in the field of international human rights."); Anne Peters, Realizing Utopia as a Scholarly Endeavour, 24 EUR. J. INT'L L. 533, 542 (2013) ("A complete value-free academic activity appears impossible, because any kind of statement and any interpretation are pre-structured by the speaker's Vorverständnis [preconceptions]. . . . [A]ll academic activity is inescapably political."). 
and (3) contextual analyses. The discussion of these choices illustrates the importance of methodological rigor in scholarship on intellectual property and human rights. That discussion will showcase the existence of a wide variety of research methods beyond doctrinal interpretation - the favorite method used by legal scholars and those human rights scholars who focus primarily on statutory rights and international treaty obligations. ${ }^{125}$ This part underscores the frequent need to use more than one method to conduct research in the area of intellectual property and human rights.

\section{A. Comparative Methods}

With the growing discussion of human rights protection in the global context and in relation to international and regional human rights instruments, the wide use of comparative methods is unsurprising. ${ }^{126}$ These methods "provide ways ... to compare similarities and differences across countries to arrive at a series of generalizations about particular human rights problems." 127 Comparative research will not only provide useful insights into the protection of human rights across the world, ${ }^{128}$ but will also help

125. As Suzanne Egan observed:

[T] he doctrinal method is one of the oldest research methodologies known to legal scholarship and one that is very much associated with the practising legal profession. ... [This] method is ... a valuable research technique in elucidating and critiquing the content and normative reach of law. When skilfully executed, its value lies in illuminating and critiquing legal reasoning, highlighting trends and predicting the implications of particular case law. Increasingly, doctrinal research acts as a complement to empirical research by explaining the normative assumptions on which an empirical project is based. This is particularly true in the case of international human rights scholarship in which doctrinal scholarship and social science methods very often go hand in hand in explaining the substance of human rights and the extent to which such rights are being adequately protected.

Egan, supra note 124, at 41; see also LANDMAN, supra note 26, at 1 ("The field of human rights has long been dominated by the discipline of law, which has been dedicated to studying (and in part advancing) the normative evolution in the promotion and protection of human rights." (citation omitted)).

126. See Bård A. Andreassen, Comparative Analyses of Human Rights Performance, in RESEARCH METHODS HANDBOOK, supra note 29, at 222, 222 ("Human rights protection and monitoring inevitably entail comparison. When international human rights bodies discuss human rights performance in single countries or across countries, they apply comparative approaches to receive reliable understandings of the state of affairs.").

127. Todd Landman, Social Science Methods and Human Rights, in METHODS OF HUMAN RIGHTS RESEARCH, supra note 29, at 19, 31.

128. See Sue Farran, Comparative Approaches to Human Rights, in RESEARCH METHODS 
deepen our understanding of the limitations of human rights protection in the intellectual property area. Thus far, researchers have identified different approaches to conduct comparative studies. These approaches depend on how much the researchers want to zoom in on the human rights developments in question. ${ }^{129}$

Research of the broadest scale involves global comparisons, which "tend to make broad ranging empirical generalizations using concepts and constructs at a fairly high level of abstraction." 130 These comparisons "typically involve] the use of large and complex data sets comprised of variables that have been operationalised quantitatively ... and have been specified in such a way that they can be measured over time and across space." 131 According to Todd Landman, a leading expert on human rights measurements, "[ $t]$ he main strengths of this kind of analysis include statistical control to rule out rival explanations, extensive coverage of cases, the ability to make strong inferences, and the identification of 'deviant' cases or 'outliers'." 132

By contrast, research of the smallest scale involves a single country. This type of single-case analysis "tends to limit . . . its empirical generalizations and concentrates on the contextual particularities of the single case under investigation, but can be constructed in such a way to contribute to larger theoretical and empirical

IN HUMAN RIGHTS, supra note 29, at 134, 137 [hereinafter Farran, Comparative Approaches] ("Comparative insights might ... provide a deeper and broader appreciation of how the law works in different contexts. This is particularly relevant to human rights, because the context requires us to take into account political, cultural and socio-economic factors."); Rhona Smith \& Lee McConnell, Introduction to Human Rights Research Methods, in RESEARCH METHODS IN HUMAN RIGHTS, supra note 29, at 1, 5 ("Comparative approaches can be used to contextualise knowledge and understanding. They can offer cross-cultural or transcontinental understandings.").

129. See LANDMAN, supra note 26, at 64-65 ("There are three general comparative methods available to social scientists of human rights: global comparisons, few-country comparisons, and single-case studies. The trade-offs associated with these methods involve the degree to which each can make broad-ranging empirical generalizations at different levels of theoretical and conceptual abstraction.").

130. Landman, supra note 127 , at 31 ; see also Andreassen, supra note 126, at 226 ("[L]arge- $n$ comparison (sometimes referred to as global comparison or statistical comparison) aims at statistical analysis and explanatory generalizations . . . .").

131. Landman, supra note 127 , at 31 .

132. Id.; see also Andreassen, supra note 126, at 240-41 ("A main strength of global or statistical comparison is that by statistical control we may rule out alternative explanations, give evidence for strong inferences and theory-building, and identify 'deviant' cases or 'outliers', that is, surprising or unexpected values on the dependent variable of the unit (country) given the value of the independent variable."). 
problems."133 Classic examples of single-case analysis "include official reports from international governmental and non-governmental organizations, domestic commissions and [non-governmental organizations], journalistic and descriptive accounts, and research monographs."134 Frequently, researchers use single-case analyses to explore the human rights practices in "problematic" countries. ${ }^{135}$ Cases in point are those conducted on the limited Internet freedoms enjoyed by netizens in China, Russia, and the Middle East. ${ }^{136}$

Single-case analyses have several strengths. As Professor Landman noted, these analyses "provide important contextual description upon which other studies build their analyses." 137 They may also feature comparisons over time using time series data. ${ }^{138}$ In addition, single-case analyses, such as single-country studies, provide three additional benefits:

Beyond their pure descriptive function, single-country studies can make significant and valuable contributions to the study of human rights... [by] establishing new classifications.... [These] studies are also useful for generating hypotheses for theories that have yet to be specified fully. As "plausibility probes", single-country studies explicitly (or implicitly) suggest that the generated hypothesis ought to be tested in a larger selection of countries. ... Finally, single-country studies are useful if they act as "crucial" cases drawn from theoretical

133. Landman, supra note 127, at 31; see also Andreassen, supra note 126, at 226 ("Single case study design . . . aims at in-depth analysis of individual cases.").

134. Landman, supra note 127, at 36; see also International Covenant on Civil and Political Rights art. 40(1), Dec. 16, 1966, 999 U.N.T.S. 171 (1976) (requiring parties to the covenant to "submit reports on the measures they have adopted which give effect to the rights recognized herein and on the progress made in the enjoyment of those rights"); ICESCR, supra note 9, arts. 16-17 (requiring contract parties to submit reports on measures relating to the rights protected under the ICESCR); Judith Eleanor Innes, Human Rights Reporting as a Policy Tool: An Examination of the State Department Country Reports, in HUMAN RIGHTS AND STATISTICS, supra note 29, at 235 (analyzing the U.S. State Department's Country Reports on Human Rights Practice).

135. See Landman, supra note 127 , at 36 (noting that single-country studies have "focus[ed] on countries with particularly problematic human rights records").

136. See generally ACCESs Denied: THE PRACTICE AND POLICY OF GLOBAL INTERNET FLLTERING (Ronald Deibert et al. eds., 2008) (documenting the information-control policies in these countries and other parts of the world).

137. Landman, supra note 127 , at 68.

138. See Andreassen, supra note 126, at 222 (noting that the gap between rights in principle and rights in practice "can be compared ... within a country over time by use of time series data"). 
expectations and propositions about the world. Such crucial case studies can confirm or infirm existing theories and are therefore conducted within the confines of extant generalizations. ${ }^{139}$

Somewhere between global comparisons and single-case analyses are those studies covering a select group of countries, usually based on similar characteristics, geographical proximity, or organizational memberships. These focused comparisons "tend to limit their generalizations and lower the level [of] abstraction in analysing human rights problems across a selection of countries." ${ }^{140} \mathrm{Be}-$ cause researchers carefully choose the countries they study, ${ }^{141}$ the resulting analyses feature "more of the nuances specific to [the cases concerned]" even though they are more intensive than global comparisons. ${ }^{142}$ Classic examples are regional and area studies, which "compare] countries that share similar history, language, religion, politics, and culture and then isolate[ the remaining factors that vary across the cases to see if that variation is related to

139. Landman, supra note 127 , at 36-37 (footnote omitted).

140. Id. at 31 .

141. These countries are generally selected based on two methods: most similar system design ("MSSD") and most different system design ("MDSD"). MSSD "compares countries that are similar on as many features as possible assuming that this provides the optimal sample for comparison. . . MDSD selects countries that share few common features apart from the political outcome to be explained, or one or two explanatory factors (independent variables) likely to explain the outcome." Andreassen, supra note 126, at 244-45. As Professor Landman explained:

Both MSSD and MDSD seek to identify a relationship between explanatory factors and outcomes by comparing different outcomes across similar countries or similar outcomes across different countries. Of the two research designs, MSSD is slightly more robust, since it allows for the presence of different outcomes across the countries under investigation, such that the dependent variable is actually allowed to vary. In contrast, MDSD does not allow for the presence of different outcomes, and thus has no variance in the dependent variable (a form of selection bias). MDSD thus establishes a concomitance of explanatory factors and outcomes since it does not allow for "negative" instances of the outcomes being examined. Moreover, the number of outcomes that have actually occurred in the world limits the number of countries this framework of analysis can include in any one comparison (i.e. there are a finite number of outcomes of interest).

Landman, supra note 127, at 34 (footnote omitted).

142. Landman, supra note 127, at 33; see also Andreassen, supra note 126, at 244 ("While few-cases comparison can draw on statistical evidence, it is generally more intensive and contextual than large- $n$ comparison. It gives more space to the description and analysis of each case, and may also typically take a historical (longitudinal or short) perspective. A focus on differences and similarities of cases rather than differences in the relationship between variables, makes it 'case oriented' as opposed to the 'variable orientation' of large- $n$ comparison."). 
the variation in the outcome that is to be explained." ${ }^{143}$ As widely used as they are, studies that rely on few- $n$ comparisons suffer from two methodological weaknesses:

First, such studies may identify a large number of explanatory variables whose full variation far exceeds the number of countries under investigation. This problem is commonly labelled "too many variables, not enough countries", or "too many inferences and not enough observations"....

Second, the intentional selection of cases rather than a random selection can seriously undermine the types of inferences that can be drawn. This problem is known as selection bias, and occurs in comparative politics through the non-random choice of countries for comparison, or the deliberative selection by the comparativist. ${ }^{144}$

Thus far, this subpart has focused only on the size of the comparative sample. Once researchers have figured out whether to undertake a large- $n$, few- $n$, or single-case study, they will have to further determine what to compare (tertium comparationis) ${ }^{145}$ and what comparison will be meaningful in the intellectual property context. To achieve the latter, the researcher will need to select the best option to assess the differing levels of intellectual property protection and enforcement-issues that will be discussed in the next subpart on quantitative assessments. ${ }^{146}$

Complications could arise considering the significantly different developments in countries with well-established intellectual property systems and those having nascent but rapidly improving systems. For the latter group of countries, it will be quite important to study not only the human rights developments at the time of the research project, but also changes in these developments, as well as the potential trends that would, or could, affect future developments. ${ }^{147}$ These changes and trends are particularly important in

143. Landman, supra note 127 , at $33-34$.

144. Id. at 34-35 (footnote omitted).

145. See Peter K. Yu, Enforcement, Economics and Estimates, 2 WIPO J. 1, 13-17 (2010) [hereinafter Yu, Enforcement, Economics and Estimates] (discussing the challenges of locating the tertium comparationis in comparative analysis).

146. See infra text accompanying notes 172-78 (discussing the various data sources or indicators that have been used to measure intellectual property protection and enforcement).

147. See LANDMAN \& CARVALHO, supra note 29, at 40 (noting the use of indices to "track both the level of development and the change in development, both of which are... linked to the notion of fulfilling social and economic rights"). 
countries that are experiencing rapid development of their intellectual property systems. In China, for instance, analyzing the relationship between intellectual property and human rights today is likely to differ significantly from such an analysis a decade ago. ${ }^{148}$

\section{B. Quantitative Assessments}

In the past decade, legal scholarship has taken an empirical turn. ${ }^{149}$ Like legal scholarship, human rights scholarship has also increasingly emphasized empirical analysis - in particular, analysis in quantitative terms. ${ }^{150}$ Quantitative assessments focus on "the distributions [the collected] data exhibit and the relationships that can be established between numeric variables using simple and advanced statistical methods." 151 These assessments are "particularly useful for identifying trends and patterns which are statistically significant. ... [They] can also be used to objectively analyse phenomenon." 152

To a large extent, the growing emphasis on quantitative analysis has been the result of the growing demand for human rights impact assessments. ${ }^{153}$ Such assessments have become increasingly

148. See Peter K. Yu, A Half-Century of Scholarship on the Chinese Intellectual Property System, 67 AM. U. L. REV. 1045, 1079-87 (2018) (discussing the development of the Chinese intellectual property system at its indigenization and transformation phase); Peter K. Yu, The Rise and Decline of the Intellectual Property Powers, 34 CAMPBELL L. REV. 525, 529-32 (2012) (noting that China is at the cusp of crossing over from a pirate nation to a country respectful of intellectual property rights); Peter K. Yu, When the Chinese Intellectual Property System Hits 35, 8 QUEEN MARY J. INTELL. PROP. 3 (2018) (discussing the transformation of the Chinese intellectual property regime in the past thirty-five years).

149. See generally THE OXFORD HANDBOOK OF EMPIRICAL LEGAL RESEARCH (Peter Cane \& Herbert M. Kritzer eds., 2010) (providing an excellent collection of articles discussing empirical legal research); Gregory Shaffer \& Tom Ginsburg, The Empirical Turn in International Legal Scholarship, 106 AM. J. INT'L L. 1 (2012) (discussing the empirical turn in international legal scholarship).

150. See Paul Gready, Telling Truth?: The Methodological Challenges of Truth Commissions, in METHODS OF HUMAN RIGHTS RESEARCH, supra note 29, at 159, 159 ("Research methods are a relatively recent concern of both human rights organizations and academics studying human rights."); Smith \& McConnell, supra note 128, at 4-5 ("Increasingly, human rights are defined in terms of indicators - the millennium development goals are a prime example-and thus quantitative methods are required to populate progress charts and demonstrate compliance with standards.").

151. Landman, supra note 127 , at 39.

152. Smith \& McConnell, supra note 128, at 4 .

153. See Audrey R. Chapman, Development of Indicators for Economic, Social and Cul- 
common in not only the human rights field, but also in the areas of public health and biological diversity. ${ }^{154}$ Assessment, evaluation, and impact studies also constitute one of the six clusters of recommendations adopted as part of the WIPO Development Agenda in October 2007.155

tural Rights: The Rights to Education, Participation in Cultural Life and Access to the Benefits of Science, in HUMAN RIGHTS IN EDUCATION, supra note 15, at 111, 111 [hereinafter Chapman, Development of Indicators] ("Effective monitoring requires the systematic collection and analysis of appropriate data."); LANDMAN \& CARVALHO, supra note 29, at 2 ("The measurement and monitoring of human rights has been a mainstay activity of human rights non-governmental organizations ... primarily for advocacy purposes and since the $1980 \mathrm{~s}$ has become increasingly important for a wide range of human rights scholars and practitioners working across the broad spectrum of human rights issue areas from many different disciplinary perspectives."); Simon Walker, Challenges of Human Rights Measurement, in RESEARCH METHODS HANDBOOK, supra note 29, at 306, 307 ("The need for more accurate measurement has intensified recently with the expansion of human rights monitoring through commissions of inquiry, truth commissions and protection work in conflict and postconflict zones, as well as prosecutions before international courts. Governments, business enterprises and civil society organizations are increasingly undertaking human rights impact assessments of laws, policies and practices ....").

154. See, e.g., Convention on Biological Diversity art. 14(1)(a), June 5, 1992, 1760 U.N.T.S. 143 (requiring contracting parties to "[i]ntroduce appropriate procedures requiring environmental impact assessment of its proposed projects that are likely to have significant adverse effects on biological diversity with a view to avoiding or minimizing such effects and, where appropriate, allow for public participation in such procedures"); General Comment No. 17, supra note 8, ๆ 35 ("States parties should ... consider undertaking human rights impact assessments prior to the adoption and after a period of implementation of legislation for the protection of the moral and material interests resulting from one's scientific, literary or artistic productions."); Special Rapporteur's Report on Copyright Policy, supra note 17, I 94, 96 ("International copyright instruments should be subject to human rights impact assessments and contain safeguards for freedom of expression, the right to science and culture, and other human rights.... States should complete a human rights impact assessment of their domestic copyright law and policy, utilizing the right to science and culture as a guiding principle."); Special Rapporteur's Report on Patent Policy, supra note 17, ๆ9 95, 97 ("International patent instruments should be subject to human rights impact assessments and contain safeguards for human rights, including the right to health, food, science and culture. ... States should complete a human rights impact assessment of their domestic patent law and policy."); COMM'N ON INTELleCtuAl ProP. RIGHTS, innovation \& Pub. Health, World Health ORg., Public Health, Innovation and INTELLECTUAL PROPERTY RIGHTS 10 (2006) (stating that "[h]ealth policies, as well as inter alia those addressing trade, the environment and commerce, should be equally subject to assessments as to their impact on the right to health"); HARRISON, supra note 26, at 228 ("Systematic environmental assessments of trade agreements are relatively common. Norway, the US and Canada all carry out reviews of the environmental impact of trade policies which include some international impact assessment, as do the United Nations Environment Programme and World Wildlife Fund.").

155. See The 45 Adopted Recommendations Under the WIPO Development Agenda, WIPO, http://www.wipo.int/export/sites/www/ip-development/en/agenda/recommendations. pdf [https://perma.cc/M654-7K7V] (last visited Apr. 1, 2019). 
Although it is generally a good idea to conduct empirical analysis, undertaking quantitative assessments on human rights protection is not always easy. The protection of some human rights, such as the freedom of opinion and expression, is particularly hard to quantify. Although freedom indicators or indices do exist and provide useful summative assessments, commentators have questioned their validity and reliability. ${ }^{156}$

In the area of economic, social, and cultural rights, to which the right to the protection of the moral and material interests resulting from intellectual production belong, researchers have amassed a wide variety of data for quantitative assessment purposes. ${ }^{157}$ To evaluate the protection and fulfillment of the right to health, for example, researchers can analyze "death rates (mortality), illness (morbidity), health behaviors, or health knowledge."158 They could also examine the right with respect to its essential elements (such as availability, accessibility, acceptability, and quality ${ }^{159}$ ) or its

156. See LANDMAN, supra note 26 , at 65 (noting that "serious questions remain[ about the validity and reliability" of some of the widely used human rights measures). One of the most widely used freedom indicators are those Freedom House has provided since 1973. See FREEDOM House, FREEDOM IN THE WORLD 2018 (2018), https://freedomhouse.org/sites/def ault/files/FH_FITW_Report_2018_Final_SinglePage.pdf [https://perma.cc/RX9C-CWVL] (providing the latest report that evaluates the state of freedom in 195 countries and 14 territories in 2017); Raymond Duncan Gastil, The Comparative Survey of Freedom: Experiences and Suggestions, 25 STUD. COMP. INT'L DEV. 25 (1990) (discussing the early methodology advanced for the Comparative Survey of Freedom, produced by Freedom House from 1975 to 1989); see also LANDMAN \& CARVALHO, supra note 29, at 37-38 (providing other examples of standards-based measures, such as "the 'political terror scale', a scale of torture, and a series of seventeen different rights measures collected by Cingranelli and Richards" (citations omitted)). Nevertheless, researchers have noted problems with these indicators. See LANDMAN \& CARVALHO, supra note 29, at 68-73 (discussing the Freedom House checklist for political rights and civil liberties); George A. Lopez \& Michael Stohl, Problems of Concept and Measurement in the Study of Human Rights, in HUMAN RIGHTS AND STATISTICS, supra note 29, at 216, 223 (discussing the shortcomings of the indicators provided by Freedom House); see also Malcolm Langford, Interdisciplinarity and Multimethod Research, in RESEARCH METHODS HANDBOOK, supra note 29, at 161, 179-80 (noting the problems posed by human rights indicators).

157. But cf. Siobhán McInerney-Lankford, Legal Methodologies and Human Rights Research: Challenges and Opportunities, in RESEARCH METHODS HANDBOOK, supra note 29, at 38, 52 ("[Q]uantitative methods may be more difficult to use for economic and social rights than for civil and political rights.").

158. HELFER \& AUSTIN, supra note 19, at 321; see also Dabney Evans \& Megan Price, Measure for Measure: Utilizing Legal Norms and Health Data in Measuring the Right to Health, in METHODS OF HUMAN RIGHTS RESEARCH, supra note 29, at 111 (advancing an approach that combines human rights discourse with traditional public health data analyses).

159. See Comm. on Econ., Soc. \& Cultural Rights, General Comment No. 14: The Right to the Highest Attainable Standard of Health (Art. 12), 17 12, U.N. Doc. E/C.12/2000/4 (Aug. 
three distinct obligations (to respect, to promote, and to fulfill). ${ }^{160}$ Likewise, regarding the right to education, researchers can examine basic literacy and numeracy rates; costs, quality, and level of education; and percentage of government spending on different forms of education. ${ }^{161}$

To foster research in this area, the OHCHR put together a list of indicators regarding the rights to life, food, health, and education and the freedom of opinion and expression, among others. ${ }^{162}$ These indicators have been further divided based on their different attributes and a three-level standard typology (structural, process, and outcome). ${ }^{163}$ Although this typology effectively separates the different types of indicators, some commentators worry that the typology may undermine the respect-protect-fulfill framework used widely in the international human rights system. ${ }^{164}$

Notwithstanding these helpful assessment tools, some rights, especially those in the areas of economic, social, and cultural rights, have remained highly difficult to measure, due in large part to their limited normative development. As Audrey Chapman reminded us: "The determination of which data are relevant [for empirical analysis] requires translating the abstract legal norms in which various human rights covenants are framed into operational

11,2000 ) (including availability, accessibility, acceptability, and quality among the "interrelated and essential elements, the precise application of which will depend on the conditions prevailing in a particular State party").

160. See LANDMAN \& CARVALHO, supra note 29, at 128 ("[T] he measurement effort has much work to do in finding solutions for measuring these three different state obligations.").

161. See Chapman, Development of Indicators, supra note 153, at 125; HELFER \& AUSTIN, supra note 19 , at $321-22$.

162. See OHCHR, HUMAN RIGHTS INDICATORS: A GUDE TO MEASUREMENT AND IMPLEMENTATION 89 (2012), https://www.ohchr.org/Documents/Publications/Human_rights _indicators_en.pdf [https://perma.cc/825W-BLFY] (providing "[i]llustrative indicators on the right to adequate food"); $i d$. at 90 (providing "[i]llustrative indicators on the right to the enjoyment of the highest attainable standard of physical and mental health"); id. at 93 (providing "[i]llustrative indicators on the right to education"); id. at 97 (providing illustrative indicators on "[t]he right to freedom of opinion and expression"); $i d$. at 101 (providing "[i]llustrative indicators on the right to life").

163. See Walker, supra note 153, at 325-27 (discussing the OHCHR indicator framework).

164. See Sally Engle Merry, The Potential of Ethnographic Methods for Human Rights Research, in RESEARCH METHODS HANDBOOK, supra note 29, at 141, 144 (criticizing this typology for being less flexible than the respect-protect-fulfill framework used widely in the international human rights system). 
standards. This process involves conceptualizing specific enumerated rights . . . and developing standards by which to measure implementation or identify violations of state obligations."165

A case in point is the challenge of measuring cultural rights, which are particularly hard to define. Indeed, "[i]ssues of culture, cultural values and cultural rights are often complex and frequently touch on politically sensitive and contested issues." 166 It is no wonder that Raymond Williams declared that "culture is one of the two or three most complicated words in the English language." 167

As far as the relationship between intellectual property and human rights is concerned, researchers can take quantitative assessments in two different directions. The first type of assessment concerns the human rights impact of intellectual property law and policy. Drawing on comparative methods discussed in the previous subpart, researchers can easily conduct cross-country comparisons

165. Chapman, Development of Indicators, supra note 153, at 111; see also Robert Justin Goldstein, The Limitations of Using Quantitative Data in Studying Human Rights Abuses, in HUMAN RIGHTS AND STATISTICS, supra note 29, at 35, 38 ("Quantitative data collection requires a clear definition of the subject under study, but defining what are human rights poses enormous difficulties."). As Todd Landman observed:

A social science that seeks to make human rights its main object of inquiry must confront three significant and complementary challenges: (1) the absence of agreed philosophical foundations for the existence of human rights and their uncertain character, (2) contestation over the meaning and core content of human rights, and (3) the applicability of the social sciences to the study of human rights.

Landman, supra note 127 , at 21.

166. Chapman, Development of Indicators, supra note 153, at 132; see also Yvonne Donders, The Legal Framework of the Right to Take Part in Cultural Life, in HUMAN RIGHTS IN EDUCATION, supra note 15, at 231, 232 ("The main reason for the underdevelopment of cultural rights is that the term 'culture' remains broad and vague, which has led to a lack of consensus on which rights are 'cultural' and how to best implement them."); Lyndel V. Prott, Cultural Rights as Peoples' Rights in International Law, in THE RIGHTS OF PEOPLES 93, 95 (James Crawford ed., 1988) ("Th[e] different shades of meaning are often ignored in discussions of cultural rights, but their existence shows that any attempt to talk about cultural issues in terms of rights may be slippery and difficult. Culture is not a static concept: cultures change all the time, and even the most enthusiastic supporter of cultural preservation would no doubt find elements in the culture under consideration which no special effort should be made to preserve."); Frans Viljoen, The Justiciability of Socio-Economic and Cultural Rights: Experience and Problems, in HUMAN RIGHTS IN EDUCATION, supra note 15, at 53,54 ("Delineating cultural rights is complex, in part because of the different understandings one may have of 'culture.".).

167. RAYMOND WILLIAMS, KEYWORDS: A VOCABULARY OF CULTURE AND SOCIETY 87 (Oxford Univ. Press rev. ed. 1985). 
of the human rights impacts of intellectual property laws and policies in multiple countries. ${ }^{168}$ In doing so, they can demonstrate whether stronger protection and enforcement of intellectual property rights has led to increases or decreases in human rights protections in the intellectual property area. Because changes in intellectual property law and policy rarely result in identifiable "victims," 169 researchers will also need to think more about how to measure the impact of these changes on human rights protection.

Before this line of research is undertaken, however, researchers will have to determine not only which data or indicators best reflect the levels of human rights protection, ${ }^{170}$ but also what data sources or indicators can reveal the actual levels of intellectual property protection and enforcement. ${ }^{171}$ Commentators have widely used the Ginarte-Park index to document the strength of an intellectual property system. ${ }^{172}$ Other indices that scholars and institutions

168. See LANDMAN, supra note 26 , at 3 ("[C]ross-cultural generalizations are an essential and inherent feature of human rights research since the international law of human rights sets a universal ideal standard against which country performances and cultural contexts are compared, and it is entirely possible to make cross-cultural generalizations if certain basic rules of social science inquiry are observed." (citation omitted)).

169. Angelina Godoy observed the challenge of measuring the human rights impact of intellectual property law and policy:

[M] easuring intellectual property's impact is not as straightforward as it might seem. Because IP rules delay the entrance of generic versions of new drugs, their impact is only gradually felt as new drugs become available without generic alternatives. But no one is wresting pills out of poor patients' clenched fists; dispassionate bureaucratic decisions mean prices will stay higher, longer, but most patients will be given an older drug or prescribed an alternate therapy, rather than denied treatment altogether. There are likely to be patients who receive a less than ideal therapy and programs for which there are fewer funds because more is spent on medicines, but most likely there will never be a quantifiable "body count."

GODOY, supra note 21, at 46; see also HARRISON, supra note 26, at 235 (calling for the development of "human rights indicators ... with specific relevance to trade agreements and their impacts").

170. See Yu, Nonmultilateral Era, supra note 23, at 1097 n.237 (listing as helpful resources the U.N. indicators compiled by the United Nations Statistical Division, the International Human Development Indicators compiled by the United Nations Development Programme, and the World Development Indicators compiled by the World Bank). See generally OHCHR, supra note 162 (providing a detailed guide on the development and use of human rights indicators).

171. See Andreassen, supra note 126 , at 242-43 ("To choose indicators that are apt proxies to the phenomenon a researcher wants to measure (do they measure what was expected) is critical, but often problematic.").

172. See Juan C. Ginarte \& Walter G. Park, Determinants of Patent Rights: A CrossNational Study, 26 RES. POL'Y 283 (1997) (providing an index of patent rights for 110 countries from the period 1960-1990). As they explained: 
have advanced are the U.S. Chamber International IP Index developed by the Chamber's Global Innovation Policy Center, ${ }^{173}$ the Global Intellectual Property Index provided by the international law firm of Taylor Wessing, ${ }^{174}$ and, most recently, the Intellectual Property (Patent) Flexibility Index created by the late Elizabeth Siew-Kuan Ng. ${ }^{175}$

The index was constructed for each of the 110 countries in the sample, quinquennially from 1960 to 1990 , using a coding scheme applied to national patent laws. Five categories of the patent laws were examined: (1) extent of coverage, (2) membership in international patent agreements, (3) provisions for loss of protection, (4) enforcement mechanisms, and (5) duration of protection. Each of these categories (per country, per time period) was scored a value ranging from 0 to 1 .... The unweighted sum of these five values constitutes the overall value of the patent rights index. The index, therefore, ranges in value from zero to five. Higher values of the index indicate stronger levels of protection.

Id. at 284 (footnote omitted); see also Walter G. Park \& Juan Carlos Ginarte, Intellectual Property Rights and Economic Growth, 15 CONTEMP. ECON. POL'Y 51, 51 (1997) (providing an earlier study that covered only sixty countries from the same period).

173. See U.S. Chamber of Commerce Glob. InNovation POLICY CTR., U.S. Chamber INTERNATIONAL IP INDEX (2018), https://www.theglobalipcenter.com/wp-content/uploads/ 2018/02/GLPC_IP_Index_2018.pdf [https://perma.cc/N9FR-8BGZ]. As the Center's latest report stated:

The Index consists of 40 indicators across 8 separate categories:

i) Patents, Related Rights, and Limitations;

ii) Copyrights, Related Rights, and Limitations;

iii) Trademarks, Related Rights, and Limitations;

iv) Trade Secrets and Related Rights;

v) Commercialization of IP Assets;

vi) Enforcement;

vii) Systemic Efficiency; and

viii) Membership in and Ratification of International Treaties.

Id. at 163 .

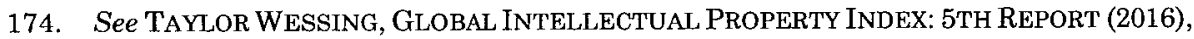
https://united-kingdom.taylorwessing.com/documents/get/576/gipi5-report.pdf/show_on_sc reen [https://perma.cc/5XDP-2BWZ]. As the firm's report explained:

The Global Intellectual Property Index (GIPI) provides a comprehensive assessment of how the intellectual property ... regimes of 43 important jurisdictions compare with each other. The European Union is treated as an additional jurisdiction in relation to $\mathrm{IP}$ rights that have been harmonised, i.e., trade marks and designs.

Each IP right (patents, trade marks, designs and copyright) is assessed as regards obtaining, exploiting, enforcing and attacking it. Each data protection regime is measured against the criteria of fairness, enforcement, compliance, administrative burden and disruption ....

Id. at 2 .

175. This index "rank[s] thirty Asian countries according to the degree to which they have implemented TRIPS patent flexibilities using five main indicators: namely, compulsory licensing, parallel importation, experimental/private noncommercial use, regulatory review exception, and TRIPS-specific exclusions." Elizabeth Siew-Kuan Ng \& Albert Guang- 
Since the mid-1990s, researchers have also put together rankings based on subjective assessments made by industry representatives, intellectual property managers, academic researchers, and all or some of the above. For instance, Edwin Mansfield conducted for the World Bank a highly influential survey of 100 major U.S. firms in six industries to explore the relationship between the respect for intellectual property rights and the flow of foreign direct investments. ${ }^{176}$ Robert Sherwood also provided the ratings of eighteen developing countries based on the effectiveness of their intellectual property regime. ${ }^{177}$ In addition, WIPO released annual data concerning different forms of intellectual property rights, including patents, utility models, trademarks, industrial designs, plant varieties, and geographical indications. ${ }^{178} \mathrm{All}$ of these studies have their strengths and shortcomings.

The second type of assessment concerns the protection of the human rights aspects of the right to the protection of the moral and material interests resulting from intellectual production. Although it is tempting to use the level of intellectual property protection and enforcement as a proxy for such protection, researchers can

zhou $\mathrm{Hu}$, Flexibilities in the Implementation of TRIPS: An Analysis of Their Impact on Technological Innovation and Public Health in Asia, in FRAMING INTELLECTUAL PROPERTY LAW IN THE 21St Century: INTEGrating Incentives, Trade, Development, Culture, AND Human RIGHTS 115, 118 (Rochelle Cooper Dreyfuss \& Elizabeth Siew-Kuan Ng eds., 2018).

176. Edwin Mansfield, Intellectual Property Protection, Foreign Direct Investment and Technology Transfer (Int'l Finance Corp., Discussion Paper No. 19, 1994). These six industries included "chemicals (including drugs), transportation equipment, electrical equipment, machinery, food and metals." Id. at 1.

177. Robert M. Sherwood, Intellectual Property Systems and Investment Stimulation: The Rating of Systems in Eighteen Developing Countries, 37 IDEA J.L. \& TECH. 261 (1997). As Sherwood explained:

This study presents a numerical rating system by which national intellectual property regimes may be both assessed and compared. The rating system examines regime effectiveness from the perspective of private investment stimulation, particularly national private investment. This system, in turn, may provide a basis for assessing the contribution which intellectual property protection makes to the process of economic development.

Id. at 261. Among the metrics used were enforceability, administration, substantive law (copyright, patents, trademarks, trade secrets, and life forms), treaties, and public commitment. Id. at 265. Similar estimates have been undertaken by other researchers. See, e.g., Belay Seyoum, The Impact of Intellectual Property Rights on Foreign Direct Investment, COLUM. J. WORLD BuS., Spring 1996, at 51, 56 (estimating the level of protection for patents, trademarks, trade secrets, copyrights in twenty-eight countries).

178. See WIPO, WORLd InTELlectual PROPERTY INDICAToRs 2018 (2018), https:/www. wipo.int/edocs/pubdocs/en/wipo_pub_941_2018.pdf [https://perma.cc/4E5T-JT5L] (providing these data). 
consider devoting greater attention to changes in the income of authors and inventors. ${ }^{179}$ As General Comment No. 17 stated, the right to the protection of the moral and material interests resulting from intellectual production seeks to protect the "material interests which are necessary to enable authors to enjoy an adequate standard of living." 180 A close scrutiny of their income will certainly shed light on whether individual authors and inventors have received adequate protection for this specific right.

To be sure, quantitative assessment alone may not reveal the complete picture, whether in terms of the human rights impacts of intellectual property rights or the protection for the human rights aspects of intellectual property rights. As Robert Goldstein observed, "[e]ven if human rights terms can be adequately defined and reliable quantitative information can be obtained, making intelligent assessments of such data will often be extraordinarily difficult, especially if the data are interpreted out of the context of other, nonquantitative sources, such as interviews, on-the-spot observation, and background reading." 181 As a result, researchers may want to supplement their quantitative assessments with qualitative analyses, ${ }^{182}$ such as those provided through structured,

179. For some of these studies, see Martin Kretschmer, Artists' Earnings and Copyright: A Review of British and German Music Industry Data in the Context of Digital Technologies, FIRST MONDAY, Jan. 2005, http://www.firstmonday.org/ojs/index.php/fm/ article/view/1200/ 1120 [https://perma.cc/78R6-YQYK]; Martin Kretschmer, Does Copyright Law Matter? An Empirical Analysis of Creators' Earnings (May 21, 2012), https://ssrn.com/abstract=20 63735 [https://perma.cc/J8Z6-9CH5]; Martin Kretschmer et al., Copyright Contracts and Earnings of Visual Creators: A Survey of 5,800 British Designers, Fine Artists, Illustrators and Photographers (Mar. 7, 2011), https://ssrn.com/abstract=1780206 [https://perma.cc/ VVS9-VTWK].

180. General Comment No. 17, supra note 8, If 2.

181. Goldstein, supra note 165 , at 49 .

182. See Laura Ferguson, Assessing Work at the Intersection of Health and Human Rights: Why, How and Who?, in RESEARCH METHODS HANDBOOK, supra note 29, at 408, 415 ("Assessing a country's compliance with its human rights commitments can be done based on both quantitative and qualitive evidence produced through studies and reports. Assessing how human rights impact health also requires a mix of quantitative and qualitative data."); LANDMAN, supra note 26, at 71-72 ("Quantitative methods seek to show differences in number between certain objects of analysis and qualitative methods seek to show differences in kind. . . . [T] in combining the strengths of qualitative and quantitative techniques by recognizing that both methods are founded on the same logic of inference and linking qualitative distinctions to quantitative representation."); Langford, supra note 156, at 176-80 (exploring the "quantitative us qualitative divide"); McConnell \& Smith, supra note 124, at 159 ("In human rights, [qualitative and quantitative methods] can be used independently, but often both are used, with qualitative methods being used to deepen understanding of the data reached after a quantitative analysis. Qualitative data can often 'soften' the perceived bluntness of 
semi-structured, and in-depth interviews. ${ }^{183}$ The two latter types of interviews will be particularly helpful in facilitating follow-up inquiries that seek to illuminate quantitative findings.

statistical data by providing further explanation for the statistics."); Shaffer \& Ginsburg, supra note 149 , at 4 ("Qualitative work ... offers the advantage of paying closer attention to dynamic social contexts, as it often involves field work and interviews."). But see Goldstein, supra note 165 , at 37 (cautioning against "overreliance on quantitative data and approaches").

183. Maria Stuttaford explained the distinctions between these various data collection techniques:

The first method of data collection to be employed in the research is a survey generating mainly quantitative data with a limited number of open ended questions. ... Semi-structured interviewing takes place when set questions are asked but not in any particular order. . . While semi-structured interviews focus on the individual, focus group interviews are particularly useful for eliciting views on a specific collective topic, such as rights to health. . . In-depth interviews are particularly useful for engaging with people with regard to meanings of phenomena. In the research on health and human rights, in-depth interviews as narrative may improve the focus and rigour of data, compared to the first two studies.

Maria Stuttaford, Methods in Health and Human Rights Research: Towards a Spiral of CoLearning, in METHODS OF HUMAN RIGHTS RESEARCH, supra note 29, at 135, 154; see also Dimitrina Petrova, Researching Discrimination, in RESEARCH METHODS HANDBOOK, supra note 29, at 379,389 ("There are various kinds of interview: structured (based on a rigorous questionnaire), semi-structured (following pre-ordered themes but allowing for deviation based on respondent's answers) and exploratory (investigating a certain issue and lacking a preliminary plan, guided by the need to establish facts, as when researching a specific incident)."); Smith \& McConnell, supra note 128, at 4 ("Often such data will be collected through interviews. These may be structured or semi-structured, depending on the research questions and the time available and scope of the research. Data can also be collected through face-to-face interviewing or through a more remote survey of some type."); Rhona Smith \& Lorna Smith, Qualitative Methods, in RESEARCH METHODS IN HUMAN RIGHTS, supra note 29, at 70,72-79 (discussing interviews, surveys, focus groups, and case studies).

Research in the area of intellectual property and human rights is generally not as sensitive as research conducted in other areas of human rights protection, such as those relating to genocide, torture, or abuse of women's rights. Nevertheless, issues involving suffering or deaths resulting from a lack of access to essential medicines or the systemic failure to protect traditional knowledge and cultural expressions can be highly sensitive and emotionally charged. See id. at 83 ("Human rights research often involves particularly vulnerable people."); George Ulrich, Research Ethics for Human Rights Researchers, in RESEARCH METHODS HANDBOOK, supra note 29, at 192, 192 ("Research in the area of human rights, like human rights practice, invariably concerns issues that in one way or another are sensitive and charged."). It is therefore no surprise that "[m]any international professional organizations (e.g., Bar Associations), civil society organisations and non-governmental organisations have their own guidelines for gathering information on human rights violations." Smith, supra note 103 , at 10 . See generally Ulrich, supra (discussing the ethics of conducting human rights research). 


\section{Contextual Analyses}

Commentators have increasingly embraced the "human rights in context" approach, which "advocates placing human rights and law in their natural setting, considering a range of factors including historical, cultural, religious and social-economic."184 The use of contextual analyses is understandable given the considerable variations of human rights protection from right to right, country to country, and discipline to discipline. While human rights discussions are frequently framed in terms of absolutes, reality does call for greater recognition of the varying levels of human rights protection. Even among developed countries, significant variations exist with respect to the protection of different human rights. ${ }^{185}$ As a result, "[s]tates and rights holders both need an understanding of law in context to maximise the opportunity for human rights to be meaningfully realised in the state." 186

To some extent, human rights are contextually contingent on the factors relating to the local protective environment. ${ }^{187}$ As a result of this contextual contingency, researchers can glean important insights from analyzing issues through different disciplinary lenses. ${ }^{188}$ For example, studying the right to the protection of the

184. Smith \& McConnell, supra note 128, at 3; see also Smith, supra note 103, at 12 ("A human rights based approach to research means researching human rights issues with due consideration as to the surrounding circumstances. This can mean ensuring an appropriate historical, cultural, religious, legal and political understanding of the issues which shape the subject.").

185. In the United States, the protection for civil and political rights tends to be stronger than the protection for social, economic, and cultural rights. See generally CASS R. Sunstein, The SECOND BRL of Rights: FDR'S UNFINISHED REVOLUTION AND WHY WE NEED IT MORE THAN EVER (2004) (discussing the protection of the latter set of rights and the lack thereof).

186. Smith \& McConnell, supra note 128 , at 3.

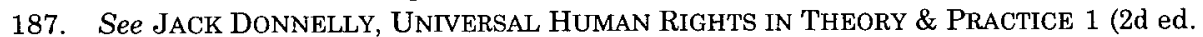
2003) ("A]ny list or conception of human rights-and the idea of human rights itself-is historically specific and contingent."); Ellen Dorsey, Charter Making and Participatory Research, in HUMAN RIGHTS EDUCATION, supra note 32, at 119, 124 (drawing on Richard Falk's research to point out that most other human rights "are necessarily contextually (that is not to say, hierarchically) contingent"); Farran, Comparative Approaches, supra note 128, at 141 (" $[\mathrm{T}]$ he economic and political environment in which the law operates is important and may be particularly relevant in the case of human rights, especially second generation rights.").

188. See Andreassen et al, supra note 31, at 5 ("Human rights are not only the subjects of legal obligations, they are also moral norms, with political content and social, cultural, anthropological and economic implications."); Langford, supra note 156, at 161-62 ("While temporal disciplinary monopolies and methodological paradigm wars have marked the field, 
moral and material interests resulting from intellectual production in its historical context ${ }^{189}$ will help researchers focus attention on the slow but active evolution of human rights protection in the past few decades. For a human rights instrument that was adopted seven decades ago, such as the UDHR, evolutive interpretation can be quite important. ${ }^{190}$ As Professors Helfer and Austin observed:

Human rights law and intellectual property law are both famously dynamic, readily adapting to changing circumstances through new rounds of treaty making, interpretations by international tribunals, and revisions of national laws. A framework that privileges the original understanding of Articles 27 and 15 fails to engage with this dynamism and with the evolutions in law, politics, social values, and technology that engendered these adaptations. ${ }^{191}$

Likewise, Maria Green observed in her widely cited study of the drafting history of Article 15(1)(c) of the ICESCR:

In the context of modern human rights issues, articles 15(1)(b) and 15(1)(c) of the ICESCR raise very real questions of interpretation and implementation. We face a world with issues that the drafters of the ICESCR could never have envisaged, from an AIDS epidemic reigning in one part of the world while the drugs that could help are largely owned in another, to scientifically engineered non-reproducing crops, to scientists "bio-prospecting" for traditional knowledge whose ownership does not fit into existing patent definitions. Then, too, with the recent tying of intellectual property to trade law, international intel-

human rights research has gradually embraced the pluralistic turn. ... [Human rights] is neither a discipline nor delimited by a single discipline; and it is both a research subject (internally determined) and research object (externally observed). This applies to academic scholarship but also to research in human rights practice."); Smith, supra note 103, at 22 ("Human rights is inevitably interdisciplinary and research on it can be interdisciplinary or even multidisciplinary.").

189. See Farran, Comparative Approaches, supra note 128, at 140 ("A . . . caveat when comparing legal systems or parts of legal systems is the need to be aware of the influence of the historical past."); Smith, supra note 103, at 12 ("Human rights research can benefit from historical approaches to research. Understanding why things are as they are, learning from past experiences of a situation, identifying trends and providing perspectives on current issues are examples of the richness historical approaches can bring to human rights research.").

190. See Audrey R. Chapman \& Sage Russell, Introduction to CoRE OBLiGations, supra note 36, at 1,13 (" $[\mathrm{H}]$ uman rights standards evolve over time and in the direction of expansiveness."); DONNELLY, supra note 187, at 1 (noting that human rights are far from "timeless, unchanging, or absolute; any list or conception of human rights-and the idea of human rights itself--is historically specific and contingent"); see also M. MAGDALENA SEPÚLVEDA, THE NATURE OF THE OBLIGATIONS UNDER THE INTERNATIONAL COVENANT ON ECONOMIC, SOCIAL AND CULTURAL RIGHTS 81-84 (2003) (discussing the evolutive interpretation of human rights treaties).

191. HELFER \& AUSTIN, supra note 19, at 507. 
lectual property rights have undergone a sea-change, becoming universal, compulsory, and enforceable in ways that were never dreamt of in the middle of the last century. ${ }^{192}$

A case in point concerns the protection for traditional knowledge and traditional cultural expressions. Commentators have widely noted that the drafters of the UDHR and the ICESCR did not pay much attention to issues relating to minorities. ${ }^{193}$ As a result, both instruments do not offer strong protection to traditional knowledge and traditional cultural expressions. As General Comment No. 17 noted, by using words such as "everyone," "he," and "author," "the drafters of [Article 15(1)(c) of the ICESCR] seemed to have believed authors of scientific, literary or artistic productions to be natural persons, without at that time realizing that they could also be groups of individuals." 194

In September 2007, however, the Declaration on the Rights of Indigenous Peoples was adopted, and the situation changed dramatically. Article 31 of this new instrument specifically provides: "Indigenous peoples have the right to maintain, control, protect and develop their cultural heritage, traditional knowledge and traditional cultural expressions .... They also have the right to maintain, control, protect and develop their intellectual property over such cultural heritage, traditional knowledge, and traditional cultural expressions." 195 This provision is consistent with paragraph 32 of General Comment No. 17, which declares: "States parties should adopt measures to ensure the effective protection of the interests of indigenous peoples relating to their productions, which are often expressions of their cultural heritage and traditional knowledge." 196

Apart from historical research, economic analyses can also help enhance our understanding of the interplay between intellectual

192. Maria Green (Director, Int'l Anti-Poverty Law Ctr.), Drafting History of the Article 15(1)(c) of the International Covenant on Economic, Social and Cultural Rights, If 44, U.N. Doc. E/C.12/2000/15 (Oct. 9, 2000).

193. See MORSINK, supra note 71, at 269-80 (showing why historical memories, political circumstances, concerms of the colonial powers, and the lack of political organization had caused the UDHR drafters to omit a provision on the right to protect minorities); Yu, Reconceptualizing Intellectual Property Interests, supra note 18, at 1144-45 (discussing how the drafters of both the UDHR and the ICESCR did not have indigenous communities in mind when they drafted the documents).

194. General Comment No. 17, supra note 8, 77 (footnote omitted).

195. UNDRIP, supra note 46 , art. 31(1).

196. General Comment No. 17, supra note 8, ๆ 32. 
property and human rights. Such analyses are especially significant in view of the different economies covered by the TRIPS Agreement and TRIPS-plus bilateral, regional, and plurilateral trade agreements. Variations in economic conditions affect not only human rights protection, but directly impact the levels of intellectual property protection and enforcement. These variations, in turn, affect the tensions and conflicts between human rights and intellectual property rights.

Consider, for instance, the protection of intellectual property rights in least developed countries. At its inception, the TRIPS Agreement granted to these countries a transition period of ten years, ${ }^{197}$ which was extended in November 2005 to seventeen and a half years. ${ }^{198}$ Thanks to a June 2013 decision of the Council for Trade-Related Aspects of Intellectual Property Rights, this transition period has been extended yet again for another eight years to July $1,2021 .{ }^{199}$ In the area of pharmaceuticals, least developed countries can further delay protection for patents and undisclosed test data until January 1, 2033. ${ }^{200}$ In short, the standards of intellectual property protection vary according to a country's economic strength, not to mention the additional impact of resource constraints on its overall ability to enforce intellectual property rights. ${ }^{201}$

Moreover, just as resource constraints can affect the level of intellectual property protection and enforcement, they can also impact the protection and full realization of the human rights concerned. Article 22 of the UDHR states that "the economic, social and cultural rights indispensable for [one's] dignity and the free

197. See TRIPS Agreement, supra note 39, art. 66.1 (providing the transition period for least developed countries).

198. Council for Trade-Related Aspects of Intellectual Property Rights, Extension of the Transition Period Under Article 66.1 for Least-Developed Country Members, WTO Doc. IP/C/40 (Nov. 30, 2005).

199. Council for Trade-Related Aspects of Intellectual Property Rights, Extension of the Transition Period Under Article 66.1 for Least Developed Country Members, WTO Doc. IP/C/64 (June 12, 2013).

200. Council for Trade-Related Aspects of Intellectual Property Rights, Extension of the Transition Period Under Article 66.1 of the TRIPS Agreement for Least Developed Country Members for Certain Obligations with Respect to Pharmaceutical Products, WTO Doc. IP/C/73 (Nov. 6, 2015).

201. See Yu, Enforcement, Economics and Estimates, supra note 145, at 2-6 (discussing the costs of strong intellectual property enforcement norms and the resulting trade-offs). 
development of his [or her] personality" are to be realized "in accordance with the organization and resources of each State."202 Likewise, Article 2(1) of the ICESCR provides:

Each State Party to the present Covenant undertakes to take steps, individually and through international assistance and co-operation, especially economic and technical, to the maximum of its available resources, with a view to achieving progressively the full realization of the rights recognized in the present Covenant by all appropriate means, including particularly the adoption of legislative measures. ${ }^{203}$

In an earlier article, I advanced the progressive realization approach to address the fact that countries may not initially have sufficient resources to offer protection beyond their minimum core obligations. ${ }^{204}$ Under the ICESCR, contracting parties are required to provide the "minimum essential levels" of protection of all of the human rights covered. ${ }^{205}$ Once they have satisfied these minimum core obligations, they have to take "deliberate, concrete and targeted" steps toward the full realization of the rights covered. ${ }^{206}$

Finally, it may be useful to examine human rights protection in relation to the changing technological contexts. With the arrival of the Internet and other new communications technologies, new questions about human rights protection have arisen, and will continue to emerge. ${ }^{207}$ If we are to properly understand the human

202. UDHR, supra note 1, art. 22.

203. ICESCR, supra note 9, art. 2(1).

204. See Yu, Reconceptualizing Intellectual Property Interests, supra note 18, at 1113-23 (advancing the progressive realization approach).

205. See Comm. on Econ., Soc. \& Cultural Rights, General Comment No. 3: The Nature of States Parties Obligations (Art. 2, Par. 1), 11 , U.N. Doc. E/1991/23 (Dec. 14, 1990) [hereinafter General Comment No. 3] ("A] minimum core obligation to ensure the satisfaction of, at the very least, minimum essential levels of each of the rights is incumbent upon every State party."); see also Chapman \& Russell, supra note 190, at 9 (defining "minimum essential levels" as "the essential element or elements without which [a right] loses its substantive significance as a human right and in the absence of which a State party should be considered to be in violation of its international obligations").

206. General Comment No. 3, supra note 205, If 2; see also ICESCR, supra note 9, art. 2(1) (requiring each state party "to take steps . . to the maximum of its available resources, with a view to achieving progressively the full realization of the rights recognized in the present Covenant by all appropriate means, including particularly the adoption of legislative measures"); MATTHEW C.R. CRAVEN, THE INTERNATIONAL COVENANT ON ECONOMIC, SoClal, AND Cultural Rights: A Perspective on ItS Development 136-44 (1995) (discussing the phrase "to the maximum of its available resources" in the ICESCR).

207. See Land, Toward an International Law, supra note 24, at 399 ("[T] he human rights protections that apply generally to all restrictions on freedom of expression and information apply equally to communication and the exchange of information online."). 
rights aspects of intellectual property rights, we will need to develop a better understanding of how human rights are to be protected in changing technological contexts.

The need for such an understanding does not mean that human rights protection should vary according to technological environments. Rather, the changing contexts remind us that human rights obligations may be realized through different means. After all, international and regional human rights instruments rarely mandate specific modalities for protecting the human rights concerned. In earlier works, I discussed how this right can be protected by other models, such as "grants, subsidies, prizes, advance market commitments, reputation gains, open source drug discovery, patent pools, and public-private partnerships." 208

Because of the limited space available, this part does not have room to provide illustrations from political science, sociology, cultural studies, and other disciplines. Nevertheless, it is worth recalling that human rights research is interdisciplinary by nature. ${ }^{209}$ As such, it can be enriched by insights gleaned from a broad array of disciplines. The need for inter- and multi-disciplinary learning and research is indeed the reason why contextual analyses are highly important in the area of intellectual property and human rights.

\section{Summary}

This part has highlighted the emergence of a growing body of scholarship on human rights methods and methodology. It has also

208. Yu, Nonmultilateral Era, supra note 23, at 1077-78; Yu, Anatomy, supra note 18, at 62-63; see also Special Rapporteur's Report on Patent Policy, supra note 17, If 57 ("Alternative mechanisms have long existed alongside patents to stimulate research. These include tax incentives for corporate investments in research and development, public funding for scientific research, government purchasing, prize competitions and advance market commitments."); Rochelle Cooper Dreyfuss, Patents and Human Rights: Where Is the Paradox?, in A PARADOX, supra note 20, at 81 ("Other methods of assuring payment include lead time advantages, government or private contracts and research grants, contests, bonuses, prizes, tenure, and professorial chairs."); GENE PATENTS AND COLLABORATIVE LiCENSING MODELS: PATENT PoOls, CleARINGHouses, OPEN SOURCE MODELS AND LIABILITY REGIMES (Geertrui Van Overwalle ed., 2009) (collecting articles that discuss patent pools, clearinghouses, open source models, and liability regimes); INCENTIVES FOR GLOBAL PUBLIC HEALTH: PATENT LAW AND ACCESS to Essential Medicines 133-283 (Thomas Pogge et al. eds., 2010) (collecting articles that discuss prizes, patent pools, and open source drug discovery).

209. See supra note 188 (collecting sources that highlight the interdisciplinarity of human rights research). 
shown that many different methods can be used to support research on intellectual property and human rights. At the outset, it is worth remembering that none of the research methods discussed in this article or elsewhere in the methodological literature would be superior. Whether one method will work better than the others will depend on the research tasks at hand, the researcher's background, experience and interests, the duration of the research project, and funding and other resources available for that project. ${ }^{210}$

Moreover, researchers have increasingly deployed multiple methods to conduct human rights research. ${ }^{211}$ As Fons Coomans, Fred Grünfeld, and Menno Kamminga observed:

There is ... not a single, preferred research method. There also is no typical, preferred method for carrying out research in the field of human rights. The method chosen to answer a given research question may, for example, be quantitative or qualitative, inductive or deductive, a case study or an attempt to draw general conclusions, covering just one country or comparing more countries, be based merely on written sources ("desk top research") or on field study and interviews.

210. See Andreassen, supra note 126, at 238 ("The methodological choices that any researcher has to make are informed by research questions, theories applied and the epistemological orientation of the researcher."); Andreassen et al., supra note 31, at 4 ("The choice of methods depends on the research question posed."); Coomans et al., supra note 123, at 15 ("The method chosen for a research project should follow logically from the project's research question. It may also depend on such practical considerations as the information, the financial resources and the time that is available, as well as the qualifications of the researcher."); Landman, supra note 127 , at 41 ("[T]here is not one preferred [research] method, since method is a function of the epistemological orientations of the researcher, the theoretical perspective that is adopted, the nature of the research question, as well as the available time and material resources with which to carry out any research project."); McConnell \& Smith, supra note 124, at 163-64 ("Research choices] may be influenced by who is commissioning the research, the purpose of the research and/or the practicalities of the resources available-money, staff and so on. ... In human rights research, the choice of methods may [also] be influenced by the intended recipient of the research.").

211. As Rhona Smith and Lee McConnell observed:

While certain combinations of methods will be more compatible than others, it is clear that methods in human rights research rarely operate in a vacuum. Instead, researchers are often prone to adopt a mixed approach, where different methods are blended to ensure the research questions are fully addressed, or to account for certain sub-questions, the answers to which are relevant to the understanding of the research area as a whole. This can produce more credible results as a degree of "testing" is inbuilt by using a second or third method to corroborate or crosscheck findings, or to reach a more holistic, deeper understanding of the field of study with which the primary research question is concerned.

McConnell \& Smith, supra note 124, at 150. 
A combination of methods, if expertly employed, may of course produce more reliable results. ${ }^{212}$

The research methods discussed in this article, for instance, are not mutually exclusive. Part II.B noted the benefit of combining comparative methods with quantitative assessments to provide cross-country analyses of the human rights aspects of intellectual property rights. Part II.C further suggested that comparative methods and quantitative assessments can be utilized to analyze human rights in specific contexts. Combining all three types of research methods would help yield a holistic examination of the interrelationship between intellectual property and the specific human rights involved.

The goal of this part is not to provide a comprehensive discussion of all the different methods that can be used to conduct research on intellectual property and human rights. Rather, it is to call on researchers to pay greater attention to the methods used. In doing so, these researchers will be better positioned to recognize the strengths and weaknesses of their chosen methods. They will also be able to explore further whether those methods have unduly influenced the outcome of their analyses. In some circumstances, it will indeed be helpful to explain not only why the researchers have chosen specific methods, but also why they have not used other equally valid and applicable methods. ${ }^{213}$

It is my hope that a greater emphasis on methodological rigor will lead to new and more robust research on intellectual property and human rights. In doing so, scholars in this intersectional area will be able to build on the past two decades of scholarship to push

212. Coomans et al., supra note 123, at 15; see also Andreassen, supra note 126, at 238 ("In principle, there is no one preferred method in comparative research."); Andreassen et al., supra note 31, at 4 ("Among generally recognized methods, no single method is 'better' than others, although disagreement about the robustness of results arising from different methods certainly exists."); Langford, supra note 156, at 161 ("[H]uman rights constitutes a natural field for interdisciplinary endeavour and methodological heterogeneity."); Smith \& McConnell, supra note 128, at 5 ("Any single method has its limitations and strengths. Different research questions and different funders require different methods to be used. Perhaps unsurprisingly, a lot of human rights research thus follows a mixed approach.").

213. See Coomans et al., supra note 123, at 15-16 ("The description of the method adopted should also discuss which alternative methods have been considered and why these have been rejected. The purpose here is to demonstrate that the researcher has reflected on the proper method of research for the project and has made a choice that is justifiable."); see also McConnell \& Smith, supra note 124, at 164 ("Mixing methods can be trial and error, but there remains a need for careful forethought, planning and a logical narrative to ensure that the question or phenomenon is explored in the best way."). 
for new research frontiers. Greater methodological rigor and curiosity will also help expand the toolbox now available to researchers in the area of intellectual property and human rights. ${ }^{214}$

\section{Why StUdy INTELLECTUAL PROPERTY AND HUMAN RIGHTS?}

The previous part has discussed three methods that have been widely used to conduct research on intellectual property and human rights. That discussion has made implicit the assumption that undertaking research in this area is important. The logical followup question, then, is: Why do we need to conduct such research in the first place? This inquiry is similar to the usual question posed to human rights educators concerning why they study human rights. Because a growing literature already exists on human rights education, ${ }^{215}$ this part does not attempt to answer this broad question. Instead, it narrows the inquiry's focus to the area of intellectual property and human rights. This part further outlines the various contributions a robust debate in this area can provide to the intellectual property regime, the human rights regime, and the interface between these two regimes.

\section{A. Intellectual Property}

For many policymakers and commentators in the intellectual property field, especially those alarmed by the fundamental conflicts between human rights and intellectual property rights, the answer to the "why" question begins with the important limits human rights have placed on the protection and enforcement of intellectual property rights. In the copyright area, the right to freedom of opinion and expression restrains the overzealous protection and enforcement of intellectual property rights. As the United States

214. See McConnell \& Smith, supra note 124, at 164 ("Ultimately, human rights research methods can best be viewed as a toolbox - the more methods and approaches available, the easier it is to select the best options for a particular project."); see also Andreassen et al., supra note 31 , at 4 ("Training in methods is essentially about building skills to develop robust research questions and make good choices about which method or methods to use, and how to apply the methods effectively once chosen. It also entails training in understanding how those choices relate to particular paradigms, values or theoretical premises.").

215. See supra note 32 (collecting sources that discuss human rights education). 
Supreme Court noted in Eldred v. Ashcroft, ${ }^{216}$ the First Amendment provides the much-needed "built-in ... accommodations" to ensure a well-functioning copyright system. ${ }^{217}$

In the patent area, the right to life and the right to health, like the right to freedom of opinion and expression, have also provided important external constraints, ${ }^{218}$ especially in relation to fostering access to medicines and medical technologies. ${ }^{219}$ To address the public health pandemics in Sub-Saharan Africa, WTO members agreed to develop the so-called "Paragraph 6" solution to enable countries with insufficient or no manufacturing capacity to import

216. 537 U.S. 186 (2003).

217. Id. at 219-20; see also Campbell v. Acuff-Rose Music, Inc., 510 U.S. 569, 579 (1994) (noting "the fair use doctrine's guarantee of breathing space within the confines of copyright").

218. See Geertrui Van Overwalle, Human Rights' Limitations in Patent Law, in A PARADOX, supra note 20, at 236 (discussing the human rights limitations in patent law); see also Carlos M. Correa, Mitigating the Impact of Intellectual Property in Developing Countries Through the Implementation of Human Rights, in RESEARCH HANDBOOK, supra note 20 , at 201 (discussing the use of human rights obligations to mitigate the impact of high intellectual property standards in developing countries); Christophe Geiger, Fundamental Rights, A Safeguard for the Coherence of Intellectual Property Law?, 35 INT'L REV. INTELL. PROP. \& COMPETITION L. 268, 278 (2004) ("[Fundamental rights] can serve as a corrective when the rights are used excessively and contrary to their functions.").

219. See, e.g., Obijiofor Aginam, Communitarian Globalism and Disease: A Normative Orientation for Global Health Governance, in THE GLOBAL GOVERNANCE OF HIV/AIDS: INTELLECTUAL PROPERTY AND ACCESS to ESSENTTAL MEDICINES 14, 19-21 (Obijiofor Aginam, John Harrington \& Peter K. Yu eds., 2013) [hereinafter GlOBAL GoverNANCE OF HIV/AIDS] (discussing the "human rights versus intellectual property rights" debate); Carlos Correa \& DUNCAN MatThews, The DoHa DeClaration Ten Years on and ITS IMPACT ON ACCESS TO MEDICINES AND THE RIGHT TO HEALTH (2011), http://www. undp.org/content/undp/en/home/librarypage/hiv-aids/doha10yearson.html [https://perma.cc /G87X-UZHE] (discussing the impact of the Doha Declaration on the TRIPS Agreement and Public Health on access to medicines and the right to health); James Harrison, Trade Agreements, Intellectual Property and Access to Essential Medicines: What Future Role for the Right to Health?, in GLOBAL GOVERNANCE OF HIV/AIDS, supra, at 87 (discussing the role of right to health in HIV/AIDS governance); Duncan Matthews, Intellectual Property Rights, Human Rights and the Right to Health, in A PARADOX, supra note 20, at 118 (examining the tensions between intellectual property rights, human rights, and the right to health); Duncan Matthews, Right to Health and Patents, in RESEARCH HANDBOOK, supra note 20, at 496 (mapping the rights-based discourse on the interface between the right to health and patents); Lisa Forman, "Rights" and Wrongs: What Utility for the Right to Health in Reforming Trade Rules on Medicines?, 10 HEALTH \& HUM. RTS. 37, 37 (2008) ("[T] he AIDS medicine experience and the seminal corporate litigation in South Africa in 2001, in particular, point to the transformative potential of the right to health to raise the priority of public health needs in trade-related intellectual property rights, and to advance access to critical health interventions in resource-poor settings."); Ruth L. Okediji, Does Intellectual Property Need Human Rights?, 51 N.Y.U. J. INT'L L. \& POL., 1, 8 (2018) [hereinafter Okediji, Human Rights] ("[]n the context of the right to health, this linkage has considerable merit when considering the importance of these actors to outcomes such as the Doha Declaration, as well as other ongoing gains in the area of access to essential medicines." (footnote omitted)). 
generic versions of patented pharmaceuticals. 220 This solution eventually became the proposed Article 31bis of the TRIPS Agreement, ${ }^{221}$ which was adopted in January 2017 after it had been opened for ratification for more than a decade. ${ }^{222}$

The second contribution is that a robust discourse on human rights in the intellectual property area will help develop a better understanding of the nature of intellectual property rights. This discourse will show that these rights are not self-evident by nature. ${ }^{223}$ Oftentimes, the intellectual property system grants protection based on demands from intellectual property industries and their powerful and supportive governments. ${ }^{224}$ As a result, the level of protection provided by intellectual property laws are

220. See General Council, Implementation of Paragraph 6 of the Doha Declaration on the TRIPS Agreement and Public Health, WTO Doc. WT/L/540 (Sept. 1, 2003); World Trade Organization, Declaration on the TRIPS Agreement and Public Health, WTO Doc. W'T/MIN(01)/DEC/2, 41 I.L.M. 755, 756 (2002) (recognizing that "WTO Members with insufficient or no manufacturing capacities in the pharmaceutical sector could face difficulties in making effective use of compulsory licensing under the TRIPS Agreement"); Peter K. Yu, The International Enclosure Movement, 82 IND. L.J. 827, 872-86 (2007) (discussing the Doha Declaration, the August 30 decision of the Council for Trade-Related Aspects of Intellectual Property Rights, and the proposed Article $31 \mathrm{bis}$ of the TRIPS Agreement).

221. General Council, Amendment of the TRIPS Agreement, WTO Doc. WT/L/641 (Dec. 8, 2005).

222. See Press Release, World Trade Org., WTO IP Rules Amended to Ease Poor Countries' Access to Affordable Medicines (Jan. 23, 2017), https:/www.wto.org/english/news _e/news17_e/trip_23jan17_e.htm [https://perma.cc/5TVS-FXZD] (announcing that the proposed Article 31 bis entered into force).

223. See Rosemary J. CoOmbe, The Cultural life of Intellectual Properties: AUTHORSHIP, APPROPRIATION, AND THE LAW 247 (1998) ("The range of Western beliefs that define intellectual and cultural property laws ... are not universal values that express the full range of human possibility, but particular, interested fictions emergent from a history of colonialism that has disempowered many of the world's peoples."); William P. Alford, How Theory Does-and Does Not-Matter: American Approaches to Intellectual Property Law in East Asia, 13 UCLA PAC. BASIN L.J. 8, 17 (1994) ("[F]ar from being universal, it is the ideas of ownership embedded in modern Western intellectual property that are the historical aberrations, and that these ideas have achieved the currency they now enjoy internationally as much because they are backed by great economic might as because of their appeal to our common sense or their innate conceptual force."); Peter K. Yu, From Pirates to Partners: Protecting Intellectual Property in China in the Twenty-First Century, 50 AM. U. L. REV. 131, 235 (2000) ("Adherents of the realist theory of international relations will find even more unconvincing the argument that the Western intellectual property regime represents universal values.").

224. See generally DUNCAN MATTHEWS, Globalising INTELLECTUAL PROPERTy Rights: THE TRIPS AGREEMENT (2002) (examining the role of the industries in the TRIPS negotiations); Susan K. Sell, PrIvate Power, Public Law: The Globalization of InTellectual PROPERTY RIGHTS 96-120 (2003) (discussing the role of the Intellectual Property Committee in pushing for the adoption of high intellectual property standards in the TRIPS Agreement). 
higher, and often much higher, than the levels required by international or regional human rights instruments. As I noted in earlier articles, as far as the protection of material interests is concerned, the UDHR and the ICESCR merely require that authors be "enable[d] . . to enjoy an adequate standard of living." $225 \mathrm{Gen}$ eral Comment No. 17 further underscored the considerable difference between what is protected under the ICESCR and what is protected under international trade and intellectual property agreements:

\begin{abstract}
Whereas the human right to benefit from the protection of the moral and material interests resulting from one's scientific, literary and artistic productions safeguards the personal link between authors and their creations and between peoples, communities, or other groups and their collective cultural heritage, as well as their basic material interests which are necessary to enable authors to enjoy an adequate standard of living, intellectual property regimes primarily protect business and corporate interests and investments. Moreover, the scope of protection of the moral and material interests of the author provided for by article 15, paragraph 1 (c), does not necessarily coincide with what is referred to as intellectual property rights under national legislation or international agreements. ${ }^{226}$
\end{abstract}

Even if human rights obligations do require the protection of some of the existing intellectual property rights, or some aspects of those rights, these obligations do not extend to all of those rights, or all aspects of those rights. ${ }^{227}$ Nor do human rights obligations

225. General Comment No. 17, supra note 8, ๆ 2; see also CRAVEN, supra note 206, at 287-351 (discussing the "right to an adequate standard of living"); HELFER \& AUSTIN, supra note 19, at 189 (noting that "material interests" in the right to the protection of the moral and material interests resulting from intellectual production "are . . . tied to the ability of creators to enjoy an adequate standard of living"); cf. ICESCR, supra note 9, art. 11(1) (recognizing "the right of everyone to an adequate standard of living for himself and his family, including adequate food, clothing and housing, and to the continuous improvement of living conditions").

226. General Comment No. 17, supra note 8, ๆ 2; see also Helfer, Human Rights Framework, supra note 18, at 996 (noting that General Comment No. 17 suggested "the existence of an irreducible core of rights-a zone of personal autonomy in which authors can achieve their creative potential, control their productive output, and lead independent, intellectual lives, all of which are essential requisites for any free society").

227. See Special Rapporteur's Report on Copyright Policy, supra note 17, I 26 ("Some elements of intellectual property protection are indeed required-or at least strongly encouraged - by reference to the right to science and culture. Other elements of contemporary intellectual property laws go beyond what the right to protection of authorship requires, and may even be incompatible with the right to science and culture."); Sam Ricketson, Intellectual Property and Human Rights, in COMMERCIAL LAW AND HUMAN RIGHTS 187, 212 (Stephen Bottomley \& David Kinley eds., 2002) ("Many, though by no means all, of the rights protected under IP laws can claim a foundation in the human rights obligations contained 
require that intellectual property rights be protected under the oftused property model, which is neither the best nor the only model for such protection. ${ }^{228}$ As the CESCR made clear in General Comment No. 17, the ICESCR does not speak to the modalities of protection concerning the right to the protection of the moral and material interests resulting from intellectual production. ${ }^{229}$ State parties therefore have wide discretion to determine how this right is to be protected.

The third contribution is that a robust human rights discourse in the intellectual property area will help illustrate the difficult challenge of striking an appropriate balance in the intellectual property system. Although commentators often underscore the importance of balance, balance cannot be struck without a deep and thorough understanding of the local environment. As Daniel Gervais rightly reminded us, "[b]alance . . is not, contrary to what one often reads or hears in policy debates concerning intellectual prop-

in articles 27(2) of the Universal Declaration and 15(1)(c) of the ICESCR, but these claims need to be balanced against other rights that may be invoked by third parties."); Yu, Nonmultilateral Era, supra note 23, at 1048 (underscoring "the importance of distinguishing the human rights attributes of intellectual property rights from the non-human rights aspects of intellectual property protection"); Yu, Reconceptualizing Intellectual Property Interests, supra note 18, at 1077 ("[S]ome attributes of intellectual property rights are protected in international or regional human rights instruments, while other attributes do not have any human rights basis at all"); Peter K. Yu, Ten Common Questions About Intellectual Property and Human Rights, 23 GA. ST. U. L. REV. 709, 710-11 (2007) [hereinafter Yu, Ten Common Questions] ("[S]ome attributes of intellectual property rights are protected in international or regional human rights instruments while other attributes do not have any human rights basis at all." (emphasis omitted)).

228. See Yu, Reconceptualizing Intellectual Property Interests, supra note 18, at 1089 ("IA] property-based regime is not the only acceptable modality of protection that can be used to realize the right to the protection of material interests in intellectual creations. Nor is it the best. Instead, it merely provides an option.").

229. As the CESCR stated:

The term of protection of material interests under article 15, paragraph 1(c), need not extend over the entire lifespan of an author. Rather, the purpose of enabling authors to enjoy an adequate standard of living can also be achieved through one-time payments or by vesting an author, for a limited period of time, with the exclusive right to exploit his scientific, literary or artistic production.

General Comment No. 17, supra note 8, I 16; see also Torremans, Copyright, supra note 35, at 229 ("[A] lot of freedom is left to Contracting States in relation to the exact legal format of [the] protection [for the interests of authors and creators]."); Yu, Reconceptualizing Intellectual Property Interests, supra note 18, at 1088-92 (discussing the different acceptable modalities of protection that can be used to realize the right to the protection of interests in intellectual creations). 
erty, a simple axis with rights holders at one end and users of intellectual property on the other." 230 Indeed, similar challenges can be found in efforts to strike an appropriate balance between human rights and intellectual property rights. Striking a balance between the human rights aspects of intellectual property rights and other human rights will require considerable effort, careful assessment, and innovative approaches. ${ }^{231}$

Indeed, different countries will need different intellectual property laws and policies. Such a need is in part why policymakers and commentators have heavily criticized the one-size-fits-all regime-or, more precisely, the supersize-fits-all regime-now enshrined in the TRIPS Agreement and TRIPS-plus bilateral, regional, and plurilateral trade agreements. ${ }^{232}$ Commentators have also noted how countries with strong control of information, or

230. Daniel J. Gervais, TRIPS and Development, in INTELleCtUAL PROPERTy, TRADE AND DEVELOPMENT: STRATEGIES TO OPTIMIZE ECONOMIC DEVELOPMENT IN A TRIPS-PLUS ERA 49 (Daniel J. Gervais ed., 1st ed. 2007) [hereinafter INTELlECTUAL PROPERTY, TRADE AND DEVELOPMENT].

231. As I noted in an earlier article:

Thus far, commentators have employed different approaches to resolve these conflicts. For example, they have discussed the distinction between true conflicts and false conflicts, drawing on conflict-of-law jurisprudence and scholarship. They have also explored the use of hierarchies, balancing techniques, the proportionality doctrine, and interpretations by reference to external normssuch as scientific norms in relation to the right to enjoy the benefits of scientific progress and its applications. In addition, the Ontario Human Rights Commission introduced a Policy on Competing Human Rights, which outlines a process for reconciling competing human rights claims and providing case-by-case accommodation of individual and group rights. In an earlier work, I also outlined three different approaches that can be used to resolve these conflicts: (1) just remuneration; (2) core minimum; and (3) progressive realization. Under the just remuneration approach, for instance, authors and inventors hold a right to remuneration (rather than exclusive control) while individuals obtain a human rights-based compulsory license (as opposed to a free license).

Yu, Anatomy, supra note 18, at 76-80 (footnotes omitted).

232. See Shamnad Basheer \& Annalisa Primi, The WIPO Development Agenda: Factoring in the "Technologically Proficient" Developing Countries, in IMPLEMENTING THE WORLD INTELlECTUAL PROPERTY ORganization's DEVElopMENT AGENDA 100, 110 (Jeremy de Beer ed., 2009) [hereinafter IMPLEMENTING WIPO's DEVELOPMENT AGENDA] (alluding to the “one-'super-size'-fits-all model"); Jeremy de Beer, Defining WIPO's Development Agenda, in IMPLEMENTING WIPO'S DEVELOPMENT AGENDA, supra, at 1, 3 (referring to "a one-size, especially a supersize, model of global IP law"); James Boyle, A Manifesto on WIPO and the Future of Intellectual Property, DukE L. \& TECH. REV., Sept. 8, 2004, at 4 ("One size fits all. And it is 'extra large."'); Peter K. Yu, The Global Intellectual Property Order and Its Undetermined Future, 1 WIPO J. 1, 9 (2009) (noting the problems raised by a "super-size-fits-all model"). 
those transitioning from a Soviet past, will need a different copyright system. ${ }^{233}$ Scrutinizing intellectual property law and policy through a human rights lens will help us understand the potential interaction of these laws and policies "with the economic, political, and social particularities of different nation states." 234

The final contribution is that a robust human rights discourse in the intellectual property area will provide the much-needed rhetorical force to help strengthen limitations, safeguards, and flexibilities in the intellectual property system. ${ }^{235}$ Such rhetoric is particularly powerful at the international level. ${ }^{236}$ Thus far, many

233. See Neil Weinstock Netanel, Asserting Copyright's Democratic Principles in the Global Arena, 51 VAND. L. REV. 217, 277-78 (1998) (arguing that "copyright should be carefully tailored to give greater potency to its support of democratization and to minimize the barriers that it may pose under various local conditions" and that "it may be more conducive to democratic development to allow for a good measure of compulsory licensing, with royalties set to enable widespread access, while also providing some remuneration to copyright owners"); Peter K. Yu, Moral Rights 2.0, 1 TEX. A\&M L. REV. 873, 891 (2014) ("In countries with heavy censorship, ... Internet users often will need to reuse, without permission, materials previously approved by censors or that are only available abroad. To provide an alternative source of information, they may need to repost copyrighted stories, videos, or photos that otherwise would not have been available. They may also need to repurpose preexisting materials to address issues that they otherwise cannot discuss because of government censorship."); Peter K. Yu, Promoting Internet Freedom Through the Copyright System, EJOURNAL USA, June 2010, at 7 (discussing the need to adjust the balance of the copyright system to reflect the different political and social conditions in countries where information flows have been heavily regulated).

234. See HELFER \& AUSTIN, supra note 19, at 359 ("Scrutinizing copyright through a human rights lens, with an appropriate sensitivity to the duties imposed by the subsistence of copyright, directs attention to how the burdens imposed by these duties intersect with the economic, political, and social particularities of different nation states.").

235. As Holger Hestermeyer asked rhetorically:

Do not human rights norms "recognize" rather than "create" human rights, pointing to a right pre-existing in nature, or maybe a transcendental notion of the aspirations that we all carry inside? Would not a legislator lose its legitimacy if it decided to disregard these norms? Is it not all but natural to grant norms that guarantee the freedoms and needs of individuals precedence over norms that are merely instrumental and serve these goals only indirectly? As an aspiration and goal at this abstract level this thought is almost impossible not to agree with.

HESTERMEYER, supra note 21, at 204 (footnotes omitted).

236. As Professors Helfer and Austin observed:

From a negotiating perspective, reform arguments that draw upon the output of these human rights venues have a distinct strategic advantage. They invoke legal rules and norms adopted by institutions whose provenance and legitimacy are well established and that have received the imprimatur of many governments in other international fora. By drawing upon these sources, reform advocates can more credibly claim that a rebalancing of intellectual property protection rules is necessary to harmonize two parallel regimes of internation- 
developing countries have utilized human rights arguments to push for these limitations, safeguards, and flexibilities, which they hope will be transformed into "ceilings," or maximum limits, to curtail the further expansion of intellectual property rights. ${ }^{237}$ To be sure, the development imperative can provide some helpful justification for these limitations, safeguards, and flexibilities. ${ }^{238}$ Nevertheless, development-based arguments do not have the same rhetorical pull as human rights arguments. While the former invokes sentiments relating to altruism and humanitarian assistance, the latter calls for equality and respect for human dignity.

ally recognized "rights." And they can more easily deflect claims that such rebalancing efforts are merely fig leaves for self-serving legislation by well-resourced user industries or disguised attempts to distort free trade rules or free ride on foreign creators and inventors.

HeLFER \& AUSTIN, supra note 19, at 510; see also Willem Grosheide, General Introduction, in A PARADOX, supra note 20, at 3, 5 ("Strategically, [the view that human rights are perceived as a countervailing force against intellectual property rights] is often used during international trade negotiations in order to weaken the position of the developed world."); Christophe Geiger, "Constitutionalizing" Intellectual Property Law? The Influence of Fundamental Rights on Intellectual Property in the European Union, 37 INT'L REV. INTELL. PROP. \& COMPETITION L. 371, 382 (2006) ("It is thus becoming urgent to give IP law a new legitimacy and to ensure the reconciliation of interests by searching for a new foundation for the system. In our opinion, fundamental rights and human rights can offer a suitable basis for a balanced system." (footnote omitted)). But see Ruth L. Okediji, The Limits of Development Strategies at the Intersection of Intellectual Property and Human Rights, in INTELLECTUAL PROPERTY, TRADE AND DEVELOPMENT, supra note 230, at 355, 370-71 thereinafter Okediji, Limits of Development Strategies] ("[T] he limitations of the human rights narrative are amplified when we move from the context of essential medicines and access to drugs to the relatively banal and non-life-threatening domain of literary and artistic works.").

237. See Annette Kur \& Henning Grosse Ruse-Khan, Enough Is Enough-The Notion of Binding Ceilings in International Intellectual Property Protection, in INTELLECTUAL PROPERTY RIGHTS IN A FAIR WORLd TRAde SYSTEM: PROPOSALS FOR REFORM OF TRIPS 359, 359 (Annette Kur with Marianne Levin eds., 2011) (calling for the development of mandatory ceilings in intellectual property law and policy); Graeme B. Dinwoodie, Federalized Functionalism: The Future of Design Protection in the European Union, 24 AIPLA Q.J. 611, $715 \mathrm{n} .274$ (1996) (advancing the concept of "binding 'substantive maxima"); Rochelle Cooper Dreyfuss, TRIPS-Round II: Should Users Strike Back?, 71 U CHI. L. REV. 21, 27 (2004) ("The WTO system must begin to recognize substantive maxima on the scope of available protection...."); Ruth Okediji, Toward an International Fair Use Doctrine, 39 CoLUM. J. TRANSNAT'L L. 75, 168 (2000) (proposing to develop an international fair use doctrine as a "ceiling"); Peter K. Yu, TRIPs and Its Discontents, 10 MARQ. INTELL. Prop. L. REV. 369, 402 (2006) ("The international intellectual property regime, to some extent, is handicapped by its lack of maximum standards.").

238. See Peter K. Yu, Five Decades of Intellectual Property and Global Development, 8 WIPO J. 1, 4-7 (2016) [hereinafter Yu, Five Decades] (discussing the ongoing efforts to realize the U.N. Sustainable Development Goals in the intellectual property arena while drawing insights from the development of the Declaration on the Right to Development). 
Moreover, as Mary Ann Glendon pointed out, "rights talk," for both good and bad, generates its own power and dynamics. ${ }^{239}$ When a right is characterized as a human right, such characterization "often invokes... a language of trumps and unconditional demands." 240 Considering the wide recognition of human rights before the adoption of the UDHR and the continuing controversy surrounding the right to development, ${ }^{241}$ which was first articulated in 1972 but did not emerge until December 1986, ${ }^{242}$ human rights arguments have certainly provided more rhetorical force and persuasive power than development-based arguments.

\section{B. Human Rights}

Although the literature on intellectual property and human rights has at times highlighted the benefits of a robust human rights discourse in the intellectual property area, little, if any, of this literature has highlighted the contributions provided by a robust intellectual property discourse in the human rights area. This subpart therefore turns to these contributions.

The first contribution is that a robust discourse on intellectual property and human rights will highlight the immense challenge of balancing the different types of human rights. Those who consider intellectual property as human rights, or emphasize the property aspects of intellectual property rights, will view conflicts between human rights and intellectual property rights as endogenous conflicts within the human rights regime. ${ }^{243}$ As a result, policymakers, commentators, and activists will need to find ways to balance these equally important rights. ${ }^{244}$ After all, like

239. See also Forman, supra note 219, at 45 ("Rights-based discourse, litigation, and action appear to have played significant roles in shifting policy, price, and perception around AIDS medicines."). See generally MARY ANn GLENDON, Righ'Ts TALK: THE IMPOVERISHMENT OF POLITICAL Discourse (1991) (discussing the dynamics of "rights talk" and how such talk has impoverished the American political discourse).

240. HELFER \& AUSTIN, supra note 19, at 504.

241. See generally Abdel-Latif, supra note 93 (discussing the right to development as part of the interface between intellectual property and human rights); Yu, Five Decades, supra note 238, at 4-10 (discussing insights that the right to development has provided to the intellectual property area and advancing observations on intellectual property and global development).

242. Okediji, Limits of Development Strategies, supra note 236, at 360 .

243. See supra note 77 (collecting sources that discuss the use of the right to private property to provide an alternative human rights basis for intellectual property rights).

244. See Yu, Anatomy, supra note 18, at 76-80 (discussing the different approaches to 
other human rights, intellectual property rights are intended to be "universal, indivisible and interdependent and interrelated." 245

Even for those who do not take such a strong human rightsbased approach to intellectual property rights, they admit that some aspects of intellectual property rights have human rights bases. Because of this overlap, it is important to separate the human rights aspects of intellectual property rights from their non-human rights aspects. ${ }^{246}$ Thus, a robust discourse on intellectual property and human rights will help us think more deeply about the different ways to address the internal tensions and conflicts within the human rights system. Such a discourse will also help us devise new principles, mechanisms, and institutions to resolve these tensions and conflicts.

The second contribution is that a robust discourse on intellectual property and human rights will enable us to revisit the continuous-and, for some, unwanted-debate on a potential hierarchy of human rights. Although Paragraph 5 of the Vienna Declaration and Programme of Action stated explicitly that "[a]ll human rights are universal [and] indivisible," 247 some commentators still have a tendency to separate the different types of human rights based on whether they belong to the first, second, or third generation. ${ }^{248}$ For

resolve the conflicts between the human rights aspects of intellectual property rights and other human rights).

245. World Conference on Human Rights, Vienna Declaration and Programme of Action, I| 5, U.N. Doc. A/CONF.157/23 (June 25, 1993) [hereinafter Vienna Declaration].

246. See Yu, Digital Copyright Enforcement Measures, supra note 24, at 461 (noting the need to "engag[e] in a proper analysis of the conflicts between intellectual property rights and the non-human rights aspects of intellectual property rights"); Yu, Nonmultilateral Era, supra note 23, at 1048 (underscoring "the importance of distinguishing the human rights attributes of intellectual property rights from the non-human rights aspects of intellectual property protection").

247. Vienna Declaration, supra note 245 , ๆ 5.

248. As Matthew Craven explained:

That economic, social, and cultural rights have been identified as a discrete category of human rights is most usually explained in terms of their distinct historical origin. Economic, social, and cultural rights are frequently termed "second generation" rights, deriving from the growth of socialist ideals in the late nineteenth and early twentieth centuries and the rise of the labour movement in Europe. They contrast with the "first generation" civil and political rights associated with the eighteenth-century Declarations on the Rights of Man, and the "third generation" rights that encompass the rights of "peoples" or "groups", such as the right to self-determination and the right to development. In fact the reason for making a distinction between first and second generation rights could be more accurately put down to the ideological conflict between East and West pursued in the arena of human rights during the drafting 
many decades, countries in the developed West have also privileged civil and political rights over economic, social, and cultural rights. ${ }^{249}$

Because the right to the protection of the moral and material interests resulting from intellectual production is a socio-economiccultural right that falls within the second generation, any discussion of that right, and the interplay of that right and other human rights, will require scholars to think more deeply about the appropriate treatment of social, economic, and cultural rights. ${ }^{250}$ In ad-

\begin{abstract}
of the Covenants. The Soviet States, on the one hand, championed the cause of economic, social, and cultural rights, which they associated with the aims of the socialist society. Western States, on the other hand, asserted the priority of civil and political rights as being the foundation of liberty and democracy in the "free world". The conflict was such that during the drafting of the International Bill of Rights the intended treaty was divided into two separate instruments which were later to become the ICCPR and the ICESCR.
\end{abstract}

CRAVEN, supra note 206, at 8-9 (footnotes omitted); see also Asbjorn Eide \& Allan Rosas, Economic, Social and Cultural Rights: A Universal Challenge, in ECONOMIC, SOCIAL AND CUltural RIGHTS: A TEXTBOOK 15, 15-16 (Asbjørn Eide et al. eds., 1995) (discussing use of the terms "first generation," "second generation," and "third generation" to distinguish between different types of human rights); HELFER \& AUSTIN, supra note 19, at 13 ("As a practical matter ..., the formal equality of the two generations of rights masks a deeper debate over competing conceptions of state responsibility to satisfy basic human needs. The drafters of the ICESCR and the ICCPR intended both treaties to be acceptable to socialist states, developing nations, and industrialized free-market countries. But the substantive and institutional differences between the two Covenants are often characterized as reflecting political and ideological divisions between these groups of countries.'); LANDMAN, supra note 26 , at 6 ("While charting the genealogy of human rights, one accepts that there have been chronological generations of rights, but that in their current manifestation, such a history does not privilege one set of rights over another."); Roland Rich, The Right to Development: A Right of Peoples?, in THE RIGHTS OF PEOPLES, supra note 166, at 39, 41 (outlining the three generations of human rights as advanced by Karel Vasak, the former legal adviser of UNESCO).

249. See CrAvEN, supra note 206 , at 9 ("Western States . . asserted the priority of civil and political rights as being the foundation of liberty and democracy in the (free world."); DONNELLY, supra note 187 , at 27 "We should ... note that in some Western circles a lingering suspicion of economic and social rights persists."); Pierre Sané, Introduction to HUMAN RIGHTS IN EDUCATION, supra note 15, at 1, 1 ("Some states were of the opinion that civil and political rights were 'genuine' human rights and should be implemented immediately, while economic, social and cultural rights were considered to be merely goals to be achieved progressively."); Coombe, Intellectual Property, supra note 23, at 60 ("[E]conomic, social, and cultural rights have been juridically marginalized in comparison to civil and political rights, both in terms of the institutional frameworks developed for their implementation and in terms of their judicial interpretation."); Yu, Reconceptualizing Intellectual Property Interests, supra note 18, at 1148 ("D]uring the UDHR drafting process, many Western countries, in particular Britain and the United States, were reluctant to recognize economic, social, and cultural rights as human rights.").

250. See HELFER \& AUSTIN, supra note 19, at 14 ("The interface between human rights and intellectual property both accentuates and challenges the tensions between first and 
dition, because the protection of traditional knowledge and traditional cultural expressions will raise questions about group rights, ${ }^{251}$ a robust discourse on intellectual property and human rights will further invite researchers to take more seriously the third generation of human rights. In short, the debate on intellectual property and human rights will provide a rich discussion implicating human rights in all three generations and of all typescivil, political, economic, social, cultural, and collective.

The third contribution is that a robust debate on intellectual property and human rights will require scholars to determine whether they subscribe to a philosophical or positive conception of human rights. Richard Falk identified two schools of jurisprudence in this area:

The positivists consider the content of human rights to be determined by the texts agreed upon by states and embodied in valid treaties, or determined by obligatory state practice attaining the status of binding international custom. The naturalists, on the other hand, regard the content of human rights as principally based upon immutable values that endow standards and norms with a universal validity. ${ }^{252}$

While these two schools are not mutually exclusive, and commentators have chosen to discuss human rights based on both conceptions, the emphasis a researcher has will likely affect the outcome of his or her analysis.

Initially, scholars tackling issues at the intersection of intellectual property and human rights focused on the philosophical conception of human rights. Beginning two decades ago, however, the greater emphasis on the right to the protection of the moral and material interests resulting from intellectual production and the close analysis of related human rights documents have caused scholars to devote more attention to the positive conception of human rights. A better understanding of the differences between

second generation rights.").

251. See General Comment No. 17, supra note 8, ๆ 32 (noting that the protection of the scientific, literary, and artistic productions of indigenous peoples "might include the adoption of measures to recognize, register and protect the . . . collective authorship of indigenous peoples under national intellectual property rights regimes").

252. Richard Falk, Cultural Foundations for the International Protection of Human

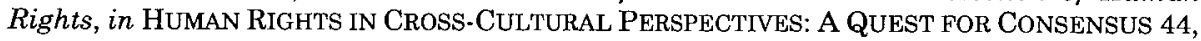
44 (Abdullahi Ahmed An-Na'im ed., 1992); see also THOMAs W. POGgE, WorLd POVERTY AND HUMAN RIGHTS: COSMOPOLITAN RESPONSIBLITIES AND REFORMS 59 (2d ed. 2008) (discussing the distinction between legal and moral human rights). 
these two rather distinct conceptions will enable scholars to closely examine the strengths and weaknesses of their chosen approach. While both approaches are equally defensible, and some commentators have combined them, ${ }^{253}$ it is important for researchers to recognize that the approach they choose may end up affecting the outcome of their analyses.

The fourth contribution is that a robust discourse on intellectual property and human rights will help explore whether the human rights system needs to be updated in light of the proliferation of new technologies. ${ }^{254}$ Thus far, many of the discussions in this area, such as those relating to the Internet, have raised questions of first impression about how to protect human rights in a changing technological environment. As European Parliamentarian Catherine Trautman asked in her foreword to the Research Handbook on $\mathrm{Hu}$ man Rights and Intellectual Property:

Does freedom of expression on the Internet constitute a new freedom or is this a new form of expression that should be included in the existing framework? Indeed, in the wake of the expansion of the digital environment, some have called for the creation of specific "fundamental digital rights". This idea of an "Internet Bill of Rights" was at the centre of many discussions in several Internet Governance Forums. 255

In addition, the growing use of Internet intermediaries and other emerging technology to monitor, filter, and censor communication has raised human rights challenges in Western democracies. ${ }^{256}$

253. See Yu, Methodological Reflections, supra note 30 (“[A] hybrid approach that starts with a positivist conception of human rights but is informed by a strong philosophical understanding is likely to be superior to either the positivist or philosophical approach alone.").

254. See Catherine Trautman, Foreword to RESEARCH HANDBOOK, supra note 20, at xii, xiii ("Many activists and lawyers tend to call for a 'digital review' of pre-existing human rights (and their application in courts).").

255. Id. at xii; see also Yu, Digital Copyright Enforcement Measures, supra note 24, at 457 ("[S]ome countries such as Costa Rica, France and Greece have recognized the right to the internet as a fundamental right. Finland and Spain have gone even further to mandate universal broadband access." (footnote omitted)).

256. See Rebecca Mackinnon, Consent of THE Networked: The Worldwide STRUGGLE FOR INTERNET FREEDOM 101 (2012) ("[P]oliticians throughout the democratic world are pushing for stronger censorship and surveillance by Internet companies to stop the theft of intellectual property. They are doing so in response to aggressive lobbying by powerful corporate constituents without adequate consideration of the consequences for civil liberties, and for democracy more broadly."); Yu, Digital Copyright Enforcement Measures, supra note 24 , at 462-67 (identifying the potential human rights threats posed by new digital copyright enforcement measures); Seth F. Kreimer, Censorship by Proxy: The First Amendment, Internet Intermediaries, and the Problem of the Weakest Link, 155 U. PA. L. 
The arrival of the debates on ubiquitous communication, synthetic biology, and artificial intelligence has also raised complicated questions about the essence of human rights protection in the twenty-first century. 257

Moreover, as Molly Land pointed out, the proliferation of new communications technologies and media platforms have provided individuals with the ability to utilize peer production to monitor human rights compliance. ${ }^{258}$ From a standpoint of human rights protection, such

[p]eer production would not only significantly augment our ability to identify, analyze, and respond to human rights violations in a timely and effective manner, but also increase the extent to which ordinary individuals connect to human rights issues, thus fostering the ability of the movement to mobilize broad constituencies and influence public opinion in support of human rights. ${ }^{259}$

A greater exploration of human rights protection along these new technological frontiers will therefore enhance our understanding of the interplay of human rights and new technologies. While issues relating to intellectual property and technology in the past

REV. 11 (2006) (discussing how private actors have been enlisted as "proxy censors" to control the flow of information); Peter K. Yu, Digital Copyright Reform and Legal Transplants in Hong Kong, 48 U. LOUISVILLE L. REV. 693, 715 (2010) (noting the free speech concerns raised by the proposal in Hong Kong's digital copyright reform to introduce a streamlined procedure to obtain users' information for the facilitation of copyright infringement actions); Yu, Nonmultilateral Era, supra note 23, at $1081 \mathrm{n} .174$ (noting that Internet service providers in many democracies in the developed world have now been used as gatekeepers to help censor digital content and restrict information flows); Peter K. Yu, The Graduated Response, 62 Fl.A. L. REV. 1373, 1402 (2010) (discussing how the graduated response system would undermine the protection of free speech, free press, and privacy).

257. See RASO ET AL., supra note 28 (evaluating the human rights impacts of uses of artificial intelligence). One emergent question that has serious implications in this area concerns whether machines could be, or should be, treated as humans for the purposes of determining authorship or inventorship. See, e.g., Ryan Abbott, Inventive Machines: Rethinking Invention and Patentability, in INTELLECTUAL PROPERTY AND DIGITAL TRADE IN THE AGE OF ARTIFICIAL INTElligence AND BIG Data 113, 117 (Xavier Seuba et al. eds., 2018) (arguing that "we should recognise computers as inventors").

258. See Molly Beutz Land, Peer Producing Human Rights, 46 Alberta L. Rev. 1115, 1117 (2009) [hereinafter Land, Peer Producing Human Rights] ("[T] here are many ways in which peer production might be used in conjunction with traditional reporting to achieve greater participation in the process of human rights advocacy."); see also Ben Wagner et al., Introduction to the Research Handbook on Human Rights and Digital Technology, in RESEARCH HANDBOOK ON DigitAL TECHNOLOGY, supra note 24, at 1, 3 (noting that "it is perfectly possible to engage with digital technologies and improve their contribution to human rights").

259. Land, Peer Producing Human Rights, supra note 258, at 1117. 
affected only a small group of individuals, such as authors and inventors, the rapid growth of technology and its widespread use have caused these issues to have a direct and ever-growing impact on virtually all individuals. ${ }^{260}$ In the twenty-first century, issues relating to intellectual property and technology will be important to anybody who seeks to properly function in society. ${ }^{261}$

\section{Interface Between the Two Regimes}

The previous two subparts have explored the contributions a robust discourse on intellectual property and human rights can provide to the intellectual property and human rights regimes, respectively. This subpart turns to those contributions that the discourse can offer to our ongoing efforts to examine the interface between the intellectual property and human rights regimes.

The first contribution is that, although human rights and intellectual property rights originate from two disparate international regimes, there is a growing need to understand the interplay between these two regimes. As the WTO Appellate Body reminded us in United States-Standards for Reformulated and Conventional Gasoline, "the General Agreement [which consists of the TRIPS Agreement and many other agreements] is not to be read in clinical isolation from public international law." ${ }^{62}$ Likewise, commentators have underscored the importance of studying the interface between different international systems. ${ }^{263}$

260. See Yu, Nonmultilateral Era, supra note 23, at 1059 ("Thanks to new technology and increased digital literacy, the ability to create today is no longer limited to a small subclass of 'intellectual workers' or 'creative laborers.' Instead, a growing number of individuals from both developed and less developed countries now have the ability to exploit their rights to the protection of the moral and material interests in intellectual creations.").

261. See Special Rapporteur's Report on the Right to Science, supra note 17, 119 ("[N]ew information communication technologies ... not only influence culture but are becoming an intrinsic part of culture as everyday practice.").

262. Appellate Body Report, United States-Standards for Reformulated and Conventional Gasoline, pt. III.B, WTO Doc. WT/DS2/AB/R (adopted Apr. 29, 1996).

263. See Sonja Bartsch et al., Interfaces: A Concept for the Analysis of Global Health Governance, in GLOBAL HEALTH GOVERNANCE AND THE FIGHT AGATNST HIV/AIDS 18 (Wolfgang Hein et al. eds., 2007) (advancing the concept and logic of "interfaces" for analyzing global governance); HELFER \& AUSTIN, supra note 19, at xiv (using "the term 'interface' ... to provide a structure for dialog and engagement between . . . two-hitherto largely separate-systems"); Peter K. Yu, Virotech Patents, Viropiracy, and Viral Sovereignty, 45 ARIZ. ST. L.J. 1563, 1622 (2013) ("As the discussion of global health governance becomes more 
The second contribution is that a close scrutiny of the interface between the intellectual property and human rights regimes has shown that human rights do not support all forms of intellectual property rights, or all aspects of each form of these rights. ${ }^{264}$ That human rights support only some forms or aspects of intellectual property rights while leaving others unsupported requires researchers to come up with innovative approaches to separate the different aspects of intellectual property rights, depending on whether they are supported by human rights.

In an earlier article, I proposed a structure to examine the different layers within a human rights framework for intellectual property: the production layer, the interest layer, the protection layer, and the limitation layer. ${ }^{265}$ While this structure was developed based on the texts of the UDHR, the ICESCR, General Comment Nos. 17 and 21, as well as other human rights instruments and documents, other ways can be developed to identify or separate the layers involved in the human rights framework. By correctly identifying and separating these layers, researchers will be able to develop appropriate treatments of the overlap between human rights and intellectual property rights.

The final contribution is that a deeper understanding of the interplay of intellectual property and human rights will help improve the coherence within the overall international economic system. ${ }^{266}$

inter-and multi-disciplinary, experts have begun to pay greater attention to the multifaceted interfaces between and among the different international regimes. These interfaces are not only present in places where the regimes intersect, but they can also be created through legal linkages, technical cooperation, institutional interplay, and political alliances." (footnote omitted)).

264. See supra note 227 and accompanying text (noting that human rights only support some forms or aspects of intellectual property rights).

265. See Yu, Anatomy, supra note 18, at 64-84 (advancing the proposal for the layered structure with illustrations regarding scientific publications, scientific innovations, scientific knowledge, and indigenous knowledge, innovations, and practices).

266. See ANDREW GOWERS, GOWERS REVIEW OF INTELLECTUAL PROPERTY 58 (2006) ("The IP rights available within the [United Kingdom] must be both internally and externally coherent. They must cover myriad ways in which knowledge is applied and ideas protected, and must also be integrated with other national and international systems of rights, particularly in light of globalisation."); Peter K. Yu, International Enclosure, the Regime Complex, and Intellectual Property Schizophrenia, 2007 MICH. ST. L. REV. 1, 18 ('Tn recent years, commentators and policymakers have begun to focus on the coherence of intellectual property policies, in addition to the maintenance of balance and flexibility in those policies."); Peter K. Yu, The Strategic and Discursive Contributions of the Max Planck Principles for Intellectual Property Provisions in Bilateral and Regional Agreements, 62 DRAKE L. REV. DISCOURSE 20, 24 (2014) (noting that "[i]n the past few years, commentators have widely 
Thanks to the marriage of intellectual property to trade through the adoption of the TRIPS Agreement, ${ }^{267}$ the intellectual property system has now become a major component of this larger system. As a result, intellectual property rules now form part of the governing rules. If systemic coherence is to be achieved, a greater linkage between intellectual property and human rights will be needed to minimize the tensions and conflicts between rules originating from the intellectual property system and those originating from either the human rights system or from other international regulatory systems. ${ }^{268}$

\section{RESPONSES TO SKEPTICS AND CRITICS}

Since the emergence of scholarship on intellectual property and human rights, commentators in the intellectual property field have questioned the overall benefits of a human rights discourse in the intellectual property area. In my earlier works, I have addressed three lines of criticisms-namely, (1) the "human rights" ratchet of intellectual property protection; (2) the undesirable capture of the human rights forum by intellectual property rights holders; and (3)

lamented the incoherence of the international intellectual property regime-or, more correctly, the 'international intellectual property regime complex"').

267. See generally DANIEL GERVAIS, THE TRIPS AGREEMENT: DRAFTING HISTORY AND ANALYSIS 3-27 (3d ed. 2008) (describing the origins and development of the TRIPS Agreement); JAYASHREE WATAL, INTELLECTUAL PROPERTY RIGHTS IN THE WTO AND DEVELOPING COUNTRIES 11-47 (2001) (recounting the negotiation process for the TRIPS Agreement); Peter K. Yu, TRIPs and Its Discontents, 10 MARQ. INTELL. ProP. L. REV. 369, 371-79 (2006) (examining four different accounts of the origins of the TRIPS Agreement).

268. Cf. SURYA P. SUBEDI, INTERNATIONAL INVESTMENT LAW: RECONCILING POLICY AND PRINCIPLE 158 (2d ed. 2012) ("Foreign investment law is . . . influenced by cross-fertilisation from other areas of public international law, especially those relating to human rights and environmental protection, as well as certain fundamental principles of international economic law such as the principle of economic self-determination of states, the right to develop, and the permanent sovereignty of states over their natural resources."); Cynthia M. Ho, $A$ Collision Course Between TRIPS Flexibilities and Investor-State Proceedings, 6 U.C. IRVINE L. REV. 395, 464 (2016) ("[]increased awareness and cross-fertilization in the investment arena of 'TRIPS norms would be desirable."); Peter K. Yu, Crossfertilizing ISDS with TRIPS, 49 LOY. U. CHI. L.J. 321, 358-59 (2017) (calling for the greater use of "crossfertilization to preempt the potential clash between [investor-state dispute settlement] and the WTO system"). Some commentators, however, are concerned about greater linkage, or cross-fertilization, between human rights and trade law. See Philip Alston, Resisting the Merger and Acquisition of Human Rights by Trade Law: A Reply to Petersmann, 13 EUR. J. INT'L L. 815, 815 (2002) (warning that "[Ernst-Ulrich] Petersmann's proposal for the enforcement of human rights through the WTO ... has a fundamentally different ideological underpinning from human rights law and would have extremely negative consequences for that body of law"). 
the framework's potential bias against non-Western cultures and traditional communities. ${ }^{269}$ As I elaborated on these concerns:

First, a greater emphasis on the human rights attributes of intellectual property rights could result in the undesirable elevation of the status of all attributes or forms of intellectual property rights to that of human rights, regardless of whether these attributes or forms have any human rights basis. Such elevation would exacerbate the already severe imbalance in the existing intellectual property system. Second, because rights holders and their supporting developed countries are rich, powerful, and organized, they may be able to capture the human rights forum to the detriment of less developed countries, traditional communities, and the disadvantaged. Such institutional capture would make the human rights forum less appealing for voicing concerns and grievances in the intellectual property area and for mobilizing resistance to increased intellectual property protection. Third, as the cultural relativism debate has shown, the existing human rights instruments may sit uneasily with countries and communities subscribing to non-Western cultures. Thus, a human rights discourse of intellectual property_or, more precisely, a discourse based on "Western" human rights-is likely to perpetuate the author-centered Western worldview that ignores important interests in non-Western countries and traditional communities. 270

This part does not seek to rehash my earlier responses. Instead, it addresses newer and more refined concerns of those skeptical or critical of the ongoing efforts to develop a robust discourse on intellectual property and human rights. Specifically, this part explores how such a discourse can benefit the future development of the intellectual property regime while addressing the needs and challenges of developing countries.

\section{A. Distractions from Internal Improvements}

One dominant strand of criticism from noted intellectual property scholars is that a robust discourse on intellectual property and human rights does not help generate the reform needed in the intellectual property area, such as the development of new limitations and exceptions to intellectual property rights or the redesign of the entire intellectual property or innovation system. In fact, a

269. For these earlier discussions, see Peter K. Yu, Challenges to the Development of a Human Rights Framework for Intellectual Property, in INTELLECTUAL PROPERTY LAW AND HUMAN RIGHTS, supra note 20, at 87; Yu, Reconceptualizing Intellectual Property Interests, supra note 18 , at $1123-48$.

270. Yu, Reconceptualizing Intellectual Property Interests, supra note 18, at 1124. 
greater focus on this discourse could undermine such development by taking away the time, energy, and effort needed to develop scholarship and policy analysis in the intellectual property area. ${ }^{271}$

For example, such a focus may create disruptions to the existing innovation system by fostering doctrinal incoherence, ${ }^{272}$ promoting uncertainty, ${ }^{273}$ and inviting unproductive confrontation. ${ }^{274}$ That fo-

271. See Mylly, supra note 98, at 104 ("[]ncreasing invocations of fundamental rights arguments in IP contexts could focus our attention away from the broader problematic developments of IP law. It is such developments that create the need to adjust the exclusive rights in the first place. According to a popular argument, we should concentrate on the proper inner limits of IP and its unjustifiable general developments.").

272. See Helfer, Mapping the Interface, supra note 98, at 9 ("Anxiety about the fragmentation of international law and the resulting uncertainty for state's legal obligations are [another] reason invoked for keeping human rights and IP apart."); HELFER \& AUSTIN, su. pra note 19, at 505 ("[Another] explanation for resistance to the human rights-intellectual property interface stems from a concern with fragmentation of international regimes, overlapping competencies of international institutions, and conflicts among legal obligations."); Raustiala, supra note 74, at 1027-28 (noting the occurrence of strategic inconsistencies "when actors deliberately seek to create inconsistency via a new rule crafted in another forum in an effort to alter or put pressure on an earlier rule").

273. As Rochelle Dreyfuss lamented:

Instead of relying on legislatures and courts to wield well-understood tools embedded in existing patent law, ad hoc rights-balancing leads to unpredictable decision-making. The result, ironically, is an environment less conducive to decisions to invest time and money in intellectual efforts. The new-human rights-justification can, in short, thwart the traditional-utilitarian - goal of limiting protection from free riders as a means of encouraging the advancement of knowledge.

Dreyfuss, supra note 208, at 74 .

274. As Professor Dreyfuss observed:

$[\Pi \mathrm{t}$ is hard to see how a rights discourse illuminates decisions on restructuring the patent system. Instead of highlighting concerns that ought to be taken into account, rights talk creates an adversarial climate in which each side ups the ante, further limiting access to important developments and interfering with the proper operation of the system as a whole. Indeed, the real paradox appears to be the following: While the new discourse attempts to help the marginalized, its consequence is double-marginalization-prices go up and output goes down as each right holder seeks to maximize its individual return. A utilitarian perspective allows policy makers to use the ample arsenal of available tools to make law responsive to changes in innovation and to align the system with other social interests, including but not limited to ones that are deemed fundamental.

Id. at 94 (footnote omitted); see also Helfer, Mapping the Interface, supra note 98, at 9 ("[T]o label something as a human right implies a rhetoric of absolutes and unconditional entitlements that is ill-suited to the rapidly changing technological and economic landscape in which IP rules operate."). 
cus may also undermine those intellectual property rights that human rights have supported. ${ }^{275}$ Indeed, a greater focus in this direction may even create the false hope of locating a more promising approach to help developing countries strike a better balance in the international intellectual property system. To many of these skeptics and critics, reform efforts that are endogenous to the intellectual property system are likely to be more promising than those that are exogenous to the system.

While I am sympathetic to this line of criticism, or at least skepticism, I hold a different perspective and offer three responses. The first response is that the efforts to strengthen and refine the discourse on intellectual property and human rights do not always compete in a zero-sum manner with efforts to undertake reform in the intellectual property area. While many policymakers and commentators will be interested in the latter, others will be interested in the former, or both the former and the latter. In the past three decades, we have seen an increasingly sophisticated intellectual property debate generated by the greater linkage between intellectual property rights and other areas, such as public international law, international trade, or investment law. ${ }^{276}$ Such linkage has also brought to the debate new organizations, policymakers, and

275. See Dreyfuss, supra note 208, at 74 ("Presumably, human rights can be outweighed only by other human rights. Accordingly, under a human rights approach, the benefit stream flowing from inventive production can be distributed, without a patentee's authorization, only to meet social needs that are likewise classified as fundamental."); see also Yu, Ten Common Questions, supra note 227, at 712 ("[T] property rights that do not have a human rights basis are likely to be deemed less important through a human rights lens.").

276. As I noted in an earlier article:

[The recent developments concerning investor-state dispute settlement] have created a general impression that investment law has now rudely entered the intellectual property domain. Such an intrusion is important because [investor-state] arbitrations involving intellectual property disputes represent "not only a new frontier in investment arbitration, but more importantly, uncharted territory in the increasingly complex and contested landscape of international intellectual property obligations." There has also been a growing concern about an ongoing shift of intellectual property norm-setting activities from the trade regime to the investment regime. Such a shift could take away the traditional limitations, safeguards, and flexibilities that have been built into the international intellectual property regime.

Peter K. Yu, The Investment-Related Aspects of Intellectual Property Rights, 66 AM. U. L. REV. 829, 835 (2017) [hereinafter Yu, Investment-Related Aspects] (footnotes omitted) (quoting Ruth L. Okediji, Is Intellectual Property "Investment"? Eli Lilly v. Canada and the International Intellectual Property System, 35 U. PA. J. INT'L L. 1121, 1122 (2014)). 
commentators, including those who do not have traditional expertise in the intellectual property area. ${ }^{277}$

To be sure, the arrival of trade discussions has created an unhealthy gloss that disturbs law and policy analysis in the intellectual property area. ${ }^{278}$ This distortion, however, is not the automatic result of the greater linkage between intellectual property and trade. Rather, the distortion largely originates from a narrow emphasis on profit maximization-an emphasis that privileges trade over the social function of intellectual property rights. ${ }^{279}$

277. See Peter K. Yu, Intellectual Property Training and Education for Development, 28 AM. U. INT'L L. REV. 311, 328 (2012) ("[B]ecause of the ever-expanding scope of intellectual property rights and the ability for these rights to spill over into other areas of international regulation, intellectual property training and educational programs should feature interand multi-disciplinary perspectives. Many of the existing programs focus primarily on the legal aspects of intellectual property. However, it is increasingly important to consider other aspects of intellectual property, such as political, economic, social, and cultural." (footnote omitted)); Peter K. Yu, Teaching International Intellectual Property Law, 52 ST. LouIS U. L.J. 923, 940 (2008) ('Whether one likes it or not, the 'law and . . ' movement has finally spread to international intellectual property law, and the subject has become increasingly multidisciplinary.").

278. See infra note 282 (collecting sources that discuss this unhealthy trade gloss).

279. As Farida Shaheed, the Special Rapporteur in the Field of Cultural Rights, declared:

The human rights perspective focuses attention on important themes that may be lost when copyright is treated primarily in terms of trade: the social function and human dimension of intellectual property, the public interests at stake, the importance of transparency and public participation in policymaking, the need to design copyright rules to genuinely benefit human authors, the im. portance of broad diffusion and cultural freedom, the importance of not-forprofit cultural production and innovation, and the special consideration for the impact of copyright law upon marginalised or vulnerable groups.

Special Rapporteur's Report on Copyright Policy, supra note 17, ๆ 90; see also Sisule F. Musungu, Rethinking Innovation, Development and Intellectual Property in the UN: WIPO and Beyond 4-5 (Quaker Int'l Affairs Programme, Ottawa, TRIPS Issues Paper No. 5, 2005) ("So far the only widely accepted notion has been that intellectual property is trade-related, justifying the TRIPS Agreement in the WTO but not the notion that intellectual property rules are also education-related, health-related, defence-related and environment-related and so forth."); Yu, Reconceptualizing Intellectual Property Interests, supra note 18, at 1137 ("Today, the development of intellectual property laws and policies is no longer just about intellectual creations; it has, indeed, affected many areas that are related to other human rights, including agriculture, health, the environment, education, culture, free speech, privacy, and democracy."). As the CESCR reminded us:

Ultimately, intellectual property is a social product and has a social function. States parties thus have a duty to prevent unreasonably high costs for access to essential medicines, plant seeds or other means of food production, or for schoolbooks and learning materials, from undermining the rights of large segments of the population to health, food and education. Moreover, States parties should prevent the use of scientific and technical progress for purposes con- 
Moreover, there can be quite some synergy between efforts to strengthen the discourse on intellectual property and human rights and efforts to reform the intellectual property system. In the past two decades, commentators have identified the different ways to use human rights to justify the introduction of new limitations and exceptions to intellectual property rights. The Marrakesh Treaty, for instance, has become the first WIPO agreement to explicitly state the interrelationship between the intellectual property system and international human rights instruments. ${ }^{280}$ In my earlier works, I have also highlighted the benefits of providing human rights-based compulsory licenses. ${ }^{281}$

The second response is that the past two decades have already seen developments in trade, investment, and other areas rudely intruding into the intellectual property policy space. The marriage of intellectual property with international trade through the adoption of the TRIPS Agreement has brought to the field unwanted

trary to human rights and dignity, including the rights to life, health and privacy, e.g. by excluding inventions from patentability whenever their commercialization would jeopardize the full realization of these rights. States parties should, in particular, consider to what extent the patenting of the human body and its parts would affect their obligations under the Covenant or under other relevant international human rights instruments. States parties should also consider undertaking human rights impact assessments prior to the adoption and after a period of implementation of legislation for the protection of the moral and material interests resulting from one's scientific, literary or artistic productions.

General Comment No. 17, supra note 8, ๆ 35 (footnotes omitted).

280. See Marrakesh Treaty, supra note 90, pmbl., recital 1 ("Recalling the principles of non-discrimination, equal opportunity, accessibility and full and effective participation and inclusion in society, proclaimed in the Universal Declaration of Human Rights and the United Nations Convention on the Rights of Persons with Disabilities."); see also Helfer, Conflict or Coexistence?, supra note 56, at 50 ("No references to human rights appear in the major intellectual property treaties such as the Paris and Berne Conventions, or in the more recently adopted TRIPS Agreement.").

281. See Yu, Reconceptualizing Intellectual Property Interests, supra note 18, at 1096-99 (discussing the provision of human rights-based compulsory licenses); see also Special Rapporteur's Report on the Right to Science, supra note 17, I 72 (discussing the use of "socially responsible" or "humanitarian" licensing to "ensure] that the licensing of intellectual assets, often developed by Government-funded research at universities, is negotiated and transacted in a manner conducive to providing broad affordable access to disadvantaged sections of society, particularly in developing countries"); Alan B. Bennett, Reservation of Rights for Humanitarian Uses, in 1 INTELLECTUAL PROPERTY MANAGEMENT IN HEALTH AND AGRICULTURE INNOVATION 41, 41 (Anatole Krattiger et al. eds., 2007) (discussing ways to reserve rights to meet the needs of developing countries for other humanitarian purposes); MAHOP, supra note 23, at 117-57 (proposing a framework of intellectual property-based, but human rights-oriented biodiversity regulatory measures); Joshua D. Sarnoff, The Patent System and Climate Change, 16 VA. J.L. \& TECH. 301, 350-51 (2011) (discussing "humanitarian licensing"). 
distortions when intellectual property rights are interpreted with a heavy trade gloss. ${ }^{282}$ The recent efforts by Philip Morris, Eli Lilly, and Bridgestone to use the investor-state dispute mechanism to address their intellectual property disputes with host states have also raised fears about the intrusion of investment law into the intellectual property policy space. ${ }^{283}$

In fact, after three decades of interactions between the intellectual property system and other international regulatory systems, it may be just too late to erect a "firewall" to preserve the purity of the intellectual property system. ${ }^{284}$ Instead, a more realistic approach is to develop ways to minimize the interferences posed by other international regulatory systems, ${ }^{285}$ or to establish new rules of engagement to address the interplay of different international regulatory systems. ${ }^{286}$ As far as this interplay is concerned, it will be highly worthwhile to explore why trade and investment have

282. See Daniel J. Gervais, How Intellectual Property and Human Rights Can Live Together: An Updated Perspective, in INTELLECTUAL PROPERTY LAW AND HUMAN RIGHTS, supra note 20, at 3, 12 ("Exceptions to copyright are seen through a trade-related effects-based prism."); Ruth L. Okediji, Public Welfare and the Role of the WTO: Reconsidering the TRIPS Agreement, 17 EMORY INT'L L. REV. 819, 914-15 (2003) (expressing disappointment that WTO panels, despite focusing on the purpose and objective of the TRIPS Agreement and the context of the negotiations, "have interpreted the provisions almost solely in light of the economic expectations of the private right holders"); Yu, Nonmultilateral Era, supra note 23 , at $1083-84$ (noting that the views taken by intellectual property rights holders and their supportive governments "are often colored by the trade-based-and at times, trade-onlyapproach developed through the founding of the WTO and the adoption of the TRIPS Agreement").

283. For this author's discussions of the interplay of investment and intellectual property, see Peter K. Yu, Conceptual and Institutional Improvements in Investor-State Dispute Settlement, in RESEARCH HANDBOOK ON INTELLECTUAL ProperTy AND INVESTMENT LAW (Christophe Geiger ed., forthcoming 2019); Peter K. Yu, Investor-State Dispute Settlement and the Trans-Pacific Partnership, in INTELLECTUAL PROPERTY AND THE JUDICIARY 463 (Christophe Geiger et al. eds., 2018); Peter K. Yu, The Pathways of Multinational Intellectual Property Dispute Settlement, in INTELlectual ProperTy AS ProperTy: OF PHARMACEUTICALS, TOBACCO, Commodities AND OTHER MATTERS (Christopher Heath \& Anselm Kamperman Sanders eds., forthcoming 2019); Yu, Crossfertilizing ISDS with TRIPS, supra note 268; Yu, Investment-Related Aspects, supra note 276.

284. See HELFER \& AUSTIN, supra note 19, at 503 (rejecting, as a matter of both principle and practical politics, "arguments for maintaining a firewall between the [intellectual property and human rights] regimes and avoiding the difficult work of normative engagement").

285. See supra note 266 (collecting sources that discuss the need for coherence in domestic and international intellectual property laws).

286. See Peter K. Yu. The Second Transformation of the International Intellectual Property Regime, in CONSTITUTIONAL HEDGES OF INTELLECTUAL PROPERTY (Jonathan Griffiths \& Tuomas Mylly eds., forthcoming 2019) (calling for the establishment of these rules). 
managed to rudely enter and stay behind in the intellectual property policy space while human rights have not succeeded to the same extent.

The third response is that human rights, as noted earlier, have provided the much-needed help to push for greater intellectual property reforms at the international level. There is no denying that the emphasis on the threats posed by the TRIPS Agreement to the protection of the right to life and the right to health has generated considerable support for new human rights developments, ${ }^{287}$ which range from the U.N. Sub-Commission's adoption of Resolutions 2000/7 and 2001/21288 to the OHCHR's critique of the TRIPS Agreement 289 to other efforts relating to the Doha Declaration on the TRIPS Agreement and Public Health. ${ }^{290}$ The human rights of those with print disabilities have also played an important role in the negotiation, adoption, and the eventual entering into force of the Marrakesh Treaty. ${ }^{291}$

To be sure, there are still fears that a greater emphasis on individual rights - in particular, the right to property ${ }^{292}$ - will lead to distortions that favor individual authorial interests and those industries and governments that benefit from greater protection of such interests. Nevertheless, these fears should be addressed by developing a more sophisticated understanding of the interrelationship between intellectual property and human rights and a more pluralistic interpretation of human rights. They should not be addressed by ignoring the debate on intellectual property and human rights. 293

287. See supra note 219 (collecting sources that examine the impact of the right to health on intellectual property developments).

288. Res. 2001/21, supra note 7; Res. 2000/7, supra note 7.

289. High Commissioner's Report, supra note 43.

290. World Trade Organization, Declaration on the TRIPS Agreement and Public Health, W'TO Doc. WT/MIN(01)/DEC/2 (2001), 41 I.L.M. 755 (2002).

291. Marrakesh Treaty, supra note 90.

292. See Yu, Anatomy, supra note 18, at 85-95 (discussing the growing use of the right to property to provide an alternative human rights basis for intellectual property rights and addressing the related concerns).

293. As I noted in an earlier article:

While [the concerns about the adverse impact of the linkage between intellectual property and human rights] are valid and important, the best response to alleviate these concerns is not to dissociate intellectual property rights from human rights or to cover up the fact that some attributes of intellectual property rights are, indeed, protected in international or regional human rights 


\section{B. Lack of Benefits to Developing Countries}

A growing strand of criticism that deserves some response pertains to whether a robust discourse on intellectual property and human rights can benefit developing countries. In a recent article, Ruth Okediji expressed reservation about the use of the human rights frame to promote development in the intellectual property area, pleading for "caution about the contemporary construction of the IP/human rights interface and its sanguine embrace by wellmeaning scholars and policymakers alike." 294 As she elaborated:

The human rights framework is problematic for the development interests and aspirations of most people living in the Global South. [My] skepticism first grew out of concern about the strongly individualistic focus of human rights - both in its ideological orientation towards western liberal tradition and in its reliance of human rights normsetting institutions on external constituencies for expertise and guidance. At least in the field of IP, those constituencies usually comprise international non-governmental organizations that, while well-meaning, stymie the necessary domestic debate that is a precursor for the development of local actors who can more ably challenge the structural challenges imposed by international IP regimes. The human rights discourse certainly provides important grist for the international debate over global IP norms, but it accomplishes remarkably little on the domestic front. Given the outsized role of international IP in global development, it is unsurprising that IP has played a similarly outsized role in human rights. The instinctive fidelity of relevant UN institutions and processes to a narrative that casts IP as an indispensable hero in the struggle for development in the Global South creates significant challenges for the promise of a redemptive effect of human rights arguments on local IP reform initiatives. ${ }^{295}$

Professor Okediji is not only a preeminent scholar in international intellectual property law, but also one of the rare few who linked intellectual property to human rights before the historic

instruments. Rather, it is important to clearly delineate which attributes of intellectual property rights would qualify as human rights and which attributes or forms of those rights should be subordinated to human rights obligations due to their lack of any human right basis. In doing so, a human rights framework will highlight the moral and material interests of individual authors and inventors while exposing the danger of increased expansion of those attributes or forms of intellectual property rights that have no human rights basis.

Yu, Reconceptualizing Intellectual Property Interests, supra note 18, at 1128.

294. Okediji, Human Rights, supra note 219, at 4.

295. Id. (footnote omitted). 
WIPO-OHCHR panel on "Intellectual Property and Human Rights." 296 She was also the lead negotiator for Nigeria at the WIPO diplomatic conference that concluded the Marrakesh Treaty. ${ }^{297}$ Her view on this debate therefore deserves close examination.

Professor Okediji's main concern with having a human rights discourse in the intellectual property area is threefold. First, that discourse narrowly emphasizes individual rights-or, worse, civil and political rights as recognized in the Western liberal tradition. This critique resembles the earlier critiques about the "human rights" ratchet of intellectual property protection ${ }^{298}$ and the human rights system's potential bias against non-Western cultures and traditional communities. ${ }^{299}$

Second, she made an important claim that the balance demanded by international and regional human rights instruments will not necessarily provide the balance needed in the intellectual property system to move developing countries forward. As Professor Okediji observed:

Intellectual property doctrines that are primarily intended to balance the interests of individual authors and users are ill-suited to address the collective interest in, and need for, consistent and effective access to knowledge goods. At a minimum, different kinds of limitations and exceptions to IP rights are needed. An appropriately conceived IP/human rights interface requires international legal recognition not just of an obligation to have the right kind of national IP policy, but the freedom and obligation to implement such a policy for the collective good. In sum, the call for balance reflected in General Comment 17 and in the IP/human rights literature unhelpfully substitutes the internally required balance of IP rights considering the collective with what human rights law requires of states in pursuit of the highest ideals of human flourishing. 300

296. See Gana, supra note 35 (providing a rare engagement with the debate on intellectual property and human rights in 1996).

297. Ruth L. Okediji: Biography, HARV. L. SCH., https://hls.harvard.edu/faculty/direct ory/11409/Okediji [https://perma.cc/Y94A-G5VW] (last visited Apr. 1, 2019).

298. See Yu, Reconceptualizing Intellectual Property Interests, supra note 18, at 1124-33 (responding to criticisms concerning the "human rights" ratchet of intellectual property protection).

299. See id. at 1141-48 (responding to criticisms concerning the human rights system's potential bias against non-Western cultures and traditional communities).

300. Okediji, Human Rights, supra note 219, at 35-36 (footnote omitted); see also Ruth L. Okediji, Securing Intellectual Property Objectives: New Approaches to Human Rights Considerations, in CASTING THE NET WIDER: HUMAN RIGHTS, DEVELOPMENT AND NEW DUTY- 
In her view, if developing countries are to catch up with their more developed counterparts, they will need to develop an appropriate intellectual system that is well tailored to their specific needs, interests, conditions, and priorities. They may even have to decide for themselves what innovation system they need and what role intellectual property rights will play as part of this larger system. ${ }^{301}$

Finally, she was concerned about the persistent institutional weakness found in many developing countries. As she explained:

[T] he IP/human rights interface is preoccupied with establishing flexibilities to the IP system, such as the Bolar exception in patent law, the legitimacy of compulsory licenses, or fair use and other limitations and exceptions in copyright law. Limitations and exceptions require institutions-relatively sophisticated institutions-to effectively apply and enforce limits on IP. In least-developed countries, such institutions are lacking or are insufficiently mature to deploy existing limitations and exceptions-much less creatively assert new ones within the unsettled context of international IP laws. Moreover, if all that the IP/human rights interface produces are outcomes that could be achieved without resorting to human rights, it is difficult to justify the need to resort to human right frameworks in the first place. ${ }^{302}$

Interestingly, even though Professor Okediji was skeptical of the success of using the human rights frame to generate the intellectual property reforms needed in developing countries, her recom-

BEARERS 211, 242 (Margot E. Salomon et al. eds., 2007) ("The primary utility of human rights in the development discourse relating to intellectual property should be to preserve and promote intellectual property's core balance-not replace it.").

301. As Professor Okediji explained:

The quest for balance or reconciliation that permeates the IP/human rights literature reflects an implicit assumption-or acceptance of the assumptionthat IP rights are optimal means to advance human development in a globalized world. With the premise that the two regimes are formal equals, ... the discourse of reconciliation reinforces the legitimacy of the current version of $I P$ rights and fosters acceptance of the idea that IP and human rights are justifiably in a competitive jostle over which should prevail as the dominant paradigm for promoting human welfare.

Okediji, Human Rights, supra note 219, at 27; see also Okediji, Limits of Development Strategies, supra note 236 , at 364 ("[S]elf-determination ... offers a context in which the sovereign obligation to steward development would justify-perhaps demand-that a state devise a means to encourage innovation, which is a proven factor in economic growth. ... [S]elfdetermination would also police the boundaries of that stewardship by legitimizing interand intra-TRIPS efforts to ensure the appropriate level of protection to secure incentives to create, use and adapt technology locally.").

302. Okediji, Human Rights, supra note 219 , at 60 . 
mendation is not to refrain from engaging in human rights discussions in the intellectual property area. Rather, she underscored the need to emphasize those aspects of human rights that are outside the Western liberal tradition, such as collective rights and the right to development. ${ }^{303}$ As she declared:

[C]onsideration of the IP/human rights interface must extend beyond discussion of the IP rights currently recognized in international human rights instruments and embrace possibilities for IP reform that could emerge from a serious engagement with a panoply of economic, social, cultural, and group rights. It is these rights . . that will most deeply and genuinely inform meaningful prospects for human and economic development. ${ }^{304}$

To some extent, her critique of the efforts to engage in a human rights discourse in the intellectual property area resembles a critique of the flaws in, and the misguided development of, the existing international human rights system. In her view, the system is flawed for three reasons:

First, a human rights framework for IP does not ineluctably facilitate socially desirable outcomes for all countries; slapping human rights ideals on IP regimes can, instead, actually strengthen IP rights in socially harmful ways. Second, human rights-driven responses to the serious global challenges exacerbated by an outsized global IP system are not neutral. To the extent human rights objectives impose important limits on the domestic exercise of IP rights, that progress occurs principally in developed countries. In multilateral arenas where norm-setting agendas are fixed, the most successful IP-related human rights arguments are those that resonate predominantly in the western liberal tradition or that build on the IP jurisprudence of U.S. and European courts. Other than where the right to health is involved, concerns that implicate the values and institutions of leading developed countries frequently drive human rights advocacy for IP reform. Third, and most significant, the limited effect of the human rights framework on the IP/human rights interface is attributable to the narrow vision of human rights that has long dominated the discourseone that excludes economic, social, and cultural rights. ${ }^{305}$

303. See id. at 31 ("Group economic, social, and cultural rights must assume a far greater role in human rights frameworks directed at international IP law and policymaking."); see also Abdel-Latif, supra note 93, at 605 (lamenting that "the right to development . . . has been conspicuously absent from th[e] growing interest in the human rights and IP interface").

304. Okediji, Human Rights, supra note 219, at 9-10.

305. Id. at 4-5 (footnotes omitted). 
According to Professor Okediji, the human rights frame will provide limited assistance to developing countries not because a human rights frame cannot help these countries, but because the existing human rights system privileges interests among developed countries and within the Western liberal tradition at the expense of those in the developing world.

This distinction is important because a greater understanding of the methods and methodology used to conduct research on intellectual property and human rights will help us determine whether our preferred approach will perpetuate the flaws in the existing international human rights system. An enhanced understanding will also help us design a more appropriate human rights framework for intellectual property law and policy to address the needs and interests of developing countries. Achieving the latter is indeed one of the reasons why scholars should devote more attention to the debate on intellectual property and human rights in the first place.

\section{CONCLUSION}

When the TRIPS Agreement was adopted in April 1994, few scholars paid attention to the human rights implications of intellectual property protection. If discussion arose, its focus tended to center around development goals, basic human needs, or other abstract issues. ${ }^{306}$ Today, however, international organizations and academic scholars have undertaken a more systematic analysis of issues lying at the intersection of intellectual property and human rights. This "systematic turn" is due in no small part to the contributions academic commentators have made in this area in the past two decades.

While it will still be worthwhile to engage in scholarship that aims to clarify the scope, content, and obligations concerning the right to the protection of the interests resulting from intellectual production, or to address the potential tensions and conflicts between human rights and intellectual property rights, much of this research has been completed admirably by the first generation of

306. See, e.g., Gana, supra note 35 (discussing ways to reconcile intellectual property rights with the development process and human rights protection in precapitalist, preindustrial countries). 
intellectual property and human rights scholars. To further advance the academic discourse, scholars in this area should start thinking more deeply about the research and interpretive methods used to advance the promotion and protection of human rights in the intellectual property area. ${ }^{307}$

Fortunately, the recent emergence of a slowly growing volume of literature on human rights methods and methodology has provided important insights into how scholars can upgrade the debate on intellectual property and human rights. This article not only invites scholars to take a methodological turn, but also explains why a robust discourse on intellectual property and human rights will provide significant benefits to both the intellectual property and human rights regimes. It is my hope that this discourse will help take the debate on intellectual property and human rights to the next level as we commemorate the seventieth anniversary of the UDHR and celebrate the more than two decades of scholarship in this intersectional area. information have become more robust, the human rights community needs to continue to improve the degree to which it monitors, measures and analyses human rights."). 
$* * *$ 